\title{
Estudo do papel da Spartina alterniflora como espécie bioindicadora de contaminação por elementos traço no Complexo Estuarino-Lagunar de Cananéia-Iguape (SP)
}

Dissertação apresentada ao Instituto Oceanográfico da Universidade de São Paulo como parte dos requisitos para a obtenção do título de Mestre em Ciências, área de Oceanografia Química e Geológica.

Orientadora:

Profa Dra Elisabete de Santis Braga da Graça Saraiva

SÃO PAULO

2011 
UNIVERSIDADE DE SÃO PAULO

INSTITUTO OCEANOGRÁFICO

\section{Estudo do papel da Spartina alterniflora como espécie bioindicadora de contaminação por elementos traço no Complexo-Estuarino Lagunar de Cananéia-Iguape (SP)}

\section{CARLOS EDUARDO STEIN}

Dissertação de Mestrado apresentada ao Instituto Oceanográfico da Universidade de São Paulo como parte dos requisitos para a obtenção do título de Mestre em Ciências, área de Oceanografia Química e Geológica.

Julgada em

Prof(a). Dr(a).

Prof(a). Dr(a).

Prof(a). Dr(a). 
Às famílias Mattos e Stein.

Aprendendo sempre com o movimento da maré, ora em baixamar, ora em preamar. 


\section{AGRADECIMENTOS}

\section{À Deus.}

Aos meus pais Carlos Humberto e Heloisa pelo apoio incondicional.

À Érika pelo incentivo e companhia de trabalhos, estudos e moradia.

À Profa Elisabete pela oportunidade, confiança e orientação.

Aos colaboradores Mitiko Saiki, Pio Colepicolo e Déborah Fávaro.

Aos amigos LabNuts, Léo, Lívia, João, Esther, Samara e Ricardo por tudo e todo esse tempo de convivência.

Ao Grande Vitor Chio pelas consultorias químicas e demais ajudas em laboratório.

Aos estagiários LabNuts (Bia, Flávia, Vinicius, Fernanda, Silvana, Lucas, Thati, enfim todos os estagiários que são muitos) e em especial à Jujuuu que compartilhou os atolamentos no mangue, triturações da Spartina e suas loucas e divertidas conversas.

À Aline Martins pela companhia, troca de idéias e assessoria bioquímica Ao Renato Lahos, Léo, Lú, enfim, todos do LabPio.

À tripulação da embarcação Albacora II, Sérgio, Nhonhô, Humberto e ao Ulisses que ajudou bastante na coleta da grama.

Ao IBAMA que apoiou os trabalhos em Iguape e ao apoio dado pelo CNPq Proc $n^{\circ}$ 580303/2008-0. Aos projetos VAGRA-CNPq $n^{\circ} 552437 / 2007-7$ e ao INCT TMCOcean CNPq n573601/2008-9 que apoiaram esta pesquisa. 


\section{SUMÁRIO}

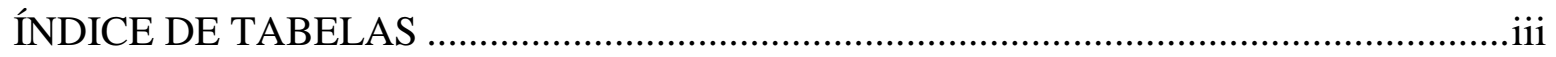

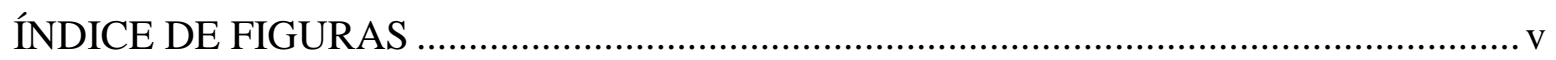

RESUMO …



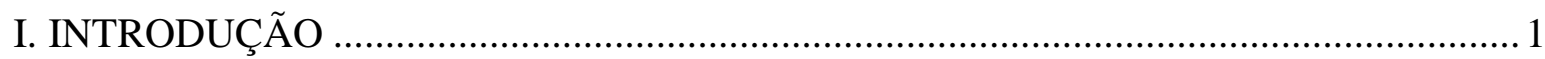

1. Complexo estuarino-lagunar de Cananéia-Iguape ........................................................... 1



3. Spartina como bioindicadora de contaminação por elementos traço …………………....5

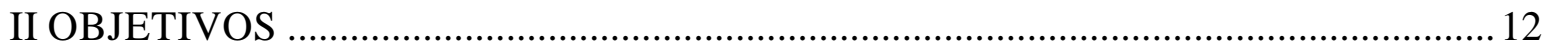

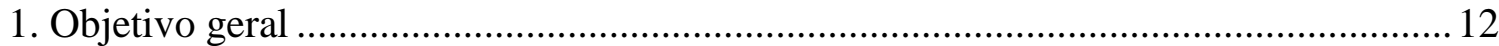

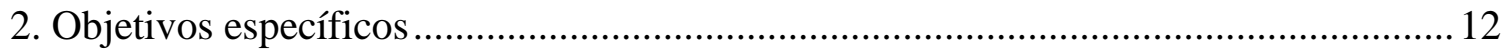

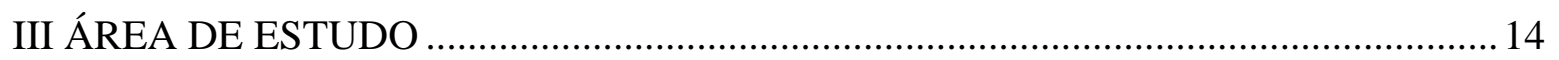





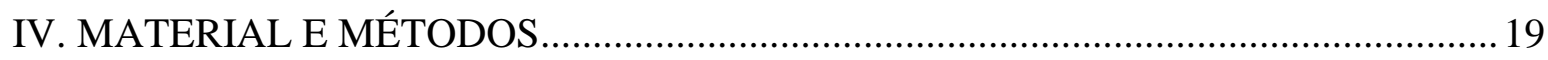

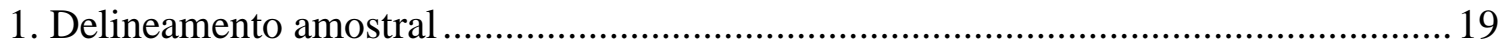

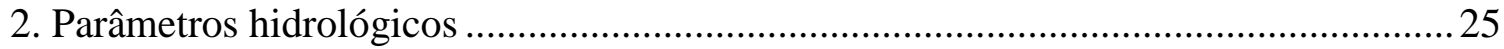

2.1 Maré

2.2 Temperatura

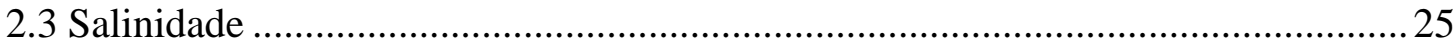

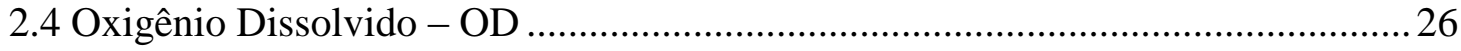

2.5 Potencial Hidrogeniônico - pH ..........................................................................26

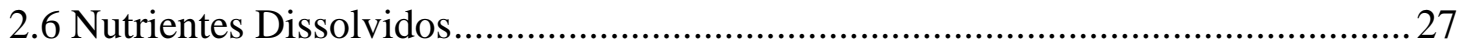

2.7 Material em suspensão (MES) e material orgânico em suspensão (MOS) ….........28

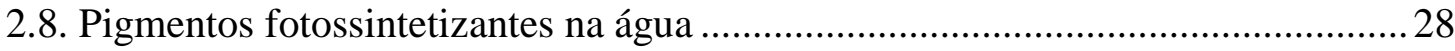

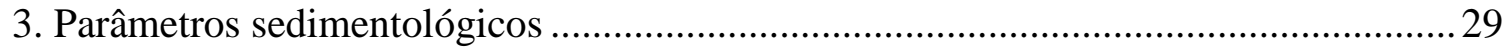

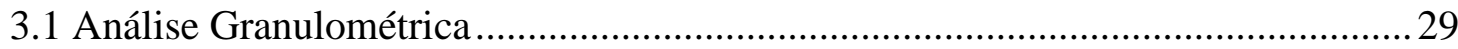

3.2 Análise de matéria orgânica e teores de carbonatos no sedimento.............................30



4.1 Caracterização dos Bancos de S. alterniflora .......................................................... 31

4.2 Determinação de clorofila-a em S. alterniflora ………………………………........ 32

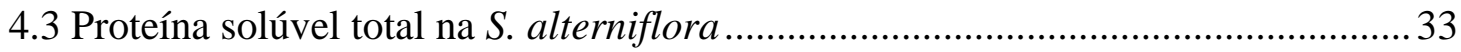

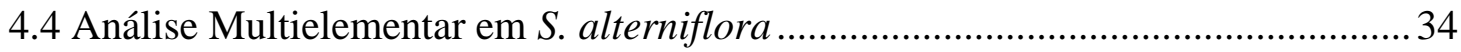

4.5 Determinação de $\mathrm{Hg}$, $\mathrm{Pb}$ e Cd em S. alterniflora …………………………….......... 38 
V. RESULTADOS E DISCUSSÃO..................................................................... 44



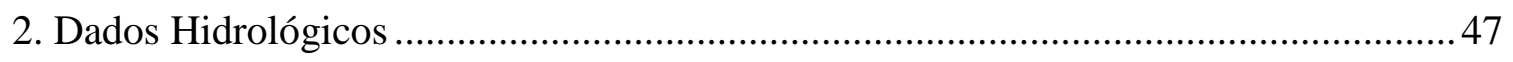

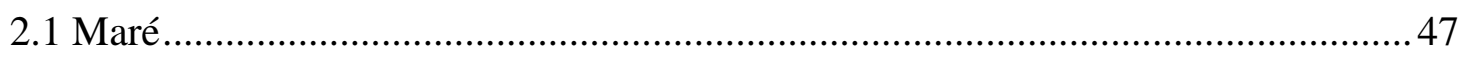

2.2 Dados hidrobioquímicos da água de superfície do corpo hídrico e da água adjacente aos campos de $S$. alterniflora nos dois setores do sistema .........................50

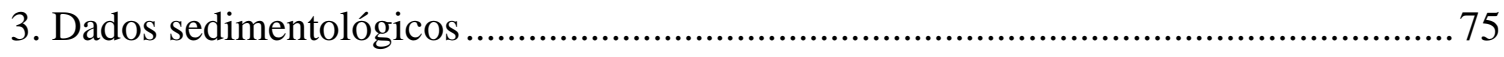



4.1 Caracterização dos Bancos de Spartina alterniflora ............................................ 85

4.2 Dados Multielementares em Spartina alterniflora ............................................. 94

4.3 Dados de $\mathrm{Hg}$, Cd e $\mathrm{Pb}$ em S. alteniflora ............................................................ 107

4.4 Avaliação de clorofila $a$ em $S$. alterniflora ..................................................... 113

4.5 Avaliação de Proteína Solúvel Total em Spartina alterniflora ........................... 119



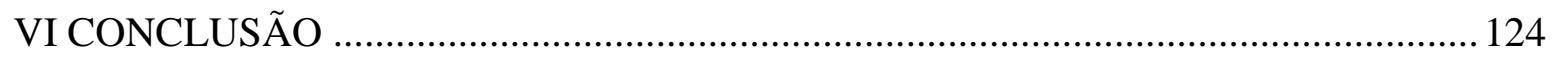

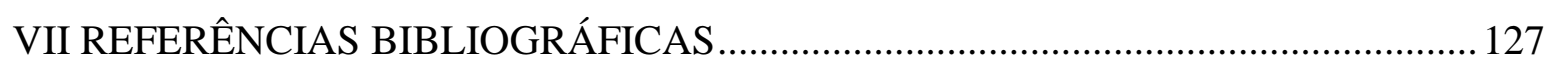




\section{ÍNDICE DE TABELAS}

Tabela 1: Denominação, distribuição e localização dos campos e quadrados amostradores da gramínea e das estações de coleta hidrogeoquímica, no período de Verão de 2009.

Tabela 2: Denominação, distribuição e localização dos campos e quadrados amostradores no período de Inverno, na região sul, Ponta do Arrozal e llha Comprida (Cananéia), no setor adjacente norte, o Mar Pequeno e a Barra de Icapara - Ilha Comprida. 23

Tabela 3. Denominação, distribuição e localização dos campos e quadrados amostradores no Verão de 2010, na região sul, Ponta do Arrozal e Ilha Comprida (Cananéia) e o setor norte, Barra do Icapara - Ilha Comprida. 24

Tabela 4: Valores dos materiais de referência certificados Peach Leaves (NIST SRM 1547) e Apple Leaves (NIST SEM 1515) e valores obtidos pela técnica de Espectrometria de Absorção Atômica para os elementos $\mathrm{Pb}, \mathrm{Hg}$ e Cd. 42

Tabela 5. Dados hidrobioquímicos da campanha de fevereiro de 2009 (verão), nos pontos dos setores norte e sul do complexo Estuarino-Lagunar Cananéia-Iguape e dos campos de S. alterniflora, sendo CH (corpo hídrico); PA (Ponta do Arrozal); MP (Mar pequeno); BI (Barra do Icapara). .52

Tabela 6. Dados hidrobioquímicos da campanha de agosto de 2009 (inverno), dos pontos dos setores norte e sul do complexo Estuarino-Lagunar Cananéia-Iguape e dos campos de S. alterniflora, sendo CH (corpo hídrico); PA (Ponta do Arrozal); MP (Mar Pequeno); BI (Barra do Icapara).

Tabela 7. Dados hidrobioquímicos da campanha de março de 2010 (verão), nos pontos dos setores norte e sul do complexo Estuarino-Lagunar Cananéia-Iguape e dos campos de S. alterniflora, sendo $\mathrm{CH}$ (corpo hídrico); PA (Ponta do Arrozal); MP (Mar pequeno); BI (Barra do Icapara). .71

Tabela 8. Dados da caracterização do sedimento superficial dos campos de $S$. alterniflora dos setores norte e sul do $\mathrm{CELCl}$ nos períodos de verão e inverno de 2009 e verão de 2010. .78

Tabela 9. Medidas biométricas de $S$. alterniflora obtidas em indivíduos coletados em quadrados, no período do Verão de 2009, nas regiões de Cananéia e Iguape.

.86

Tabela 10. Medidas biométricas de S. alterniflora obtidas em indivíduos coletados em quadrados (Q) no período de Inverno de 2009 nas regiões de Cananéia e Iguape.

Tabela 11. Medidas biométricas $S$. alterniflora obtidas em indivíduos coletados em quadrados, no período de Verão de 2010 nas regiões de Cananéia e Iguape....... 88

Tabela 12: Concentração dos elementos químicos encontradas nas partes aérea e subterrânea da $S$. alterniflora nas regiões de Cananéia e Iguape nos períodos de verão e inverno de 2009 e verão de 2010. 
Tabela 13: Concentrações de $\mathrm{Pb}, \mathrm{Cd}$ e $\mathrm{Hg}$ encontrados nas partes aérea e subterrânea da S. alterniflora nas regiões de Cananéia e Iguape. ........................... 108

Tabela 14. Matriz de correlação de componentes principais, parâmetros hidroquímicos: temperatura, salinidade, oxigênio dissolvido, $\mathrm{pH}$, material particulado em suspensão, \% matéria orgânica no particulado, silicato, fosfato, clorofila-a e feopigmento. 


\section{ÍNDICE DE FIGURAS}

Figura 1. Aspecto de um campo de Spartina alterniflora, Família Poaceae, Ordem Cyperales em Cananéia (SP). 4

Figura 2. Localização do Complexo Estuarino-Lagunar de Cananéia-Iguape. Setor norte, barra de Icapara, Ilha Comprida e a cidade de Iguape. Setor Sul, Ilha de Cananéia, Ilha do Cardoso e Ilha Comprida. 15

Figura 3. Canal artificial do Valo Grande, setor Sul, município de Iguape. Vista aérea da saída do rio Ribeira de Iguape ligando ao Mar Pequeno (a) e, divisão da Cidade e formação de ilhas no Mar Pequeno (b). 16

Figura 4. Área amostral do setor sul do complexo estuarino-lagunar de CananéiaIguape. Visualiza-se o Campo da Ponta do Arrozal (a) junto à llha de Cananéia e o Campo da ilha Comprida (b). Fonte: Google Earth. 20

Figura 5. Ponto amostral do setor adjacente norte do Complexo Estuarino-Lagunar de Cananéia-Iguape, campo localizado no Mar Pequeno. Fonte: Google Earth....21

Figura 6. Ponto amostral ao setor norte do Complexo Estuarino-Lagunar Cananéia-Iguape, próximo à Barra do Icapara. Fonte: Google Earth. ......................21

Figura 7: Quadrado amostrador de 35×35cm no campo de Spartina alterniflora...31

Figura 8: Medidas de comprimento e espessura da S. alterniflora............................. 32

Figura 9. Variações diárias de temperatura do $\operatorname{ar}\left({ }^{\circ} \mathrm{C}\right)$ e pluviosidade $(\mathrm{mm})$ nos períodos trabalhados, fevereiro de 2009 (a), agosto de 2009 (b) e fevereiro de 2010 (c) referente à estação meteorológica IOUSP da base de Cananéia.............. 46

Figura 10. Variação da altura de maré nos dias de coleta hidroquímica e nos momentos de coleta da Spartina alterniflora nas 3 campanhas: verão de 2009 (a); inverno de 2009 (b) e verão de 2010 (c). 48

Figura 11. Variação temporal dos parâmetros físicos e químicos ao longo de um período de maré (13h) no período do verão de 2009, nos dois setores, Cananéia (esquerda) e lguape (direita). ( $\bullet$ losango preto refere-se ao corpo hídrico nos dois

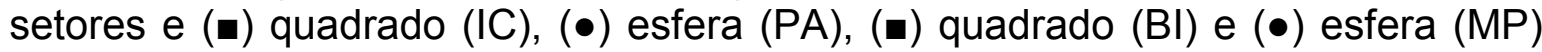
para os campos de $S$. alterniflora, .54

Figura 12: Variação temporal do silicato, fosfato, MPS e \%MOS ao longo de um ciclo de maré no período do verão de 2009, em dois setores, Cananéia (esquerda) e lguape (direita). Refere-se ao corpo hídrico $(\downarrow)$ losango preto para os dois setores, $(\bullet)$ quadrado $(\mathrm{IC}),(\bullet)$ esfera $(\mathrm{PA}),(\boldsymbol{\bullet})$ quadrado $(\mathrm{BI})$ e $(\bullet)$ esfera $(\mathrm{MP}) \ldots 57$

Figura 13. Variação temporal da clorofila a e feofitina ao longo de um ciclo de maré no período do verão de 2009 em dois setores, Cananéia (esquerda) e Iguape (direita). Refere-se ao corpo hídrico ( $\bullet$ losango preto para os dois setores,

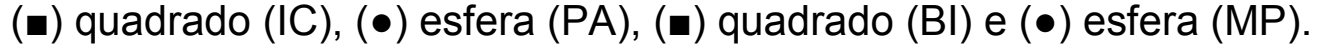
60

Figura 14. Variação temporal dos parâmetros físicos e químicos ao longo de um ciclo de maré no período do Inverno de 2009 nos dois setores, Cananéia 
(esquerda) e Iguape (direita). Refere-se ao corpo hídrico ( $\bullet$ losango preto para os dois setores, ( $\mathbf{\Delta})$ triangulo $(\mathrm{IC}),(\mathbf{\square})$ quadrado $(\mathrm{PA}),(\mathbf{\Delta})$ triangulo $(\mathrm{BI})$ e $(\mathbf{\square})$ quadrado (MP). 64

Figura 15. Variação temporal dos teores de silicato, fosfato, MPS e \%MOS ao longo de um ciclo de maré no período do inverno de 2009 em dois setores, Cananéia (esquerda) e Iguape (direita). Refere-se ao corpo hídrico $(\bullet)$ losango preto para os dois setores, ( $\mathbf{a})$ quadrado $(\mathrm{IC}),(\bullet)$ esfera $(\mathrm{PA}),(\boldsymbol{\bullet})$ quadrado $(\mathrm{BI})$ e $(\bullet)$ esfera (MP).

Figura 16. Variação temporal da clorofila a e feofitina ao longo de um ciclo de maré no período do inverno de 2009 em dois setores, Cananéia (esquerda) e Iguape (direita). Refere-se ao corpo hídrico $(\downarrow)$ losango preto para os dois setores,

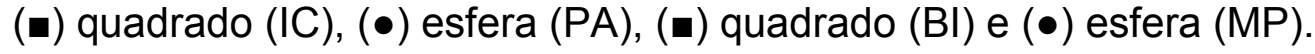
69

Figura 17. Variação temporal dos parâmetros físicos e químicos ao longo de um ciclo de maré no período de Verão de 2010 nos dois setores, Cananéia (esquerda) e Iguape (direita). Refere-se ao corpo hídrico ( $\$$ ) losango preto para os dois setores, $(\mathbf{\Delta})$ triangulo $(\mathrm{IC}),(\mathbf{\square})$ quadrado $(\mathrm{PA})$ e $(\mathbf{\Delta})$ triangulo $(\mathrm{BI})$..........................72

Figura 18. Variação temporal dos teores de silicato, fosfato, MPS e \%MOS ao longo de um ciclo de maré no período do verão de 2010 em dois setores, Cananéia (esquerda) e Iguape (direita). Refere-se ao corpo hídrico $(\bullet)$ losango preto para os dois setores, $(\boldsymbol{\bullet})$ quadrado $(\mathrm{IC}),(\bullet)$ esfera $(\mathrm{PA})$ e $(\mathbf{\bullet})$ quadrado $(\mathrm{BI})$.

Figura 19. Variação temporal da clorofila a e feofitina ao longo de um ciclo de maré no período do verão de 2010 em dois setores, Cananéia (esquerda) e Iguape (direita). Refere-se ao corpo hídrico ( $\bullet$ losango preto para os dois setores,

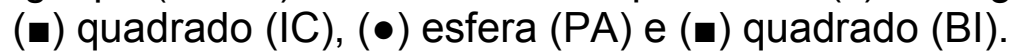
74

Figura 20. Classificação textural segundo Shepard (1954) para sedimentos dos campos de Spartina alterniflora em fevereiro de 2009. .76

Figura 21. Aspectos macro-visuais da área dos campos de Spartina alterniflora, (a) campo PA, (b) campo IC e (c) campo BI em maré baixa com aspectos do sedimento. Fotos: Braga \& Stein. .78

Figura 22. Classificação textural segundo Shepard (1954) para sedimentos dos campos de Spartina alterniflora em agosto de 2009. .79

Figura 23. Classificação textural segundo Shepard (1954) para sedimentos dos campos de Spartina alterniflora em março de 2010. 80

Figura 24. Aspectos macro-visuais dos bancos de Spartina alteniflora em Iguape (esquerda) e Cananéia (direita). Fotos: Braga \& Stein.

Figura 25: Distribuição de freqüência simples da estatura da Spartina alterniflora dos campos PA (I), IC (II), MP (III) e BI(IV), ao longo dos períodos, verão de 2009 (a), inverno de 2009 (b) e verão de 2010 (c). 90

Figura 26. Concentrações de $\mathrm{K}\left(\mathrm{mg} \mathrm{kg}^{-1}\right)$ da parte aérea e subterrânea da $S$. alterniflora nos campos Ponta do Arrozal (PA), Ilha Comprida (IC), Mar Pequeno 
(MP) e Barra do Icapara (BI) nos períodos de verão em inverno de 2009 e verão de 2010

Figura 27. Concentrações de $\mathrm{Ca}\left(\mathrm{mg} \mathrm{kg}^{-1}\right)$ da parte aérea e subterrânea da $S$. alterniflora nos campos Ponta do Arrozal (PA), llha Comprida (IC), Mar Pequeno (MP) e Barra do Icapara (BI) nos períodos de verão em inverno de 2009 e verão de 2010 101

Figura 28. Concentrações de $\mathrm{Fe}\left(\mathrm{mg} \mathrm{kg}^{-1}\right)$ da parte aérea e subterrânea da $S$. alterniflora nos campos Ponta do Arrozal (PA), Ilha Comprida (IC), Mar Pequeno (MP) e Barra do Icapara (BI) nos períodos de verão em inverno de 2009 e verão de 2010. 103

Figura 29. Concentrações de $\mathrm{Zn}\left(\mathrm{mg} \mathrm{kg}^{-1}\right)$ da parte aérea e subterrânea da $S$. alterniflora nos campos Ponta do Arrozal (PA), Ilha Comprida (IC), Mar Pequeno (MP) e Barra do Icapara (BI) nos períodos de verão e inverno de 2009 e verão de 2010.

105

Figura 30. Concentrações de $\mathrm{Cr}\left(\mu \mathrm{g} \mathrm{kg}{ }^{-1}\right)$ da parte aérea e subterrânea da $S$. alterniflora nos campos Ponta do Arrozal (PA), Ilha Comprida (IC), Mar Pequeno (MP) e Barra do Icapara (BI) nos períodos de verão e inverno de 2009 e verão de 2010. 107

Figura 31. Concentrações de $\mathrm{Pb}\left(\mathrm{mg} \mathrm{kg}^{-1}\right)$ da parte aérea e subterrânea da $S$. alterniflora nos campos Ponta do Arrozal (PA), llha Comprida (IC), Mar Pequeno (MP) e Barra do Icapara (BI) nos períodos de verão e inverno de 2009 e verão de 2010. 110

Figura 32. Concentrações de $\mathrm{Cd}\left(\mathrm{mg} \mathrm{kg}^{-1}\right)$ da parte aérea e subterrânea da $S$. alterniflora nos campos Ponta do Arrozal (PA), Ilha Comprida (IC), Mar Pequeno (MP) e Barra do Icapara (BI) nos períodos de verão e inverno de 2009 e verão de 2010. 112

Figura 33. Concentrações de $\mathrm{Hg}\left(\mathrm{mg} \mathrm{kg}^{-1}\right)$ da parte aérea e subterrânea da $S$. alterniflora nos campos Ponta do Arrozal (PA), Ilha Comprida (IC), Mar Pequeno (MP) e Barra do Icapara (BI) nos períodos de verão e inverno de 2009 e verão de 2010.

Figura 34: Varredura da absorbância da clorofila a em diversos comprimentos de onda, extraída pelos solventes DMSO e Acetona 90\% . 114

Figura 36: Concentração de clorofila obtidos eplos dois métodos de extração de clorofila a pelos solventes DMSO e acetona para um grupo de 8 amostras coletadas no verão de 2009 . 115

Figura 37: Concentrações de clorofila a, extraída com DMSO, no período de verão 2009, dos quadrantes PA e IC correspondentes ao setor sul (Cananéia), MP referente ao Mar Pequeno e BI (Iguape).

116

Figura 38: Concentração de clorofila a, extraída pelo solvente DMSO, no período do inverno de 2009, dos campos PA e IC correspondentes ao setor sul (Cananéia), MP (Mar Pequeno) e BI setor norte (lguape). 
Figura 39: Distribuição da clorofila a, extraída pelo solvente DMSO, no período do verão de 2010, dos campos PA e IC correspondentes ao setor sul (Cananéia), BI no setor norte (lguape).

Figura 40: Distribuição das concentrações de proteína solúvel total ( $\left.\mathrm{mg} \mathrm{g}^{-1} \mathrm{MF}\right)$ no período de inverno de 2009, dos campos PA e IC correspondentes ao setor sul (Cananéia), MP e BI no setor norte (lguape).

Figura 41: Distribuição das concentrações teores de proteína solúvel total $\left(\mathrm{mg} \mathrm{g}^{-1}\right.$ MF) em MF no período de verão de 2010, dos campos PA e IC correspondentes ao setor sul (Cananéia) e Bl ao norte (Iguape).

Figura 41. Gráfico de similaridade pelas distâncias euclidianas a partir destes dados hídricos normalizados em $\log (X+1)$ da água de superfície. Grupos à esquerda referentes a Cananéia $(C-x-y ; P A-x, I C-x)$ e grupos à direita referentes a Iguape (I-x-y; MP-x; BI-x). 


\section{RESUMO}

O Complexo Estuarino-Lagunar de Cananéia-Iguape (CELCl) é um importante sistema que apresenta diferenças na estrutura hídrica entre o setor sul, Cananéia e o setor norte, onde se encontra a cidade de Iguape que possui o canal artificial do Valo Grande pelo qual desvia grande afluxo de água doce do rio Ribeira de Iguape para o Mar Pequeno. Ao longo do Ribeira de Iguape se desenvolveu a agricultura com culturas de arroz, café e banana e a atividade mineradora, principalmente de ouro, zinco e chumbo. O desvio do canal gerou grande aporte de água doce no sistema, alterando as características físico-químicas e tróficas, escoando junto, resíduos das atividades produtoras. Nos estudos de impactos dessa região é comum a utilização de matrizes como sedimento e água para verificar a saúde do sistema estuarino, assim o objetivo do trabalho é estudar a Spartina alterniflora como espécie bioindicadora de contaminação por elementos traço e metais pesados no setor sul e norte do CELCI. A gramínea se desenvolveu fisiologicamente bem nos dois setores e apresentou diferenças na concentração dos elementos $\mathrm{K}, \mathrm{Ca}, \mathrm{Fe}, \mathrm{Zn}, \mathrm{Cr}, \mathrm{Pb}, \mathrm{Cd}$ e $\mathrm{Hg}$ entre as partes vegetais subterrânea (raiz e rizóides) e aérea (folha e caule) e entre os setores norte e sul. $\mathrm{O}$ macro-elemento $\mathrm{K}$ concentrou principalmente na parte aérea, o $\mathrm{Ca}$ e os elementos traço $\mathrm{Fe}$ e $\mathrm{Zn}$ se concentram na área radicular. Os metais pesados $\mathrm{Cr}$, $\mathrm{Pb}, \mathrm{Cd}$ e $\mathrm{Hg}$ super concentraram na região radicular da gramínea mostrando essa estrutura como importante e complexa área vegetal de estudo devido sua estrutura em forma de cabeleira e está em contato direto com o sedimento. Os metais pesados encontrados principalmente na área radicular tiveram concentrações maiores no setor norte do CELCI, na cidade de Iguape, que historicamente sofreu com a abertura do canal artificial e as atividades produtoras. A Spartina se mostrou como potencial espécie vegetal bioindicadora de contaminação por elementos traço por ser uma planta halófita, perene, fixa em contato direto com sedimento e a água do corpo hídrico estuarino refletindo assim, as alterações ambientais principalmente na área radicular da planta.

Palavras-chave: Spartina alterniflora, bioindicador, elementos traço, estuário, contaminação. 


\section{ABSTRACT}

The Cananéia-Iguape estuarine-lagoon complex (CELCI) is an important system that presents different water structures between north (Iguape) and south (Cananéia) sector. In the north sector is Iguape city wich has the Valo Grande artificial channel where diverts large influx of freshwater from the Ribeira de lguape river to Mar Pequeno. Along the Ribeira de Iguape culture of rice, coffee and banana and mining activity, particularly of gold, zinc and lead developed. The diversion channel has generated large amount of freshwater in the system, altering the physico-chemical and trophic characteristics, flowing together waste-producing activities. In studies of impacts in this region is common the use arrays as sediment and water to check the health of the estuarine system, so the aim of this work is to study the vegetal Spartina alterniflora a bioindicator of trace elements and heavy metals in the North and South sector of CELCl. The smooth cordgrass physiologically well is developed in these two sectors presented differences in the element concentrations of $\mathrm{K}, \mathrm{Ca}, \mathrm{Fe}, \mathrm{Zn}, \mathrm{Cr}, \mathrm{Pb}, \mathrm{Cd}$ and $\mathrm{Hg}$ between the plant parts, found in aboveground (leaves and stem) and belowground (roots) as well between the North and South sectors. The macro-element Ca were concentrated in the aboveground area, the $\mathrm{Ca}$ and the trace elements $\mathrm{Fe}$ and $\mathrm{Zn}$ were concentrated in the belowground parts. The heavy metals $\mathrm{Cr}, \mathrm{Pb}, \mathrm{Cd}$ and $\mathrm{Hg}$ were super concentrated in the belowground parts showing the structures as an important plant areas of study because roots structure are in form of hair and in direct contact with sediment. The heavy metals found mainly in the belowground area had higher concentrations in the northern sector, Iguape city, which historically has suffered with the opening of the artificial canal and productive activities. The smooth cordgrass showed to be a potential vegetable bioindicators of trace elements contamination because it is halophyte, perennial, fixed in contact direct with sediment and body water of the estuarine, thus reflecting the environmental changes especially in the plant roots area.

Key words: Spartina alterniflora, bioindicator, trace elements, estuary, contamination. 


\section{INTRODUÇÃO}

\section{Complexo estuarino-lagunar de Cananéia-Iguape}

As regiões costeiras recebem um fluxo contínuo de material de diversas origens sob as formas particulada e dissolvida, orgânica e inorgânica. Os materiais que transitam nos sistemas aquáticos sofrem processos físicos, químicos, biológicos e geológicos que os integram em seus ciclos biogeoquímicos. O balanço que ocorre nos ciclos biogeoquímicos locais refletem o grau de ação natural e antrópica que o sistema está submetido, fazendo com que alguns materiais sejam retidos nos sistemas estuarinos, outros sejam exportados, podendo ainda, ocorrer bioacumulação, como resposta às ações naturais e antrópicas. Esses impactos podem ocorrer tanto no sistema fluído do estuário, como podem ter influência nos domínios de interface como água-sedimento, águabiota, ar-água e mesmo aqueles de interface com a comunidade humana, promovendo mudanças sociais e econômicas nas imediações do sistema.

O complexo estuarino-lagunar de Cananéia/lguape, localizado no extremo sul de São Paulo (25오 - 47ํW), é uma região dotada de uma reserva natural protegida que apresenta diferenças em sua porção norte em relação ao sul, pois na primeira está localizado o Valo Grande, um canal artificial construído para facilitar o escoamento da produção agrícola do Vale do Ribeira comunicando o Rio Ribeira de Iguape com o Mar Pequeno. Este Canal inicialmente tinha cerca de $3 \mathrm{~m}$ de largura (1848), hoje atinge mais de $300 \mathrm{~m}$, tornando-se um local de alta erosão por onde passa um grande volume de água da bacia do Rio Ribeira que drena região de intensa atividade agrícola e com significante atividade industrial. O canal já passou por período de fechamento e em 1995 voltou a reabrir. Esse aporte de água é responsável pela alteração das características físicas da água do estuário como salinidade e turbidez, sobretudo na porção norte, e também, é responsável pela alteração da qualidade química da água como as concentrações de 
nutrientes, micronutrientes e traços. Transporta uma quantidade de material em suspensão que se deposita ao longo do sistema modificando as condições redox observadas no sedimento e alterando o fluxo de nutrientes e os processos da alça microbiana e vida bêntica, interferindo também na composição e metabolismo da fauna e flora locais, com efeitos na produtividade primária e nas características sócio-econômicas da população. Os reflexos dessas alterações já estão sendo observados no sul do sistema (Cananéia), como é possível notar quando se observa as variações na faixa de salinidade.

A região entre-marés da zona estuarina-lagunar de Cananéia-Iguape, é considerada um balneário e o município mais meridional do estado. Nesta região, observa-se o ecossistema marisma, o qual forma uma franja monoespecífica entre os ecossistemas manguezal e o estuário. Esta faixa é colonizada por Spartina alterniflora, uma planta herbácea (grama marinha) emergente, adaptada às condições saturadas do solo e presente em habitats lacustres, pântanos e zonas costeiras úmidas. Esta vegetação sustenta uma série de espécies de peixes, crustáceos e moluscos e biomassa de organismos macrobênticos devido a sua alta densidade, servindo também como local de procriação e desenvolvimento destes animais (Yamagata et al., 2007).

Os ecossistemas manguezal e marisma geralmente estão associados às margens de baías, enseadas, barras, desembocaduras de rios, lagunas e reentrâncias costeiras, onde ocorre o encontro das águas do rio e do mar, ou diretamente expostos à linha da costa. Esses sistemas são funcionalmente complexos, altamente resilientes e resistentes e, portanto, estáveis. A cobertura vegetal, ao contrário do que acontece nas praias arenosas e nas dunas, se instala em substratos de vasa com formação recente, de pequena declividade, sob a ação diária das marés de água salgada ou, pelo menos, salobra (SchaefferNovelli, 2005). 


\section{Spartina alterniflora}

Spartina alterniflora Loisel (1807) é uma gramínea que está muito bem adaptada às condições estuarinas, sendo capaz de tolerar tanto as variações climatológicas, como as flutuações de salinidade, bem como os longos períodos de exposição e inundação, formando densos bancos na região entre marés (Adaime,1978).

O gênero vegetal Spartina contém 16 espécies que ocorrem em wetlands das costas leste e oeste da América do Norte e do Sul, nas llhas Britânicas, Europa e na África. Esse gênero constitui um elemento importante das comunidades de wetlands, onde estabilizam os sedimentos, fornecem substrato para uma variedade de animais, sendo importante fonte de detritos (Walsh, 1990).

Uma combinação de características fisiológicas, estruturais e do ciclo de vida, permitem que Spartina spp se desenvolva de forma bem exuberante nos marismas médios, apesar de vários fatores adversos como: a alta concentração iônica, o baixo potencial hídrico, o baixo potencial redox, submersão periódica com suspensão das trocas gasosas com a atmosfera e a perturbação por correntes de maré podem comprometer o seu desenvolvimento (Davy \& Costa, 1992).

Outras adaptações, tais como a presença de uma epiderme foliar espessa, estômatos em criptas protegidas por papilas epidérmicas simples, feixes vasculares circundados por uma bainha de células lignificadas, e a utilização de um metabolismo $\mathrm{C} 4$, controlam efetivamente o balanço hídrico da planta e, consequentemente, previnem os efeitos osmóticos e tóxicos da acumulação excessiva de $\mathrm{NaCl}$. Além de ser excretado ativamente através de glândulas de sal, o $\mathrm{NaCl}$ é parcialmente excluído através da presença de 5 a 6 camadas de células suberinizadas entre a epiderme e o córtex das raízes (Bastos et al. 1993a). Amplos feixes aerenquimatosos interconectam as folhas, talos, rizomas e raízes, oxidam a rizosfera e previnem o acúmulo de $\mathrm{CO}_{2}$ e de toxinas resultantes da respiração anaeróbica das raízes e de microorganismos no sedimento alagado (Bastos et al. 1993a,b). 
A Spartina alterniflora (Figura 1) é uma macrófita fixa, halófita e perene pertencente à família Poaceae sendo uma espécie vegetal altamente produtiva, capaz de exportar num ano até $1300 \mathrm{~g} \mathrm{~m}^{-3}$ de detritos em um estuário. Pesquisas mostram que as espécies de macrófitas aquáticas que colonizam sistemas de wetlands (úmidos) e possuem grande capacidade de remover da coluna d'água elementos como o nitrogênio e o fósforo em excesso, os quais, em sobejo, caracterizam processos de eutrofização, pois estes vegetais fornecem estrutura para fixação de microorganismos que mediam as transformações desses "poluentes" além de realizar a incorporação e assimilação destes elementos em seus tecidos (Sezerino, 2002; 2006).

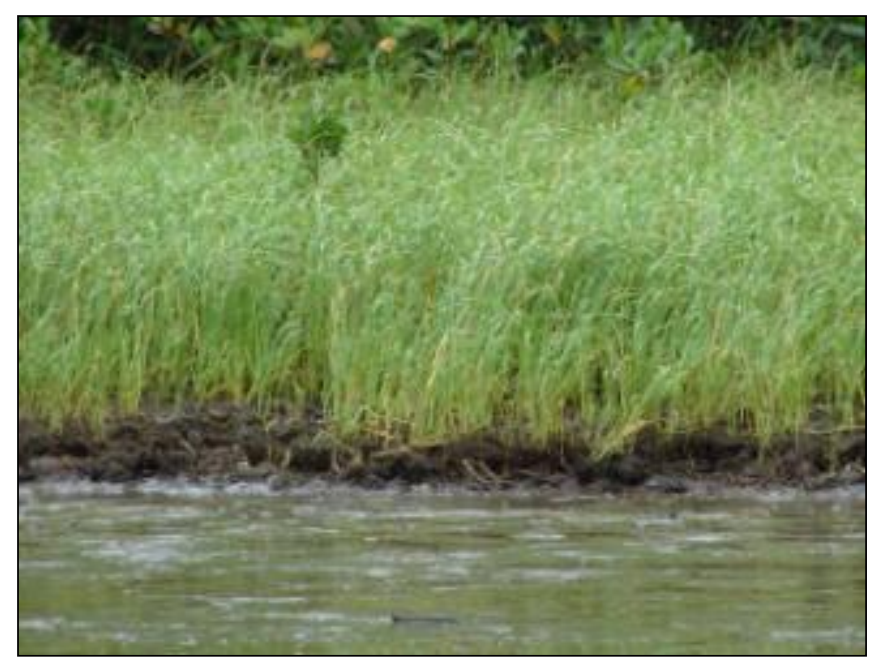

Figura 1. Aspecto de um campo de Spartina alterniflora, Família Poaceae, Ordem Cyperales em Cananéia (SP).

Pellenbarg (1985) mostrou que nos campos de Spartina alterniflora é gerado um acúmulo de matéria orgânica que pode reter metais traço $(\mathrm{Cu}, \mathrm{Zn}$ e $\mathrm{Fe})$ com diferenças de acumulação, segundo a estação sazonal.

Spartina alterniflora Loisel é, vernacularmente, chamada de capim-praturá. A espécie apresenta diversidade morfométrica, sendo conhecidas três formas: anã, média e alta. Foram registradas variações na produção em relação à altura das 3 formas consideradas. Há, contudo, opiniões divergentes quanto a essas 
diferenças, sendo estas atribuídas a fatores genéticos ou a fatores ambientais (Adaime, 1978).

\section{Spartina como bioindicadora de contaminação por elementos traço}

Os ecossistemas aquáticos são derradeiros sumidouros dos subprodutos gerados por diversas fontes naturais e antropogênicas e acolhem, de forma direta e indireta, uma grande variedade de poluentes que ameaçam a biodiversidade marinha. A introdução de poluentes em ambientes costeiros constitui um sério impacto à biota marinha e, em especial, a ambientes bentônicos, onde a maioria dos poluentes tende a se acumular (Nipper, 1990; Marques-Junior et al., 2002).

Nesses ambientes são encontradas as macrófitas como a Spartina alterniflora que, têm mostrado desempenhar importante papel na biogeoquímica de sistemas de marismas através de seu sistema ativo e passivo de circulação de elementos. Através de sua ação como bomba de nutrientes, a ativa absorção de elementos para os tecidos da planta pode promover a imobilização dos mesmos nos tecidos vegetais, como visto em wetlands construídas para tratamentos de esgoto e no uso das macrófitas na fitorremediação. Áreas úmidas (wetlands) são freqüentemente consideradas sumidouros para contaminantes, e há muitos casos em que macrófitas são utilizadas para remover poluentes, incluindo metais. Esta abordagem é geralmente conhecida como fito-estabilização, onde as plantas são usadas para imobilizar metais e armazená-los na área inferior, nas raízes e/ou solo, em contraste com a "fito-extração" em que, hiperacumuladores podem ser usados para remover metais do solo e concentrá-los nos tecidos da parte aérea (Weis \& Weis, 2004).

Podem ser considerados bioindicadores, os organismos capazes de indicar a qualidade ambiental dos ecossistemas em que eles se encontram. Esses organismos possuem capacidade de acumular contaminantes em seus tecidos e 
órgãos por meio do processo de bioconcentração, o que pode revelar o nível de contaminação do ambiente ao qual ele se relaciona.

Um organismo para ser utilizado como indicador de poluição deve apresentar as seguintes características:

- Ter capacidade de bioacumular o poluente em algumas ordens de grandeza antes de ser afetado por efeito agudo;

- Apresentar o mínimo de mobilidade, ou seja, ser sedentário para que possa ser representativo da área de coleta;

- Ser abundante na região escolhida para estudo;

- Ter longevidade suficiente para permitir a amostragem;

- Ter um tamanho razoável para atender ao protocolo analítico das análises dos contaminantes alvo da pesquisa;

- Ser fácil de amostrar e ser resistente o suficiente para sobreviver em laboratório, podendo assim ser submetido às análises de contaminantes;

- Ser tolerante a grandes variações de salinidades (eurihalinos);

- Apresentar fator de concentração elevado, que permita análise direta dos contaminantes sem necessidade de realizar pré-concentração;

- Apresentar uma relação simples entre o teor de contaminantes e sua concentração média na água do mar do ambiente;

Utilizar macrófitas em programas de biomonitoramento é comum em ambientes restritos como reservatórios, lagoas de estabilização e tratamento de água, como todo, sistemas lóticos e lênticos. Recomenda-se, para tal, o emprego das formas biológicas anfíbias, emergentes, submersas fixas e flutuantes fixas, desde que apresentem as características propostas por Brito (1983), tais como: serem sedentárias, acumuladoras de poluentes, longo ciclo de vida, abundantes e conhecidas taxonomicamente, resistentes à manipulação e transporte, de fácil manutenção e coleta.

O monitoramento feito por meio de macrófitas pode ser realizado pelo indicativo de sua presença ou ausência, como também pela análise de 
parâmetros, tais como: tamanho da população ou comunidade, forma e atributos funcionais (Murphy, 2000). Para este autor, grupos funcionais de macrófitas tendem a ocupar seções discretas de gradientes ambientais e, a identificação das espécies do grupo permite usar sua ocorrência no ambiente para predizer a existência de tipos pré-definidos daqueles gradientes. Além disso, os grupos funcionais são definidos em relação a certos atributos quantitativos, geralmente morfológicos, de fácil visualização e medição no campo.

Os organismos vegetais são excelentes indicadores de alterações ambientais e são importantes no acompanhamento dos processos de bioacumulação e biomagnificação, pois representam o primeiro elo da cadeia trófica.

Um dos principais problemas relativos à contaminação por metais traço, em ambientes aquáticos, é a alta meia-vida biológica destes elementos. Neste sentido, os metais traço merecem especial atenção, primeiro porque não são facilmente eliminados do ecossistema aquático por processos naturais, em contraste com os poluentes orgânicos e, em segundo, porque formam complexos estáveis com minerais e substâncias orgânicas (Mazon et al., 2000).

Os organismos que vivem próximos às regiões industriais, e mesmo em zonas pelágicas próximas, possuem concentrações de metais traços, distantes das concentrações basais (Braga, 2002). Dentre os diversos metais traço com importância ecológica aponta-se o estudo do chumbo e do cádmio, devido às suas toxicidades, mesmo quando em baixas concentrações, e do zinco, porque exerce um duplo papel na biota, participando como micronutriente ou contaminante, dependendo das concentrações (Braga, 2002).

A compreensão da química de metais traço no meio ambiente está relacionada com interações bioquímicas dos mesmos no meio aquático. Processos metabólicos nos organismos desempenham uma importante função na suscetibilidade para a toxicidade de metais traço. Alguns metais podem ser eliminados por algumas espécies e acumulados por outras. O acúmulo pode 
ocorrer através de complexos solúveis de baixo peso molecular em umas espécies e, através de produtos insolúveis em outras.

Genericamente, os metais traço podem apresentar toxicidade maior quando formam complexos ou ligantes com compostos orgânicos. A forma metilada do metal é altamente tóxica no ambiente aquático e no sistema biológico. As modificações produzidas por este agente tóxico podem causar perda da função de biomoléculas, resultando em mau funcionamento ou até morte de células afetadas. As biomoléculas comumente afetadas apresentam $\mathrm{O}, \mathrm{S}$ e $\mathrm{N}$ em sua composição e, quando os metais ligam-se a estes grupos, eles podem inativar importantes sistemas enzimáticos. Por outro lado, ligações metal-proteína (metalotioneínas e fitoquelatinas, seqüestradores de metais), com controle tipicamente elevado nos níveis de metais-traço, modificam a toxicologia e biodisponibilidade de metais acumulados, ocasionando subseqüente redução de toxicidade. Em baixas concentrações, eles não são tóxicos, porém algumas vezes são bioacumulados atingindo níveis de concentração que podem ser tóxicos para outros organismos através da cadeia alimentar (Garry, 1995).

Weis e Weis (2004) questionam se os ecossistemas marisma e manguezal são sumidouros ou fontes de poluentes. Muitos autores freqüentemente afirmam que esses ecossistemas funcionam como sumidouros de poluentes, reduzindo a contaminação dos ecossistemas adjacentes. Enquanto o sedimento, que tende a ser anóxido e redutor, agindo como sorvedouro, a vegetação de marisma pode tornar-se uma fonte de contaminação de metais através das atividades específicas das plantas. As plantas oxidam o sedimento deixando os metais mais biodisponíveis. Os metais podem ser absorvidos pelas raízes, transportados para os tecidos da parte aérea da planta, de onde são excretados. A camada de húmus com material em decomposição pode acumular mais metais que, são lixiviados ou apresentam-se disponíveis para os consumidores de detritos. Trabalhar o marisma como alternativa de tratamento de água é uma forma de retardar o processo de liberação de poluentes para a água. Como os níveis de poluentes aumentam, a habilidade do ecossistema incorporar 
resíduos pode ser prejudicada e esses sistemas úmidos podem se tornar fonte de poluentes.

Uma característica marcante das raízes de algumas macrófitas de marismas é a presença da rizoconcentração de metais ou plaquetas nas raízes (Vale et al., 1990). Estas estruturas são compostas principalmente por hidróxidos de ferro e outros metais como manganês que são mobilizados e precipitados na superfície radicular. Os metais são mobilizados do sedimento estuarino anóxido reduzido e concentrados em microambientes oxidados ao redor das raízes. Essas concentrações chegam a ser de 5 a 10 vezes a concentração encontrada no sedimento contíguo (Sundby et al.,1998).

Pela imediata oxidação do solo na vizinhança da rizosfera, as plantas alteram a distribuição de metais no sedimento de marisma. Doyle e Otte (1997) verificaram que as concentrações de diversos metais eram superiores em solos vegetados do que em solos não vegetados e, eram particularmente superiores em solos adjacentes às raízes da plantas.

Em um estudo da concentração de $\mathrm{Cd}$ e $\mathrm{Zn}$ em sedimentos de áreas cobertas por $S$. alterniflora comparados com sedimentos de planície de maré sem cobertura vegetal, foi mostrado que as concentrações de metais entre 5 e $15 \mathrm{~cm}$ de profundidade (correspondendo a máxima biomassa radicular) eram 4 vezes superiores sob a vegetação (Lacerda et al., 1997). As atividades do vegetal quanto à mobilização do metal pela oxidação da zona radicular e ao movimento para a rizosfera foram considerados responsáveis pelo acréscimo. Resultados similares foram encontrados em campos com S. marítima por Caçador et al. (1996) que concluíram que a influência das raízes na concentração de metais em sedimentos de marisma são resultantes da produção de complexos compostos orgânicos e a oxidação da rizosfera.

Quando as plantas de zonas úmidas translocam os metais a partir do tecido radicular ao tecido aéreo, esses são acumulados em folhas e caules. $O$ grau de transferência ascendente é dependente das espécies de plantas, do metal e, de um número de condições ambientais. Para Aster tripolium, por exemplo, o 
chumbo se acumula principalmente nas raízes em baixa salinidade, enquanto que em maior salinidade, há maior proporção de chumbo translocado para a parte aérea. Uma associação inversa de metais em plantas e sedimentos foi notada para esta espécie, como também para a Spartina spp. novamente sugerindo a absorção vegetal a partir do sedimento (Fitzgerald et al. 2003).

Caçador et al. (2000) notaram as variações sazonais nas concentrações de zinco, cobre, chumbo e cádmio nas raízes de Spartina maritima e Halimone portulacoides. Os níveis mais baixos nas raízes foram observados em janeiro e aumentaram durante o período de crescimento, sugerindo que as atividades da planta foram responsáveis pela absorção. Concentrações dos metais nestes sedimentos foram menores enquanto que os níveis nas raizes foram maiores, sugerindo absorção da planta a partir do sedimento. Concentrações em tecidos de plantas jovens foram menores do que em tecidos de vegetais mais velhos.

No entanto, Gleason et al. (1979) encontraram em S. alterniflora, brotos que acumularam manganês, cobre e zinco rapidamente na primavera e em seguida, os níveis diminuíram. O declínio foi atribuído ao efeito da diluição durante o crescimento.

A liberação de metais dos tecidos foliares para a superfície foliar é um método para lidar com metais de importância relativa, que varia com a fisiologia dos indivíduos de cada espécie vegetal. A liberação de metais pelas plantas pode aumentar a bioviabilidade de metais nos estuários, especialmente em áreas urbanas e industriais, onde até mesmo lançamentos de pequenos sítios contaminados podem ter efeitos tóxicos na cadeia alimentar estuarina (Burke et al., 2000).

Os metais são associados aos cristais de sal excretados da superfície foliar adaxial. Do mesmo modo, a Spartina mostrou atividade de excreção de metais em cristais de sal liberados através dos hidatóides (glândulas de sal). A relação da liberação de metal com a excreção de sal sugere que haverá grande liberação de metal em salinidade elevada, quando há maior excreção de sal (Weis \& Weis, 2004). 
Metais encontrados nos tecidos da parte aérea vegetal são susceptíveis de permanecer quando estes tecidos morrem e se transformam em detritos. Metais armazenados em porções da parte aérea das plantas que morrem, decaem e se transformam em detritos, podem tornar-se disponíveis para depósito de consumidores e, o consumo de detritos carregados de metal pode causar efeitos deletérios aos consumidores (Dorgelo et al., 1995). Metais também podem ser lixiviados via detritos e serem reinseridos em águas estuarinas. Geralmente concentrações de metais aumentam na biomassa morta das plantas e detritos. $O$ desenvolvimento da comunidade microbiana na camada de húmus tende a facilitar o incremento de metais através da atividade metabólica da microbiota (Weis \& Weis, 2004).

A produção de detritos decorrente do processo de decomposição sustenta um dos mais importantes caminhos de transferência de energia dentro dos estuários, isto é, a teia alimentar detritívora. A alta produtividade primária dos marismas é considerada como essencial para o ambiente costeiro (Pomeroy \& Wiegert, 1981), pela formação de áreas de refúgio para acasalamento, berçário, moradia e alimento para várias espécies de aves residentes e migratórias, incluindo ainda pequenos roedores, répteis, moluscos, peixes e crustáceos (Day et al., 1989).

Apesar de sua grande produção, apenas uma pequena parte das macrófitas emergentes são utilizadas ao consumo direto pelos organismos estuarinos de níveis tróficos superiores. Adaptações morfológicas e anatômicas especiais fazem com que estas plantas apresentem materiais estruturais como celulose e lignina que são digeridas apenas por microorganismos que possuem enzimas celulósicas e lignolíticas, desta forma, a maior parte desta produção primária não é consumida diretamente, mas sim, como detrito gerado pelo lento processo de decomposição microbiana (Day et al., 1989).

Conhecer a capacidade de retenção de metais em $S$. alterniflora representa uma ferramenta que pode ser aplicada no monitoramento ambiental em sistemas estuarinos. 


\section{OBJETIVOS}

\section{Objetivo geral}

Este trabalho visa estudar a Spartina alterniflora como potencial espécie vegetal bioindicadora de contaminação por metais traço em sistemas estuarinos considerando o estudo em campos localizados em dois setores sob diferentes graus de influência antrópica do Complexo Estuarino-Lagunar de CananéiaIguape.

\section{Objetivos específicos}

- Avaliar parâmetros biogeoquímicos do corpo hídrico e de sedimentos relacionados à Spartina alterniflora em dois setores do complexo estuarino de modo a conhecer seu estado de conservação considerando o grau de influência antrópica.

- Avaliar características bióticas dos exemplares dos diversos campos de $S$. alterniflora estudados observando as diferenças regionais (setores norte e sul).

- Relacionar os dados biométricos com os dados ambientais dos dois setores do sistema.

- Avaliar a distribuição do conteúdo em elementos traço nos diferentes campos amostrados, verificando as diferenças de acumulação entre a parte aérea (folha e caule) e radicular.

- Avaliar status metabólico com base nos dados de proteína solúvel total e clorofila nos diferentes campos estudados. 
- Avaliar o potencial da Spartina alterniflora como espécie bioindicadora em sistemas estuarinos com base nos estudos das respostas observadas nos dois setores;

- Diagnosticar, com base na interpretação dos dados obtidos, as possíveis diferenças ambientais observadas ao longo do complexo estuarino-lagunar de Cananéia-Iguape mostrada pelo acoplamento entre dados abióticos e bióticos expressos pela associação $S$. alternifloraambiente. 


\section{III ÁREA DE ESTUDO}

A área alvo deste estudo é o Complexo Estuarino-Lagunar de CananéiaIguape (CELCI), localizado no litoral sul do estado de São Paulo. A região está situada entre as latitudes de $24^{\circ} 40^{\prime} \mathrm{S}$ e $25^{\circ} 05^{\prime} \mathrm{S}$ e as longitudes de $47^{\circ} 25^{\prime} \mathrm{W}$ e $48^{\circ} 10^{\prime} \mathrm{W}$ e consiste no principal complexo estuarino-lagunar da costa paulista, que somada ao baixo vale do Rio Ribeira de Iguape, forma a maior planície costeira do estado de São Paulo, denominada Planície Costeira de Cananéia-Iguape, perfazendo uma área de cerca de $2500 \mathrm{~km}^{2}$, como mencionado em Suguio \& Tessler (1992).

Os campos de Spartina alterniflora amostrados no Complexo EstuarinoLagunar de Cananéia-Iguape localizam-se em dois setores, um ao Norte localizado na região de Iguape e outro ao Sul, na região de Cananéia, sendo que um ponto intermediário norte também foi realizado ficando a amostragem no Mar de Cananéia, Mar Pequeno e Barra do Icapara (Figura 2).

Este estudo foi realizado no âmbito do Projeto VAGRA, proc. CNPq 552437/2007-7 e também do Projeto do Instituto Nacional de Ciência e Tecnologia de Transferência de Materiais Continente-Oceanos - CNPq-INCT - TMCOcean CNPq n 573.601/2008-9. 


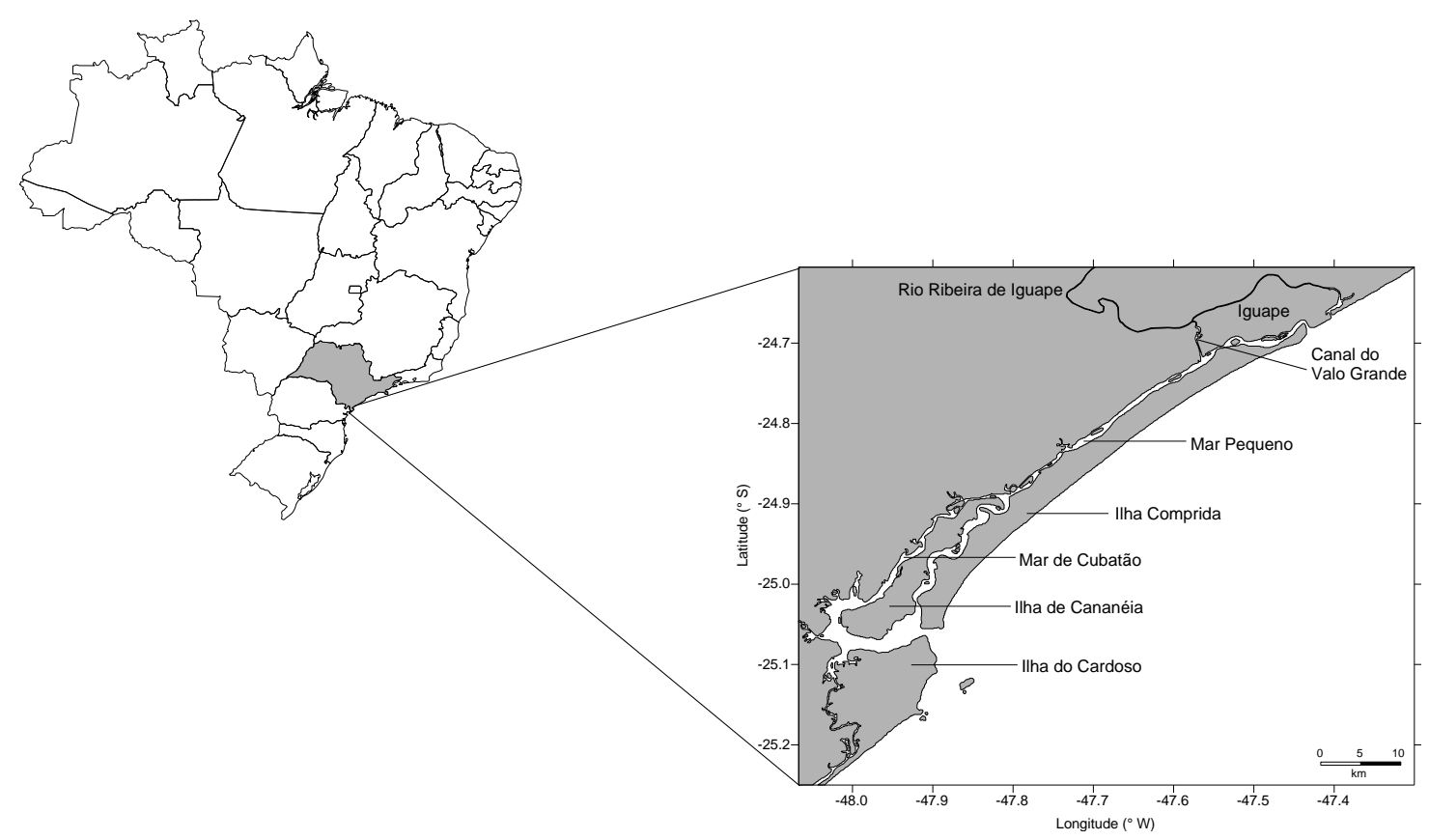

Figura 2. Localização do Complexo Estuarino-Lagunar de Cananéia-Iguape. Setor norte, barra de Icapara, Iha Comprida e a cidade de Iguape. Setor Sul, llha de Cananéia, Illha do Cardoso e llha Comprida.

Este sistema é composto de quatro principais ilhas (do Cardoso, de Cananéia, Comprida e Iguape), e por canais lagunares (Canal de Ararapira, Mar de Cubatão, Mar de Cananéia e Mar Pequeno, canal do Valo Grande e rio Ribeira de Iguape) que se comunicam com o oceano através de desembocaduras denominadas, de sul para norte, Barra do Ararapira, Barra de Cananéia, Barra de Icapara e Barra do Ribeira), sendo separado do oceano pela Ilha Comprida. As principais desembocaduras que circulam maior volume d'água são a Barra de Icapara e de Cananéia. Miyao et al.(1986) indicam que esses canais ocupam uma área de $115 \mathrm{~km}^{2}$ de superfície.

\section{O Canal artificial do Valo Grande}

O Valo Grande (Figura 3) é um canal artificial que liga diretamente o Rio Ribeira de Iguape com o Mar Pequeno. Foi construído entre 1827 e 1852 sobre as 
areias da Formação Cananéia e tinha, originalmente, $4 \mathrm{~m}$ de largura e $2 \mathrm{~m}$ de profundidade. Esse canal foi construído para facilitar o escoamento da produção agrícola do Vale do Ribeira comunicando o Rio Ribeira de Iguape ao Mar Pequeno. Com o passar dos anos, devido a pouca resistividade do material que compunha seu leito e margens, transformou-se no caminho preferencial do rio em direção ao oceano, apresentando erosão contínua de suas margens e ameaçando as construções de Iguape. Suas dimensões no fim do século XIX já superavam $100 \mathrm{~m}$ de largura e $10 \mathrm{~m}$ de profundidade (GEOBRÁS, 1966).

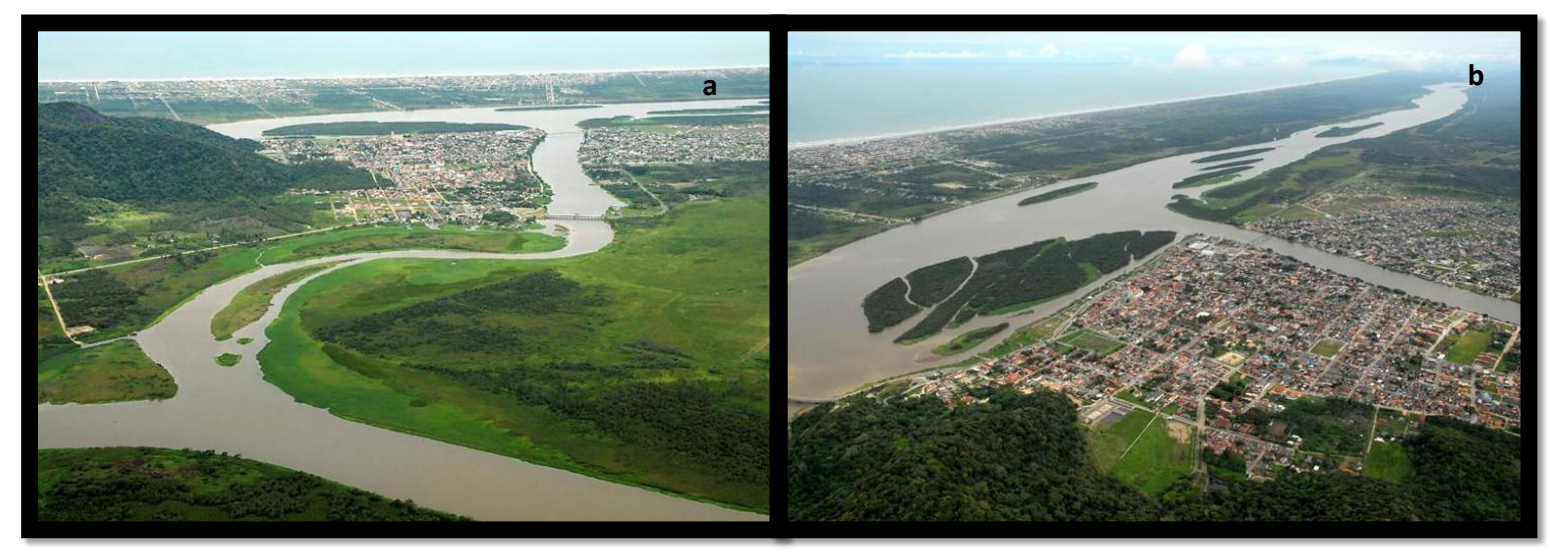

Figura 3. Canal artificial do Valo Grande, setor Sul, município de Iguape. Vista aérea da saída do rio Ribeira de Iguape ligando ao Mar Pequeno (a) e, divisão da Cidade e formação de ilhas no Mar Pequeno (b).

Em agosto de 1978, ocasião em que tinha cerca de 250m de largura e $7 \mathrm{~m}$ de profundidade, foi fechado pela construção de uma barragem situada à cerca de 2,5 km ao norte do Mar Pequeno. A obra visava evitar a continuidade do processo erosivo nas margens do canal, impedir a chegada anual de $9 \times 10^{9}$ de água e 2,6 milhões de toneladas de material sólido para o sistema $\left(1.000 .000 \mathrm{~m}^{3} / a n o\right.$ de sedimentos finos em suspensão e $1.000 \mathrm{~m}^{3} /$ ano de material arenoso oriundo das margens erodidas do próprio canal) (GEOBRÁS, 1966). Antes do fechamento, a salinidade mínima em todo sistema variava de 0 a 22 e os valores máximos de 14 a 32. Depois do fechamento estes valores passaram, respectivamente, para 16 a 30 e 26 a 34 (DAEE, 1989). 
O canal continuou fechado durante alguns anos, até ser rompido durante as enchentes de 1983, sendo posteriormente reconstruído. Em fevereiro de 1995, devido a uma outra grande enchente e ao forte assoreamento, a barragem do Valo Grande foi novamente reaberta, modificando mais uma vez as condições ecológico-ambientais do sistema estuarino-lagunar. Desde então o canal permanece aberto, permitindo que $60 \%$ da carga de material e água doce do Rio Ribeira de Iguape, desague no sistema (Mahiques et al., 2009).

\section{Principais impactos do Valo Grande}

A região de Cananéia é conhecida como uma região naturalmente eutrófica, onde a disponibilidade em nutrientes é influenciada fortemente pela variação sazonal e muito pouco pelas ações antrópicas. As chuvas na região estão relacionadas com as estações do ano, sendo os verões chuvosos e os invernos secos. As propriedades do sistema hídrico da região são altamente influenciadas pelo mangue (Braga, 1995).

A erosão e as enchentes foram responsáveis por um ciclo de abertura e fechamento que promoveu a variação das propriedades físicas e químicas da água com reflexos na biota e na atividade humana. Um exemplo disso foi apresentado pelo estudo de Braga e Chiozzini (2008) que avaliou as características físico-químicas do corpo hídrico do sistema estuarino sobre a influência do canal fechado (1992) e do canal aberto (2005), e, constataram grande influência do Valo Grande sobre o sistema com a alteração da salinidade e da ciclagem biogeoquímica dos nutrientes.

O Valo Grande tendo suas margens erodidas é responsável por grande aporte sedimentar no sistema, causando assoreamento. A maior parte da carga sedimentar, oriunda do rio, fica retida no Mar Pequeno havendo a variação da topografia de fundo, da margem do canal lagunar e o desenvolvimento de ilhas e feições sedimentares. As variações refletem a influência do aporte sedimentar, 
através do canal do Valo Grande, e a ação das correntes de maré (Freitas et al., 2008).

A região do Vale do Ribeira, como um todo, foi palco de intensa atividade de mineração e o refino de metais, até 1996, quando a empresa Plumbum Mineradora e as últimas minas de chumbo foram fechadas, deixando importante passivo ambiental. Essa região abrigou várias minas de chumbo, zinco e prata, que estiveram em atividade de 1945 a 1995. Vários estudos comprovaram que a bacia do Ribeira foi extremamente afetada pelas atividades de refino e mineração, pela contaminação de sedimentos fluviais por chumbo, zinco, cobre e arsênio e, mais esporadicamente, pelo registro de elevadas concentrações de metais na água.

Cunha (2003), estudando a região, concluiu que embora as atividades de mineração e metalurgia tenham cessado em 1996, as populações dessa região ainda convivem com várias fontes de contaminação ambiental, em especial, o chumbo e o arsênio, tipicamente originados da atividade de extração, beneficiamento e refino mineral. As emissões de metais para a atmosfera, durante décadas de funcionamento da refinaria, e a subseqüente deposição de particulados, foram responsáveis pela contaminação de solos e sedimentos nessa região. Porém, a porção Sul do sistema, que envolve a llha de Cananéia, corresponde à região sob menor influência antrópica. 


\section{MATERIAL E MÉTODOS}

Tendo em vista a caracterização do corpo hídrico nas imediações dos campos de S. alterniflora no complexo Estuarino-Lagunar de Cananéia-Iguape foram realizadas coletas de água superficial do corpo de água em dois pontos fixos localizados nos principais canais do estuário, um ao norte e outro ao sul do sistema, sendo coletadas amostras no período de 13h/dia acompanhando um ciclo de maré.

A caracterização das águas junto aos campos de Spartina alterniflora foi feita pela coleta de amostras nas bordas adjacentes ou no meio do campo, de acordo com a situação da maré no momento da coleta.

Foram realizadas 3 campanhas (verão e inverno 2009 e verão 2010) para coleta de material biológico e hidrogeoquímico, sendo avaliados dois setores, um ao norte (Iguape) e outro ao sul (Cananéia), do Complexo Estuarino-Lagunar de Cananéia-Iguape. A campanha de verão foi realizada no período de 09 a 16 de fevereiro de 2009, no período de inverno ocorreu entre 17 e 24 de agosto de 2009 e por fim, a coleta de verão 2010 ocorreu entre os dias 13 e 17 de março de 2010. A amostragem biológica do verão de 2009 foi tomada como parte da coleta piloto, quando foram testadas técnicas de amostragem e análises.

\section{Delineamento amostral}

$\mathrm{Na}$ campanha de verão de 2009 (coleta piloto) e inverno de 2009, foram realizadas amostragens em campos de $S$. alterniflora no setor sul. O primeiro campo foi amostrado na llha de Cananéia, denominado de Ponta do Arrozal (PA), e o segundo na llha Comprida (IC) (Figura 4). Nesses dois períodos, a amostragem do setor norte incluiu um campo de $S$. alterniflora e uma amostra do corpo de água, junto ao Mar Pequeno (MP) sem incluir um acompanhamento das 13h (Figura 5), e por fim, um campo foi amostrado em Iguape, mais precisamente 
próximo a Barra de Icapara (BI), na área da Ilha Comprida (Figura 6), com amostragem do corpo hídrico, águas superficiais por $13 \mathrm{~h}$.

$\mathrm{Na}$ amostragem do verão de 2010 houve coleta de material biológico e hidrogeoquímico nos dois campos do setor sul, Ilha Comprida (IC) e Ponta do Arrozal (PA). Para o setor norte, somente foi feita amostragem biológica no campo da Barra de Icapara (BI), havendo a amostragem hidrogeoquímica do seu entorno.

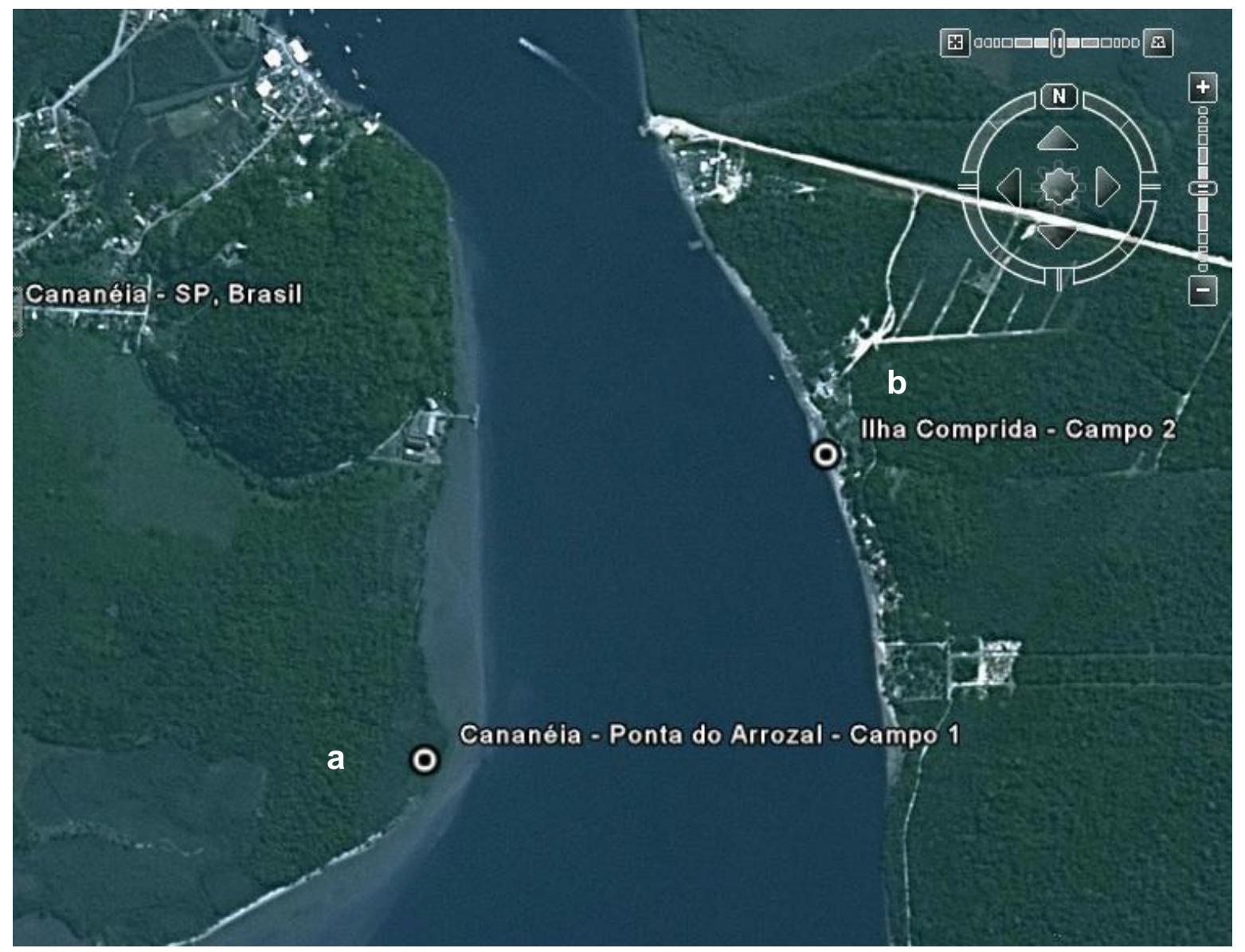

Figura 4. Área amostral do setor sul do complexo estuarino-lagunar de Cananéia-Iguape. Visualiza-se o Campo da Ponta do Arrozal (a) junto à llha de Cananéia e o Campo da ilha Comprida (b). Fonte: Google Earth. 




Figura 5. Ponto amostral do setor adjacente norte do Complexo Estuarino-Lagunar de Cananéia-Iguape, campo localizado no Mar Pequeno. Fonte: Google Earth.

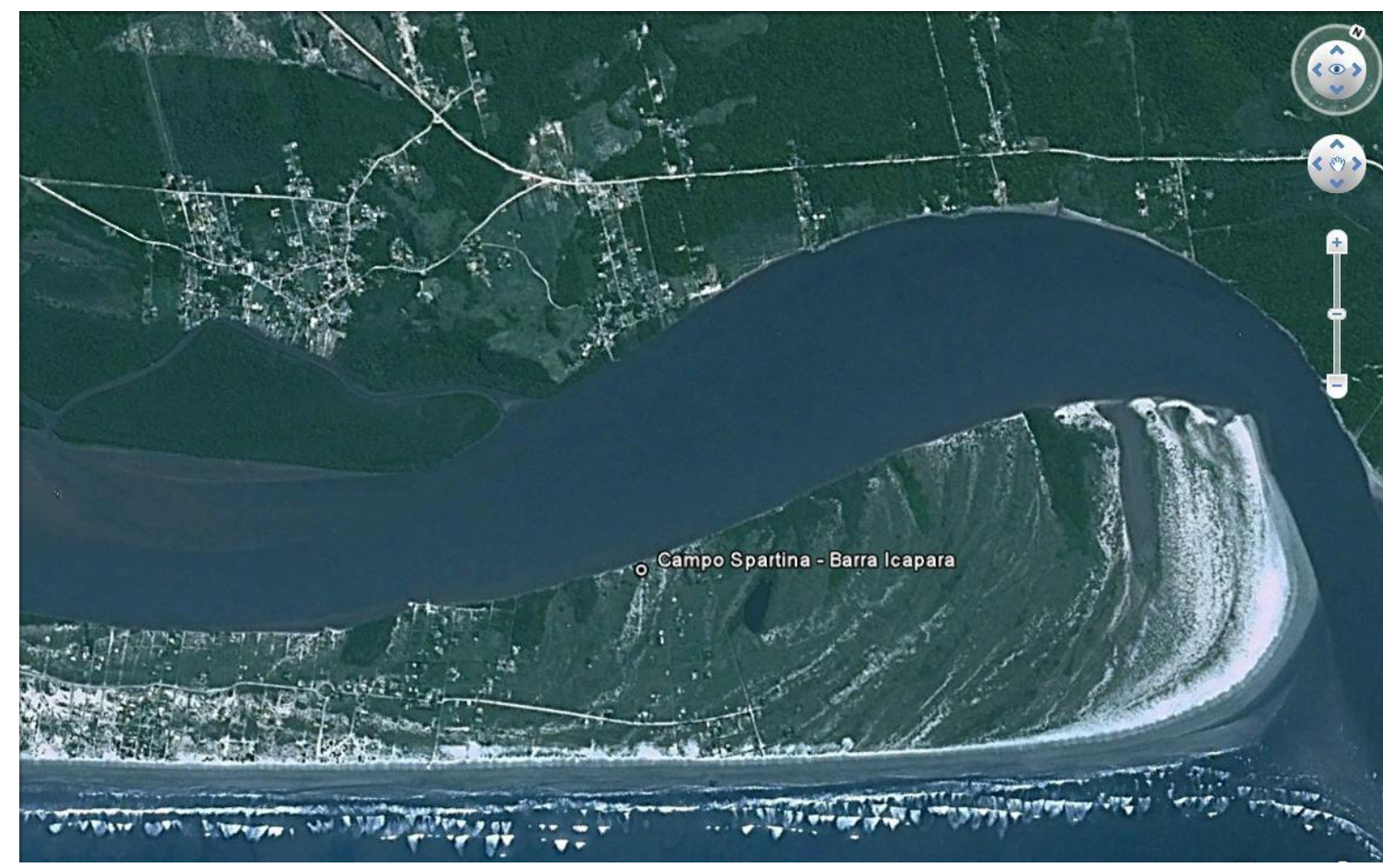

Figura 6. Ponto amostral ao setor norte do Complexo Estuarino-Lagunar CananéiaIguape, próximo à Barra do Icapara. Fonte: Google Earth. 
A distribuição amostral da campanha de verão 2009 encontra-se na Tabela 1.

Tabela 1: Denominação, distribuição e localização dos campos e quadrados amostradores da gramínea e das estações de coleta hidrogeoquímica, no período de Verão de 2009.

\begin{tabular}{|c|c|c|c|c|c|c|}
\hline Região & Local & Data & $\begin{array}{l}\text { Quadrados } \\
\text { amostrados }\end{array}$ & $\begin{array}{l}\text { Sigla do } \\
\text { quadrado }\end{array}$ & $\begin{array}{c}\text { Latitude } \\
\text { S }\end{array}$ & $\begin{array}{c}\text { Longitude } \\
\text { W }\end{array}$ \\
\hline \multirow{2}{*}{$\begin{array}{c}\text { Sul } \\
\text { (Cananéia) }\end{array}$} & $\begin{array}{c}\text { Ponta do } \\
\text { Arrozal } \\
\text { Cananéia } \\
\text { (PA) }\end{array}$ & \multirow[t]{2}{*}{$11 / 02 / 09$} & 1 & QA-1 & $25^{\circ} 01^{\prime} 64$ & $47^{\circ} 53^{\prime} 57$ \\
\hline & $\begin{array}{c}\text { Ilha } \\
\text { Comprida } \\
\text { (IC) }\end{array}$ & & 1 & QC-1 & $25^{\circ} 01^{\prime} 37$ & $47^{\circ} 55^{\prime} 00$ \\
\hline \multirow[b]{2}{*}{$\begin{array}{c}\text { Norte } \\
\text { (Iguape) }\end{array}$} & $\begin{array}{c}\text { Mar Pequeno } \\
(\mathrm{MP})\end{array}$ & $12 / 02 / 09$ & 1 & QP-1 & $24^{\circ} 50^{\prime} 90$ & $47^{\circ} 44^{\prime} 70$ \\
\hline & $\begin{array}{l}\text { Barra do } \\
\text { Icapara - Ilha } \\
\text { Comprida } \\
\text { (BI) }\end{array}$ & $13 / 02 / 09$ & 1 & QI-1 & $24^{\circ} 41^{\prime} 17$ & $47^{\circ} 26^{\prime} 64$ \\
\hline \multirow{2}{*}{$\begin{array}{c}\text { Amostragem } \\
\text { hidrogeoquímica }\end{array}$} & \multicolumn{2}{|c|}{$\begin{array}{c}\text { Estação Cananéia } \\
(11 / 02 / 2009)\end{array}$} & \multicolumn{2}{|c|}{ Coletas: $08: 00$ às $20: 00$} & $25^{\circ} 01^{\prime} 90^{\prime}$ & $47^{\circ} 54^{\prime} 91$ \\
\hline & \multicolumn{2}{|c|}{$\begin{array}{c}\text { Estação Iguape } \\
(13 / 02 / 2009)\end{array}$} & \multicolumn{2}{|c|}{ Coletas: $07: 00$ às 19:00 } & $24^{\circ} 42^{\prime} 16$ & $47^{\circ} 32^{\prime} 18$ \\
\hline
\end{tabular}

No inverno, a amostragem foi ampliada, havendo mais quadrados amostradores coletados em cada campo. As localidades foram mantidas e os quadrados distribuídos de forma a coletar gramíneas do infralitoral e do supralitoral, perfazendo assim uma amostragem da zona entre-marés. Nesse período, obteve-se a distribuição de acordo com a Tabela 2. 
Tabela 2: Denominação, distribuição e localização dos campos e quadrados amostradores no período de Inverno, na região sul, Ponta do Arrozal e llha Comprida (Cananéia), no setor adjacente norte, o Mar Pequeno e a Barra de Icapara - Ilha Comprida.

\begin{tabular}{|c|c|c|c|c|c|c|}
\hline Região & Local & Data & $\begin{array}{l}\text { Quadrados } \\
\text { amostrados }\end{array}$ & $\begin{array}{l}\text { Sigla do } \\
\text { quadrado }\end{array}$ & $\begin{array}{l}\text { Latitude } \\
\text { S }\end{array}$ & $\begin{array}{c}\text { Longitude } \\
\text { W }\end{array}$ \\
\hline \multirow{8}{*}{ Sul (Cananéia) } & \multirow{4}{*}{$\begin{array}{c}\text { Ponta do } \\
\text { Arrozal } \\
\text { Cananéia } \\
\text { (PA) }\end{array}$} & \multirow{8}{*}{ 19/08/09 } & 1 & QA-1 & $25^{\circ} 01^{\prime} 47$ & $47^{\circ} 53^{\prime} 24$ \\
\hline & & & 2 & QA-2 & $25^{\circ} 01^{\prime} 50$ & $47^{\circ} 54^{\prime} 01$ \\
\hline & & & 3 & $\overline{Q A-3}$ & $25^{\circ} 01^{\prime} 90$ & $47^{\circ} 53^{\prime} 80$ \\
\hline & & & 4 & QA-4 & $25^{\circ} 01^{\prime} 94$ & $47^{\circ} 54^{\prime} 16$ \\
\hline & \multirow{4}{*}{$\begin{array}{c}\text { Ilha } \\
\text { Comprida } \\
\text { (IC) }\end{array}$} & & 1 & QC-1 & $25^{\circ} 01^{\prime} 37^{\prime}$ & $47^{\circ} 55^{\prime} 00$ \\
\hline & & & 2 & QC-2 & $25^{\circ} 01^{\prime} 37$ & $47^{\circ} 54^{\prime} 60$ \\
\hline & & & 3 & QC-3 & $25^{\circ} 01^{\prime} 42$ & $47^{\circ} 54^{\prime} 97$ \\
\hline & & & 4 & QC-4 & $25^{\circ} 01^{\prime} 42$ & $47^{\circ} 54^{\prime} 99$ \\
\hline \multirow{4}{*}{ Norte (Iguape) } & \multirow{2}{*}{$\begin{array}{c}\text { Mar } \\
\text { Pequeno } \\
\text { (MP) }\end{array}$} & \multirow{2}{*}{ 21/08/09 } & 1 & QP-1 & $24^{\circ} 50^{\prime} 94$ & $47^{\circ} 44^{\prime} 69$ \\
\hline & & & 2 & QP-2 & $24^{\circ} 50^{\prime} 96$ & $47^{\circ} 44^{\prime} 68$ \\
\hline & \multirow{2}{*}{$\begin{array}{c}\text { Barra do } \\
\text { Icapara- } \\
\text { Ilha } \\
\text { Comprida } \\
\text { (BI) }\end{array}$} & \multirow{2}{*}{$22 / 08 / 09$} & 1 & QI-1 & $24^{\circ} 41^{\prime} 17$ & $47^{\circ} 26^{\prime} 67$ \\
\hline & & & 2 & QI-2 & $24^{\circ} 41^{\prime} 70$ & $47^{\circ} 27^{\prime} 31$ \\
\hline \multirow{2}{*}{$\begin{array}{c}\text { Amostragem } \\
\text { hidrogeoquímica }\end{array}$} & \multicolumn{2}{|c|}{$\begin{array}{c}\text { Ponto Cananéia } \\
(19 / 08 / 2009)\end{array}$} & \multicolumn{2}{|c|}{ Coletas: $08: 00$ às $20: 00$} & $25^{\circ} 03^{\prime} 15$ & $47^{\circ} 91^{\prime} 51$ \\
\hline & \multicolumn{2}{|c|}{$\begin{array}{l}\text { Ponto Iguape } \\
(22 / 08 / 2009)\end{array}$} & \multicolumn{2}{|c|}{ Coletas: $07: 00$ às $19: 00$} & $24^{\circ} 70^{\prime} 24$ & $47^{\circ} 53^{\prime} 67$ \\
\hline
\end{tabular}

A amostragem do verão de 2010 foi mantida com o mesmo delineamento amostral do inverno de 2009, exceto o setor adjacente norte, no Mar Pequeno, que não houve coleta devido o campo da gramínea ter erodido, havendo assim a 
exclusão desse campo nos estudos nesse período, cuja distribuição amostral encontra-se na Tabela 3.

Tabela 3. Denominação, distribuição e localização dos campos e quadrados amostradores no Verão de 2010, na região sul, Ponta do Arrozal e Ilha Comprida (Cananéia) e o setor norte, Barra do Icapara - Ilha Comprida.

\begin{tabular}{|c|c|c|c|c|c|c|}
\hline Região & Local & Data & $\begin{array}{l}\text { Quadrados } \\
\text { amostrados }\end{array}$ & $\begin{array}{l}\text { Sigla do } \\
\text { quadrado }\end{array}$ & $\begin{array}{l}\text { Latitude } \\
\text { S }\end{array}$ & $\begin{array}{l}\text { Longitude } \\
\text { W }\end{array}$ \\
\hline \multirow{8}{*}{ Sul (Cananéia) } & \multirow{4}{*}{$\begin{array}{c}\text { Ponta do } \\
\text { Arrozal } \\
\text { Cananéia } \\
\text { (PA) }\end{array}$} & \multirow{4}{*}{$17 / 03 / 2010$} & 1 & QA-1 & $25^{\circ} 01^{\prime} 47$ & $47^{\circ} 53^{\prime} 24$ \\
\hline & & & 2 & QA-2 & $25^{\circ} 01^{\prime} 50$ & $47^{\circ} 54^{\prime} 01$ \\
\hline & & & 3 & QA-3 & $25^{\circ} 01^{\prime} 90$ & $47^{\circ} 53^{\prime} 80$ \\
\hline & & & 4 & QA-4 & $25^{\circ} 01^{\prime} 94$ & $47^{\circ} 54^{\prime} 16$ \\
\hline & \multirow{4}{*}{$\begin{array}{c}\text { Ilha } \\
\text { Comprida } \\
\text { (IC) }\end{array}$} & \multirow{4}{*}{$17 / 03 / 2010$} & 1 & QC-1 & $25^{\circ} 01^{\prime} 37^{\prime}$ & $47^{\circ} 55^{\prime} 00$ \\
\hline & & & 2 & QC-2 & $25^{\circ} 01^{\prime} 37$ & $47^{\circ} 54^{\prime} 60$ \\
\hline & & & 3 & QC-3 & $25^{\circ} 01^{\prime} 42$ & $47^{\circ} 54^{\prime} 97$ \\
\hline & & & 4 & QC-4 & $25^{\circ} 01^{\prime} 42$ & $47^{\circ} 54^{\prime} 99$ \\
\hline \multirow{3}{*}{ Norte (Iguape) } & \multirow{3}{*}{$\begin{array}{c}\text { Barra do } \\
\text { Icapara- } \\
\text { Ilha } \\
\text { Comprida } \\
\text { (BI) }\end{array}$} & \multirow{3}{*}{$15 / 03 / 2010$} & 1 & QI-1 & $24^{\circ} 41^{\prime} 17$ & $47^{\circ} 26^{\prime} 67$ \\
\hline & & & 2 & QI-2 & $24^{\circ} 41^{\prime} 70$ & $47^{\circ} 27^{\prime} 31$ \\
\hline & & & 3 & QI-3 & $24^{\circ} 41^{\prime} 92$ & $47^{\circ} 27^{\prime} 88$ \\
\hline \multirow{2}{*}{$\begin{array}{c}\text { Amostragem } \\
\text { hidrogeoquímica }\end{array}$} & \multicolumn{2}{|c|}{$\begin{array}{l}\text { Estação Fixa Cananéia } \\
(17 / 03 / 2010)\end{array}$} & \multicolumn{2}{|c|}{ Coletas: $07: 00$ às 19:00 } & $25^{\circ} 03^{\prime} 15$ & $47^{\circ} 91^{\prime} 51$ \\
\hline & \multicolumn{2}{|c|}{$\begin{array}{l}\text { Estação Fixa Iguape } \\
(15 / 03 / 2010)\end{array}$} & \multicolumn{2}{|c|}{ Coletas: $08: 00$ às $20: 00$} & $24^{\circ} 70^{\prime} 24$ & $47^{\circ} 53^{\prime} 67$ \\
\hline
\end{tabular}




\section{Parâmetros hidrológicos}

A amostragem da coluna da água foi feita com 0 uso de garrafa hidrográfica do tipo Nansen da marca Hydrobios ${ }^{\circledR}$ e garrafa van Dorn. As amostras para análise de oxigênio dissolvido e $\mathrm{pH}$ foram retiradas do primeiro coletor, enquanto as amostras para análise de salinidade, nutrientes (fósforo dissolvido e silicato dissolvido), clorofila-a e material particulado em suspensão foram retiradas do segundo amostrador. $\mathrm{Na}$ amostragem da água adjacente que banham os campos da gramínea, utilizou-se a frascaria adequada para cada parâmetro, coletando-se diretamente a água da superfície nos frascos, dentro da embarcação, tomando cuidado para evitar contaminação das amostras.

\subsection{Maré}

Foram utilizadas informações das tábuas de maré fornecida no endereço www.mares.io.usp.br/tabua, para elaborar as curvas de maré nos dias de coleta em todos os 3 períodos de campanhas, tendo como referência hidrográfica, 0 marégrafo da Base de Pesquisa do Instituto Oceanográfico da USP "Dr. João de Paiva Carvalho", situada na cidade de Cananéia.

\subsection{Temperatura}

A temperatura da água foi obtida utilizando termômetros de reversão protegidos e com precisão de $\pm 0,02{ }^{\circ} \mathrm{C}$. O tempo de estabilização dos termômetros foi de 10 minutos. A temperatura base para o trabalho foi tirada da média na água de superfície observada no momento da coleta no campo de $S$. alterniflora.

\subsection{Salinidade}

As amostras de água para determinação da salinidade foram coletadas nas águas de superfície próximas e junto ao campo de $S$. alterniflora utilizando-se frascos em vidro âmbar de $250 \mathrm{~mL}$. O frasco foi completamente cheio e 
hermeticamente fechado. As amostras foram preservadas ao abrigo da luz e as leituras realizadas em laboratório. A salinidade foi determinada pelo método indutivo com o auxílio de um salinômetro indutivo da marca Beckman $\AA$, RS10 devidamente calibrado com água normal padrão da Ocean Scientific International Ltd., com precisão de $\pm 0,005$.

\subsection{Oxigênio Dissolvido - OD}

A coleta de água para determinação do OD foi feita diretamente no meio do campo de $S$. alterniflora e também na coluna d'água no ponto próximo ao campo da gramínea utilizando-se frascos tipo erlenmeyer, com tampas mergulhadoras e volume calibrado, garantindo também que não houvesse formação de bolhas na coleta com o uso do redutor de bolhas (desmamador). A fixação efetivou-se com adição de $1 \mathrm{~mL}$ de cloreto de manganês II e $1 \mathrm{~mL}$ de iodeto de potássio alcalino. Após a coleta, os frascos foram armazenados ao abrigo da luz e posteriormente foi feita análise antes de completar 8 horas após coleta. A metodologia seguida foi a proposta por Winkler (1888), como descrito em Grasshoff et al. (1983), utilizando um titulador Metrohm automático em um Kit hydrobios/Kiel. O método apresenta precisão de $\pm 0,02 \mathrm{~cm}^{3} \mathrm{dm}^{-3}$ para teores de 2 $\mathrm{cm}^{3} \mathrm{dm}^{-3} \mathrm{e} \pm 0,04 \mathrm{~cm}^{3} \mathrm{dm}^{-3}$ para teores superiores.

\subsection{Potencial Hidrogeniônico - pH}

As alíquotas para análise de $\mathrm{pH}$ foram coletadas após as amostras de oxigênio dissolvido, também utilizando-se um dispositivo redutor de turbulência. A água para a determinação do $\mathrm{pH}$ foi coletada em frasco de vidro com boca larga e com tampa esmerilhada evitando-se a formação de microbolhas, como no oxigênio. Após fechamento do frasco, as amostras foram acondicionadas ao abrigo da luz. $\mathrm{O}$ pH foi medido com auxílio do medidor de $\mathrm{pH}$ Orion® P210A, com precisão de $\pm 0,001$, seguindo as recomendações de Aminot \& Chausspied (1983). 


\subsection{Nutrientes Dissolvidos}

As amostras de água foram transferidas da garrafa de van Dorn para frascos de polietileno de 1 litro, posteriormente armazenados em caixa térmica, com gelo até serem levados ao laboratório e processados.

Em laboratório, alíquotas para determinação de nutrientes (fosfato e silicato) foram filtradas em filtro de fibra de vidro GF/F Whatman pré-pesados. Filtrou-se volumes adequados de cada amostra com um kit de filtração Millipore, sob pressão constante de no máximo $200 \mathrm{mmHg}$. O filtrado foi dividido em dois frascos de polietileno de $250 \mathrm{~mL}$ numerados, que foram armazenados em freezer $\left(-20^{\circ} \mathrm{C}\right)$ para posterior análise de nutrientes dissolvidos (fosfato e silicato).

\section{a) Fósforo inorgânico Dissolvido}

A determinação do fosfato na água do mar baseia-se na reação desses íons com um reagente contendo molibdato, em meio ácido, produzindo um complexo: o fosfomolibdato. Neste método, ocorre uma reação quantitativa do fosfato com os íons molibdato, catalisada pelo antimônio, formando um complexo amarelado que é reduzido a um composto azul, por ação do ácido ascórbico, seguindo-se as recomendações de Grasshoff et al. (1983). A leitura foi feita a 880 $\mathrm{nm}$, em cubeta de cinco $5 \mathrm{~cm}$ de caminho óptico, pelo espectrofotômetro digital Spectronic modelo Genesys 2. Esse método oferece precisão de 0,02 $\mu \mathrm{M} \mathrm{P}-\mathrm{PO}_{4}{ }^{-3}$.

\section{b) Silicato Dissolvido}

O método aplicado para análise de silicato foi descrito por Grasshoff et al. (1983) e baseia-se no princípio da formação de um complexo colorido, o ácido silicomolibdico após o tratamento da amostra com molibdato. O método utiliza como redutor o ácido ascórbico. O ácido oxálico é também utilizado para reduzir a influência do fosfato na reação. Foi utilizada cubeta de $1 \mathrm{~cm}$ de caminho óptico e a leitura da absorbância foi feita à $810 \mathrm{~nm}$, em espectrofotômetro digital Spectronic modelo Genesys 2. Esse método oferece precisão de 0,02 $\mu \mathrm{M} \mathrm{Si-} \mathrm{Si}(\mathrm{OH})_{4}$. 


\subsection{Material em suspensão (MES) e material orgânico em suspensão (MOS)}

Cerca de um litro de água foi filtrada e o filtro foi retirado, dobrado e colocado em saco plástico com identificação, em seguida foi armazenado em freezer $\left(-20^{\circ} \mathrm{C}\right)$, para posterior análise de MES e MOS.

O MES foi determinado pela técnica gravimétrica descrita por Strickland \& Parsons (1968). Foi filtrado um volume conhecido de amostra de água em filtros de fibra de vidro Whatman GF/F (47 mm) previamente tratados e calcinados em mufla à $450 \stackrel{\circ}{\circ}$, por quatro horas. Estes filtros foram resfriados em dessecador $\mathrm{e}$ pesados em balança analítica BEL Engineering ${ }^{\circledR}$,modelo MARK $210 \mathrm{~A}$ com precisão $\pm 0,0001$, e devidamente identificados. Após a filtração foram acondicionados em embalagem plástica as quais permaneceram em dessecador com sílica gel e foram mantidos congelados até a análise. $O$ método consiste na secagem em estufa a uma temperatura de $60{ }^{\circ} \mathrm{C}$ até a obtenção de peso constante. A determinação do material em suspensão foi feita pela diferença de peso entre os filtros antes e depois da filtração. O material orgânico em suspensão (MOS) foi medido após calcinação dos filtros em mufla a $450{ }^{\circ} \mathrm{C}$ por $4 \mathrm{~h}$, como descrito por Strickland \& Parsons (1968).

\subsection{Pigmentos fotossintetizantes na água}

Alíquotas para determinação de pigmentos foram filtradas em filtro de fibra de vidro GF/F Whatmann, utilizando-se um kit de filtração Millipore, sob pressão constante de no máximo $200 \mathrm{mmHg}$. Os filtros foram congelados $\left(-20^{\circ} \mathrm{C}\right)$ até 0 momento da extração.

Para a determinação da concentração de pigmentos fotossintetizantes clorofila-a e feofitina foram filtrados volumes conhecidos de aproximadamente 350 $\mathrm{ml}$ da amostra em filtros Sartorius $\mathrm{GF} / \mathrm{F}(\varphi=47 \mathrm{~mm})$. Os filtros foram 
acondicionados em tubos de vidro, armazenados em dessecador e congelados em freezer $\left(-20^{\circ} \mathrm{C}\right)$ até a análise. Os pigmentos foram extraídos dos filtros macerados em acetona $90 \%(\mathrm{v} / \mathrm{v})$, mantidos no escuro e sob refrigeração de $5 \% \mathrm{C}$ por um período mínimo de $12 \mathrm{~h}$ horas. As amostras foram centrifugadas em $3500 \mathrm{rpm}$ por 10 minutos e o sobrenadante foi utilizado na leitura em espectrofotômetro. A equação utilizada para cl-a foi descrita em Jeffrey \& Humphrey (1975) e para feopigmentos foi utilizado o Lorenzen (1967).

\section{Parâmetros sedimentológicos}

As amostras de sedimento dos campos de Spartina alterniflora foram coletadas com auxílio de pás coletoras diretamente no meio dos quadrados amostrados em cada campo. As amostras foram armazenadas em sacos plásticos identificados para as análises de granulometria, matéria orgânica e percentual de carbonatos.

\subsection{Análise Granulométrica}

A análise granulométrica foi feita de acordo com a metodologia descrita em Suguio (1973). As análises foram realizadas no Laboratório de Sedimentologia Marinha do IOUSP.

As amostras foram previamente tratadas com a "queima" da matéria orgânica e do carbonato de cálcio. Após pré-tratamento as amostras sofreram peneiramento úmido, peneiramento seco e pipetagem.

Após as amostras estarem preparadas, ou seja, livres de $\mathrm{MO}$ e $\mathrm{CaCO}_{3}$, a análise granulométrica foi realizada pelo método de peneiramento mecânico. $O$ intervalo entre as peneiras foi de $1 / 2 \varphi$ da escala de Wentworth (1922). Cada amostra foi peneirada por 20 minutos. O material retido em cada peneira foi pesado e os resultados foram apresentados segundo a interpretação 
granulométrica de Folk \& Ward (1957), que considera a classificação, selecionamento, achatamento e tendência com base nas curvas de freqüência simples e acumulada.

Os parâmetros considerados na análise estatística são tamanho médio do grão $\left(d_{50}\right)$, desvio padrão, assimetria, curtose. A apresentação dos parâmetros estatísticos foram obtidos através da utilização do programa SYSGRAN (Camargo, 2005), seguindo a análise estatística baseado em Folk \& Ward, (1957).

\subsection{Análise de matéria orgânica e teores de carbonatos no sedimento}

Para a determinação de matéria orgânica sedimentar, mediu-se a massa de $2 \mathrm{~g}$ de sedimento em uma balança analítica de precisão $\pm 0,001 \mathrm{~g}$. Após a medida, o material é submetido a uma queima por 4 horas a $450^{\circ} \mathrm{C}$. Após a ignição da amostra, transfere a mesma para uma estufa por 1 hora até atingir a massa constante para depois pesá-la novamente. Calcula-se o teor de matéria orgânica pela diferença entre a massa inicial e a massa final (Strickland e Parsons, 1968).

A análise de carbonatos biodetríticos foi feita no laboratório de Sedimentologia do IOUSP por meio do método de Ingram (1971). Pesou-se aproximadamente 5,0 gramas de sedimento em uma balança analítica. Submeteuse a ataque com ácido clorídrico $10 \%$ em massa durante 12 horas. Secou-se então o sedimento e pesou-se novamente. O cálculo do teor de carbonato biodetrítico foi calculado conforme a equação abaixo:

$$
\% \mathrm{CaCO} 3=\frac{(\mathrm{g}) \text { Sed. antes } \mathrm{HCl}-(\mathrm{g}) \text { Sed. após } \mathrm{HCl} \times 100}{(\mathrm{~g}) \text { Sed. antes HCl }}
$$




\section{Parâmetros biológicos - Spartina alterniflora}

\subsection{Caracterização dos Bancos de S. alterniflora}

A caracterização dos bancos de $S$. alterniflora foi realizada com o uso de quadrados/quadrantes amostradores ou delimitadores de amostra de $35 \times 35 \mathrm{~cm}$ feitos com tubos de PVC. A amostragem foi feita de forma aleatória sobre 0 campo, sendo coletados todos os indivíduos dentro dos limites do quadrado (Figura 7). Deve-se ressaltar que na campanha de verão de 2009 (piloto), foi utilizado um quadrado de $50 \times 50 \mathrm{~cm}$. A localização da aplicação dos quadrados foi registrada com auxílio de GPS portátil da marca Magellan, modelo 3000XL, fotografada, e em seguida os indivíduos foram coletados, armazenados e acondicionados até a lavagem, biometria e análises sequenciais.



Figura 7: Quadrado amostrador de $35 \times 35 \mathrm{~cm}$ no campo de Spartina alterniflora.

Para uma caracterização biológica dos bancos de $S$. alterniflora, medidas de comprimento (medida entre o início do caule ao extremo foliar) e espessura do caule (medida na base do caule) foram obtidas com auxilio de fita métrica e paquímetro, respectivamente (Figura 8). 
A quantificação de indivíduos de cada quadrado amostrador foi realizada, totalizando a densidade dos quadrados de cada região. Em seguida os exemplares coletados foram preservados íntegros em $-20^{\circ} \mathrm{C}$ para posterior análises em laboratório.

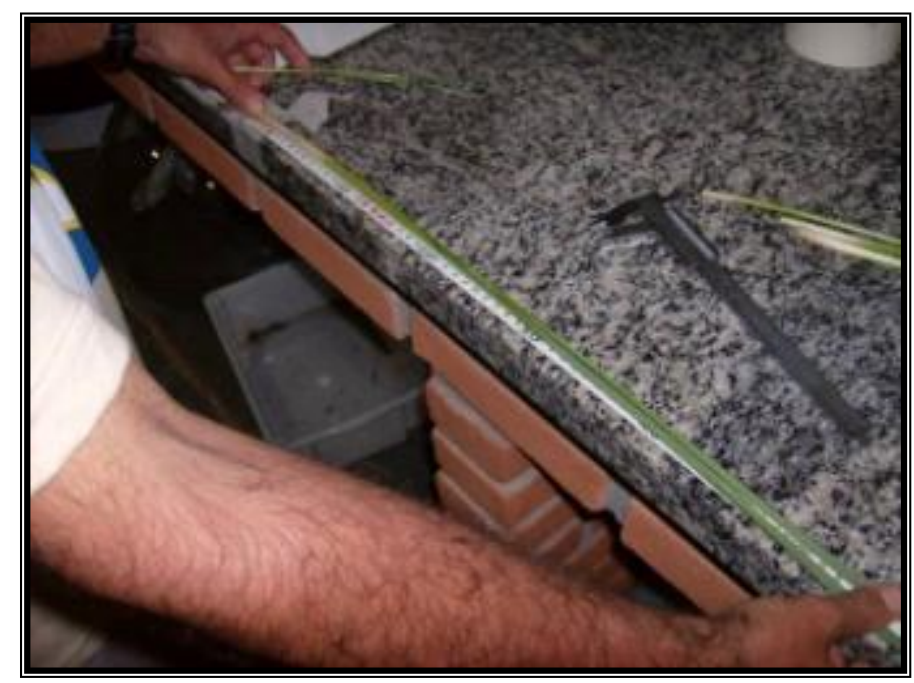

Figura 8: Medidas de comprimento e espessura da S. alterniflora.

\subsection{Determinação de clorofila-a em S. alterniflora}

Os espécimes de $S$. alterniflora, depois de coletados, limpos e secos, foram processados de forma a separar a parte viva da morta. Uma quantidade de material vegetal foi destinada para cada método de extração.

A clorofila a foi extraída da área foliar viva dos vegetais amostrados nos quadrantes de cada região, utilizando dois solventes, acetona $90 \%$ e o dimetilsulfóxido PA. Inicialmente realizou-se essa extração com os dois diferentes solventes (acetona e dimetil-sulfóxido) para verificar a eficácia e a facilidade de extração com cada um deles. O teste seguiu com análises dos mesmos indivíduos para cada solvente com biomassa aproximada de $100 \mathrm{mg}$ analisadas em triplicatas.

A extração feita com acetona passou pelas etapas: i) moagem com o auxílio de nitrogênio líquido para o rompimento das células, ii) pesagem de $100 \mathrm{mg}$ do macerado ainda resfriado, seguido de adição de $10 \mathrm{ml}$ de acetona $90 \%$, iii) 
agitação da solução e descanso por $24 \mathrm{~h}$ a $-20^{\circ} \mathrm{C}$. Após o período de descanso, as amostras foram centrifugadas por 10 minutos a $2600 \mathrm{rpm}$. A determinação do pigmento foi espectrofotométrica com leituras em diversos comprimentos de onda em cubeta de $10 \mathrm{~mm}$ de caminho óptico, seguindo o método de Arnon (1949).

Para a extração com dimetil-sulfóxido (DMSO), foi utilizado o método recomendado por Hiscox \& Israelstam (1979). Essa extração consistiu em pesar $100 \mathrm{mg}$ da área foliar viva e imersão em $7 \mathrm{~mL}$ de DMSO PA, posteriormente deixado em descanso ao abrigo da luz em temperatura ambiente $\left(25^{\circ} \mathrm{C}\right)$. Após $24 \mathrm{~h}$ acrescentou-se $3 \mathrm{~mL}$ do mesmo solvente e, a solução em seguida foi homogeneizada para posterior leitura de absorbância.

As leituras foram feitas em espectrofotômetro Milton Roy, Genesys 2, em diversos comprimentos de onda (Arnon, 1949).

\subsection{Proteína solúvel total na S. alterniflora}

A análise de proteína solúvel total foi realizada de acordo com o método de Bradford (1976), utilizando-se o reagente para ensaio protéico coomassie blue G-250 da Bio-Rad®.

Para a construção da curva de calibração, foi empregado Albumina Bovina Sérica (BSA) (1 mg mL ${ }^{-1}$ ) como proteína padrão para calibração. Utilizaram-se cinco alíquotas de albumina de soro bovino (20-100 $\mu \mathrm{L}, 1 \mathrm{mg} \mathrm{mL}^{-1}$, diluído $10 \mathrm{x}$ ) em triplicatas, $200 \mu \mathrm{L}$ de reagente de Bradford e água deionizada para completar 1,0 $\mathrm{mL}$. Após $5 \mathrm{~min}$ de ensaio, procedeu-se a leitura em espectrofotômetro (espectrofotômetro Milton Roy, Genesys 2) pela absorção a 595 nm, usando uma cubeta de polipropileno de percurso óptico de $1 \mathrm{~cm}$.

Para determinação da proteína solúvel total nas gramíneas, utilizou-se uma biomassa aproximada de $100 \mathrm{mg}$ da área foliar viva. As amostras foram feitas em triplicata e trituradas com o auxílio de nitrogênio líquido. A farinha da gramínea foi ressuspendida com tampão fosfato, centrifugada por $15 \mathrm{~min}$ a $4^{\circ} \mathrm{C}$ e $12000 \mathrm{rpm}$. 
Uma alíquota de $40 \mu \mathrm{L}$ do homogenato foi retirada e adicionado $760 \mu \mathrm{L}$ de água deionizada mais $200 \mu \mathrm{L}$ do corante, completando $1 \mathrm{~mL}$ de solução que foi lida a absorbância contra o branco. Os resultados foram padronizados de acordo com a massa fresca da gramínea e expressos em $\mathrm{mg} \mathrm{g}^{-1}$.

\subsection{Análise Multielementar em S. alterniflora}

A análise elementar foi realizada em parceria com 0 Laboratório de Análise por Ativação Neutrônica (LAN-CRPQ) - IPEN/CNEN (SP), com auxilio e supervisão da Prof ${ }^{a}$ Dra Mitiko Saiki.

A Análise por Ativação Neutrônica Instrumental (AANI) é uma técnica nuclear analítica que está entre os métodos mais importantes dentre os disponíveis para a análise de elementos traços. A sua principal vantagem é a capacidade de determinação de muitos elementos com alta sensibilidade sendo possível a sua determinação em níveis de $\mathrm{ng}^{-1}$ até \%, com exatidão e precisão. É uma técnica não destrutiva, a qual preenche dois requisitos básicos: a especificidade, que é a habilidade de correlacionar diretamente e de forma não ambígua o sinal obtido com o elemento procurado, e a seletividade, que vem a ser a possibilidade de medir o elemento em questão na presença de outros elementos que emitem sinais da mesma natureza. Devido a esses fatores, é uma técnica utilizada para a determinação de elementos químicos em amostras das mais variadas naturezas.

A sensibilidade disponível por AANI depende dos parâmetros de irradiação (fluxo de nêutrons, tempos de irradiação e decaimento), condições de medição (tempos de medição e eficiência do detector), parâmetros nucleares dos elementos em estudo (abundância isotópica, secção de choque para nêutrons, meias vidas e abundâncias de raios gama).

Nesta análise, a ativação da amostra a ser analisada através da irradiação com nêutrons é o primeiro passo. Cada núcleo atômico é capaz de capturar um nêutron durante a irradiação, iniciando-se assim uma reação nuclear. Após a 
captura forma-se um núcleo composto e o excesso de energia é liberado na forma de radiação gama ("prompt gamma rays") e/ou partículas. Este núcleo formado pode ser instável, e assim que formado começará a decair buscando uma configuração mais estável através da emissão de radiação pelos processos de decaimento $\alpha$, decaimento $\beta$-, decaimento $\beta+$, captura eletrônica. Na maioria dos casos, raios- $X$ e radiação gama ("delayed gamma rays") também são emitidos.

A reação nuclear mais utilizada em AANI é a reação de captura de nêutrons térmicos, ou a reação $(n, \gamma)$ :

${ }^{59} \mathrm{Co}+1 \mathrm{n} \rightarrow{ }^{60} \mathrm{Co}+$ radiação gama de captura ("prompt gamma rays")

O núcleo produto $\left({ }^{60} \mathrm{Co}\right)$ é radiativo e decai pela emissão de partículas beta e pela emissão de radiação gama, formando por fim um núcleo estável. Através da energia da radiação gama de decaimento e da respectiva meia-vida, o radioisótopo formado (núcleo produto) na reação nuclear pode ser identificado, permitindo assim realizar análises qualitativas e quantitativas do elemento contido na amostra.

A técnica de AAN apresenta duas categorias:

- Análise por ativação com nêutrons de raios gamas prontos ("prompt gamma rays"), também conhecida como PGNAA. A medição ocorre durante a irradiação.

- Análise por ativação com nêutrons de raios gama de decaimento ("delayed gamma rays").

Esta última é a mais comum, e o termo AAN é normalmente empregado para este tipo de análise e também será utilizado com este sentido no presente trabalho.

\section{- Procedimento experimental}

Para a determinação multielementar da Spartina alterniflora foram utilizadas duas partes diferentes da planta: a raiz e os rizóides, chamadas partes 
subterrâneas e o caule e folhas, as partes aéreas. Em cada uma das partes trabalhadas foram feitos "pools" de indivíduos vegetais de cada quadrado das regiões estudadas.

Após a coleta nos campos das duas regiões, o vegetal passou pelas seguintes etapas até serem preparadas para a injeção no reator:

Limpeza: todas as partes da gramínea foram inicialmente lavadas com água corrente para a retirada de lama, matéria orgânica morta e demais detritos, para em seguida sofrer outra lavagem, esta, com água destilada. Após as lavagens, a planta foi seca com papel toalha para retirar o excesso de água e não interferir na próxima etapa;

Moagem: nessa fase, a planta foi separada, com auxilio de uma tesoura de titânio, em duas partes, a subterrânea e a aérea. Separadamente, cada parte foi moída com nitrogênio liquido em almofariz de polipropileno, até virar um pó fino;

Secagem: o pó fino foi seco no liofilizador (Liobras - L101, pressão de vácuo $0,015 \mathrm{mmHg}$ ) por $48 \mathrm{~h}$.

O material seco e acondicionado em recipiente adequado foi levado para Laboratório de Análise por Ativação Neutrônica (LAN-CRPQ) - IPEN/CNEN, onde foi realizada a análise multielementar no Reator IEA - R1 do Instituto de Pesquisas Energéticas e Nucleares.

\section{- Preparação de padrões sintéticos de elementos.}

Os padrões para análise por ativação comparativa foram preparados pipetando alíquotas de soluções padrões simples ou multielementares sobre tiras de dimensões de $1,3 \mathrm{~cm} \times 3,0 \mathrm{~cm}$ de papel de filtro Whatman $\mathrm{N}^{0}$. 40. Estas soluções foram preparadas a partir das soluções certificadas adquiridas da Spex Certiprep, USA. Os elementos do padrão misto ou multielementar foram selecionados dependendo das meias vidas dos radioisótopos a serem medidos. Além disso, nesta escolha tomou-se o cuidado para que não ocorra o problema de interferência dos radioisótopos com a emissão de raios gama com energias 
próximas. Após a secagem das alíquotas a temperatura ambiente no interior de um dessecador, estas tiras de papel de filtro foram dobradas e colocadas dentro de invólucros de polietileno. Estes invólucros foram confeccionados usando folhas de polietileno previamente lavadas com solução de ácido nítrico p.a. diluído e água purificada MilliQ no sistema de purificação da Millipore.

\section{- Irradiação, medição da radiação gama e cálculos}

Para análise por ativação com nêutrons (NAA,) cerca de $180 \mathrm{mg}$ de cada uma das amostras pesados em invólucro de polietileno foram irradiados no reator IEA-R1 juntamente com os padrões sintéticos de elementos. As irradiações de 16 $\mathrm{h}$ sob fluxo de nêutrons térmicos de cerca de $5,0 \times 10^{12} \mathrm{n} \mathrm{cm}^{-2} \mathrm{~s}^{-1}$ foram realizadas para determinação $\mathrm{Br}, \mathrm{Ca}, \mathrm{Cd}, \mathrm{Cr}, \mathrm{Fe}, \mathrm{K}, \mathrm{La}, \mathrm{Mo}, \mathrm{Rb}, \mathrm{Sb}, \mathrm{Sc}$, e Zn

Após adequados tempos de decaimento, as amostras e os padrões sintéticos irradiados foram medidos usando um detector de Ge hiperpuro Modelo GX1820 acoplado a um analisador de espectro digital DAS 100, ambos da marca Canberra. A resolução do sistema utilizado foi $1,0 \mathrm{keV}$ para pico de $121,97 \mathrm{keV}$ do ${ }^{57} \mathrm{Co}$ e de $1,78 \mathrm{keV}$ para o pico $1332,49 \mathrm{keV}$ do ${ }^{60} \mathrm{Co}$. Para aquisição e processamento do espectro foi utilizado o Programa Gennie 3.1 da Canberra. As amostras e padrões foram medidos pelo menos em dois diferentes tempos de decaimento para detecção de um número maior de elementos e também para evitar o problema de interferências espectrais. Os tempos de medição variaram de 5.400 s a 50.000 s dependendo da meia vida e da atividade dos radioisótopos considerados. Os radioisótopos foram identificados pela meia vida e energia dos raios gama. As concentrações dos elementos nas amostras foram calculadas pelo método e a incerteza de cada determinação foi calculada considerando os erros nas contagens da amostra e padrão (De Soete et al., 1972).

O material de referência certificado CTA-VLT-2 Virginia Tobacco Leaves foi analisado para o controle da qualidade dos resultados e aplicando o mesmo procedimento experimental adotado nas análises das plantas e os resultados obtidos apresentaram desvios padrão relativos de variando de 1,9 a 11,4\% indicando uma boa precisão dos resultados Também houve uma boa 
concordância dos dados obtidos com os de valores de certificados deste material com erros relativos inferiores a $10,0 \%$.

\subsection{Determinação de $\mathrm{Hg}, \mathrm{Pb}$ e $\mathrm{Cd}$ em S. alterniflora}

\section{- Espectrometria de absorção atômica}

A Espectrometria de Absorção Atômica AAS (sigla em inglês referente a Atomic Absorption Spectrometry) é uma técnica espectro-analítica para determinação de elementos através da absorção de radiação óptica por átomos livres no estado gasoso.

Os elementos apresentam um número de elétrons associados aos seus respectivos núcleos. A configuração orbital mais estável de um átomo de qualquer elemento é chamada de "estado fundamental".

Quando a energia de um comprimento de onda específico é aplicada a um átomo, esta é absorvida e o átomo passa a apresentar uma configuração menos estável, chamada "estado excitado", sendo este o processo de absorção atômica. Uma vez que estado é instável, o átomo retornará ao estado fundamental, emitindo fóton de energia. Este processo é conhecido como emissão atômica.

O princípio fundamental desta técnica envolve a medida da absorção da intensidade da radiação eletromagnética proveniente de uma fonte de luz, por átomos gasosos no estado fundamental. Os componentes básicos de um espectrômetro incluem: fonte de radiação, atomizador, monocromador, detector e processador.

A lâmpada de absorção atômica é capaz de gerar o espectro de emissão de um elemento, o qual será direcionado a um detector passando pelo atomizador, de maneira que $0 I_{0}$ é a intensidade de radiação emitida e $I_{t}$ é a intensidade de radiação transmitida. A fonte de radiação mais comum é a lâmpada de cátodo oco, entretanto existe outro tipo de fonte de radiação específica que é a lâmpada de 
descarga sem eletrodo, que foi utilizada neste trabalho para as determinações de $\mathrm{Pb}$ e Cd. Esse tipo de lâmpada fornece intensidades radiantes.

O atomizador é um dispositivo que transforma íons ou moléculas presentes na amostra em átomos no estado fundamental para que possam absorver a radiação proveniente da lâmpada $\left(M+h v->M^{*}\right)$ e desta forma diminuir a intensidade do sinal emitido pela lâmpada e consequentemente ser utilizado na determinação da concentração do elemento de interesse.

Os atomizadores são fabricados pelos seguintes materiais:

Forno de Grafite - Espectrometria de Absorção Atomica com Atomização Eletrotérmica (GFAAS - em inglês: Graphite Furnace Atomic Absorption Spectrometry).

Geração de Vapor frio - Espectrometria de Absorção Atômica com Geração de Vapor Frio (CVAAS - em inglês: Cold Vapor Atomic Absorption Spectrometry).

Chama - Espectrometria de Absorção Atômica com Chama (FAAS - em inglês: Flame Atomic Absorption Spectrometry).

Geração de hidretos - Espectrometria de Absorção Atômica com Geração de Hidretos (HGAAS - em ingles: Hydride Generation Atomic Absorption Spectrometry).

Para este estudo foram utilizados os atomizadores forno de grafite para a determinação do $\mathrm{Pb}$ e do $\mathrm{Cd}$ e o de geração de vapor frio para $\mathrm{Hg}$ inorgânico total.

O monocromador tem a função de separar a linha espectral de interesse de várias outras linhas, por um prisma ou grade de difração. O prisma ou a grade de difração decompõe o feixe da radiação em alguns comprimentos de onda, com diferentes ângulos, assim através da fenda de saída pode-se selecionar o comprimento de onda desejado. Os sistemas de detecção mais comuns são os fotomultiplicadores que convertem energia radiante em sinal elétrico.

A lei de Lambert-Beer relaciona a concentração de átomos no estado fundamental com a absorbância: 
$A=\log I_{0} / I_{t}=\alpha l c$

onde:

A = absorbância

$\mathrm{I}_{0}=$ intensidade da radiação emitida pela fonte de luz

$\mathrm{I}_{\mathrm{t}}=$ intensidade da radiação transmitida (não absorvida)

$\alpha=$ coeficiente de absortividade molar do meio

I = espessura da célula de absorção

$\mathrm{c}=$ concentração de átomos no estado fundamental

No entanto, existem desvios na linearidade que devem ser determinados experimentalmente na análise por absorção atômica. Para isto, foi preparada uma curva de calibração que cobriu o intervalo das concentrações nas amostras. Assim, a concentração do analito é dada através da equação da reta:

$$
y=a x+b
$$

onde:

$y=$ absorbância $(A)$

$\mathrm{a}=$ coeficiente angular ou inclinação da reta

$\mathrm{x}=$ concentração do analito $(\mathrm{C})$

$b=$ coeficiente linear $\left(A_{0}\right)$

Temos que a concentração do analito é calculada de acordo com a equação 9:

$$
A=a C+A_{0}
$$


- Determinação de $\mathrm{Pb}$ e Cd por Espectrometria de Absorção Atômica com atomização em forno de grafite

O atomizador eletrotérmico do tipo forno de grafite é mais utilizado para análises elementares em níveis de $\mu \mathrm{g} \cdot \mathrm{L}^{-1}$. Neste trabalho foi utilizado 0 equipamento AAnalyst 800 da Perkin-Elmer® para a determinação de $\mathrm{Pb}$ e Cd.

Um amostrador automático introduz um pequeno volume da amostra a ser analisada (cerca de $20 \mu \mathrm{L}$ ) no interior do tubo de grafite. Após a introdução a amostra passará por etapas de secagem, pirólise e por fim será atomizada em temperaturas de até $2700^{\circ} \mathrm{C}$. Após a atomização, o tubo de grafite é aquecido novamente sem amostra para a limpeza e por fim o tubo é resfriado para a introdução de nova amostra.

- Determinação de $\mathrm{Hg}$ por Espectrometria de Absorção Atômica com geração de vapor frio

O atomizador de geração de vapor frio é aplicável somente para a determinação de mercúrio inorgânico, uma vez que este é o único elemento existente no estado de vapor na temperatura ambiente $\left(20^{\circ} \mathrm{C}-14 \mathrm{mg} \mathrm{m}^{3}\right.$ de ar) (Oliveira, 2000 apud Semmler, 2007). Para a análise de Hg inorgânico total foi utilizado este tipo de atomizador.

Neste tipo de determinação não é necessário o uso da chama para a atomização do metal, pois o mercúrio inorgânico é reduzido a vapor através da adição de um agente redutor $\left(\mathrm{SnCl}_{2}\right)$, como mostra a equação:

$$
\mathrm{Hg}^{2+}+\mathrm{Sn}^{2+} \rightarrow \mathrm{Hg}^{0}+\mathrm{Sn}^{4+}
$$

O equipamento utilizado nas análises de $\mathrm{Hg}$ foi o FIMS da Perkin-Elmer® (Flow Injection Mercury System). O programa deste equipamento já fornece todos os resultados em ng g $\mathrm{g}^{-1}$ após a determinação de acordo com a equação acima. 


\section{- Materiais de referência certificados}

Para verificar a qualidade dos procedimentos analíticos foram utilizados materiais de referência certificados:Peach Leaves SEM 1547 e Apple Leaves SRM 1515, ambos preparados pelo National Institute of Standard \& Technology - NIST (Tab. 4).

Tabela 4: Valores dos materiais de referência certificados Peach Leaves (NIST SRM 1547) e Apple Leaves (NIST SEM 1515) e valores obtidos pela técnica de Espectrometria de Absorção Atômica para os elementos $\mathrm{Pb}, \mathrm{Hg}$ e Cd.

\begin{tabular}{|c|c|c|c|c|}
\hline \multirow{3}{*}{ Elemento } & \multicolumn{4}{|c|}{ Material de Referência } \\
\hline & \multicolumn{2}{|c|}{ Peach Leaves } & \multicolumn{2}{|c|}{ Apple Leaves } \\
\hline & $\begin{array}{c}\text { Valor } \\
\text { certificado }\end{array}$ & $\begin{array}{c}\text { Valor } \\
\text { encontrado }\end{array}$ & $\begin{array}{c}\text { Valor } \\
\text { certificado }\end{array}$ & $\begin{array}{c}\text { Valor } \\
\text { encontrado }\end{array}$ \\
\hline $\mathrm{Pb}\left(\mathrm{ng} \mathrm{g}^{-1}\right)$ & $870 \pm 30$ & $802 \pm 53,92$ & $470 \pm 24$ & $243,3 \pm 7,14$ \\
\hline $\mathrm{Hg}\left(\mathrm{ng} \mathrm{g}^{-1}\right)$ & $31 \pm 7$ & $15,25 \pm 0,09$ & $44 \pm 4$ & $18,16 \pm 0,54$ \\
\hline $\mathrm{Cd}\left(\mathrm{ng} \mathrm{g}^{-1}\right)$ & $26 \pm 3$ & $29,39 \pm 0,74$ & $13 \pm 2$ & $11,22 \pm 0,67$ \\
\hline
\end{tabular}

Os materiais foram analisados simultaneamente com as amostras em ambos os métodos de Absorção Atômica, a fim de se obter a exatidão e precisão em análises. Os resultados das análises dos materiais de referência certificados pela técnica de Espectrometria Absorção Atômica indicaram boa precisão do método.

\section{Procedimento Analítico}

Para determinação dos metais $\mathrm{Hg}, \mathrm{Pb}$ e $\mathrm{Cd}$, o procedimento laboratorial de pré análise passou pelas mesmas etapas realizadas na metodologia de Análise por Ativação Neutrônica, anteriormente descritas. 
Para o procedimento analítico, foram necessários cerca de $250 \mathrm{mg}$ de farinha da gramínea, pesada em balança analítica de precisão. O pó foi transferido para frascos de teflon de $25 \mathrm{ml}$ (Savillex) e em seguida as amostras, como também os materiais de referência, foram atacados com ácido. Para a digestão das amostras foram adicionados $4 \mathrm{ml}$ de $\mathrm{HNO}_{3}$ concentrado PA Merck, o frasco depois de fechado foi levemente agitado e deixado em repouso por aproximadamente 5 horas. Ao término do descanso, foi adicionado $1 \mathrm{ml}$ de peróxido de hidrogênio 30\% (v/v) PA Merck e deixado por aproximadamente 15 horas em descanso, para em seguida sofrer a digestão final num bloco digestor a $85^{\circ} \mathrm{C}$ por 3 horas. Após o período de aquecimento, os frascos foram retirados do bloco digestor, o volume de cada amostra foi calibrado com água Milli $Q$ e o material digerido foi homogeneizado.

A digestão de todas as amostras foi similar para determinação de $\mathrm{Hg}, \mathrm{Pb}$ e Cd conforme o procedimento analítico supracitado.

O material digerido para determinação de $\mathrm{Pb}$ e $\mathrm{Cd}$ foi analisado por espectrometria de absorção atômica com atomização eletrotérmica - Forno de Grafite (AAnalyst 800 - Perkin-Elmer), enquanto a determinação do $\mathrm{Hg}$ foi realizada por espectrometria de Absorção Atômica com Geração de Vapor a Frio (equipamento de CV AAS - FIMS Perkin-Elmer, Flow Injection Mercury System) no Laboratório de Análise por Ativação Neutrônica (LAN-CRPQ) - do Instituto de Pesquisas Energéticas e Nucleares IPEN/CNEN, com o auxílio e supervisão da Dra Deborah Fávaro. 


\section{RESULTADOS E DISCUSSÃO}

\section{Dados Climatológicos}

As coletas das amostras dos campos de $S$. alterniflora foram realizadas nos períodos de verão de 2009 e 2010 e inverno de 2009. A pluviosidade foi adquirida com base nos dados da estação Meteorológica da Base Sul Antônio de Paiva Neto em Cananéia que registrou no mês de fevereiro de 2009 (Figura 9a), estação de verão, registrou uma precipitação mensal de $486,6 \mathrm{~mm}$ de chuva e, $131,4 \mathrm{~mm}$ acumulados até o dia de início das coletas. Durante o período de amostragem, foi registrado respectivamente, 1,3;29,2 e 1,3 mm de chuva nos os dias 11, 12 e 13 de fevereiro de 2009 sendo que, no dia 12 ocorreu a maior incidência de chuva, não houve coleta da gramínea. De acordo com Silva (1989) ao monitorar a série temporal de 1956 a 1985, o mês de março (verão) foi identificado como o mais chuvoso (328 mm). No ano de 2009, o mês de março foi mais úmido que aqueles monitorados na série de Silva (op. cit.).

A temperatura, no período de verão, teve a média de $26,49^{\circ} \mathrm{C}$, mínima de $23,33^{\circ} \mathrm{C}$ e máxima de $28,93^{\circ} \mathrm{C}$. Na Figura 9 , pode ser observada uma queda de temperatura nos dias de coleta juntamente com a chegada da chuva. Dados de 1956-1980 registrados pelo IOUSP em Cananéia (Schaeffer-Novelli et al., 1990) mostram valor médio anual de $21,2^{\circ} \mathrm{C}$, e a média do mês mais quente (janeiro) foi de $24,5^{\circ} \mathrm{C}$. Diante destes dados, os valores obtidos no trabalho atual foram mais altos.

No inverno de 2009, o mês de agosto apresentou pluviosidade de 80,1 $\mathrm{mm}$ de chuva, com um valor acumulado até o início das atividades de coleta de $21,7 \mathrm{~mm}$ e durante o período de amostragem, a pluviosidade registrada foi respectivamente de 2,4; 36; 0,4 e $4 \mathrm{~mm}$ de chuva nos dias 19; 20; 21 e 22 de agosto. A pluviosidade registrada nos meses de inverno de 2009 foi similar à encontrada por Silva (1989), em que o mês de agosto (o mais seco) apresentou $80 \mathrm{~mm}$ de chuva, de acordo com a série temporal de 1956 a 1885. 
As coletas da gramínea, no inverno, ocorreram somente nos dias 19 e 22 agosto, dias em que as temperaturas máximas do ar foram de 21,8 e $17,6{ }^{\circ} \mathrm{C}$, respectivamente. A média do mês foi de $19,8^{\circ} \mathrm{C}$, com mínima de $15,9^{\circ} \mathrm{C}$ e máxima de $22,6^{\circ} \mathrm{C}$. Nesse período ocorreu uma seqüência de 9 dias consecutivos de chuva e temperaturas mais baixas, como pode ser visualizado na Figura 9. Nesse ano, no mês de agosto, as temperaturas estiveram acima da média de temperatura do mês mais frio (julho) que é $7,8^{\circ} \mathrm{C}$. A temperatura mais baixa registrada foi de $2,4^{\circ} \mathrm{C}$, em julho de 1975 , de acordo com os dados de 1956-1980, monitorados pelo IOUSP (Schaeffer-Novelli et al., 1990).

A amostragem do verão de 2010 ocorreu no mês de março, considerado mês mais chuvoso do ano segundo o estudo da seqüência de dados de Silva (1989). Houve dificuldade de obtenção dos dados de precipitação diária além da precipitação total. O mês de fevereiro de 2010 acumulou 235,2 $\mathrm{mm}$ de chuva, mostrou a temperatura média de $29,04^{\circ} \mathrm{C}$, mínima e máxima de $23,9^{\circ} \mathrm{C}$ e $33,7^{\circ} \mathrm{C}$, respectivamente.

$\mathrm{Na}$ região de estudo o clima é classificado como temperado úmido e os dois verões amostrados foram quentes e úmidos, contudo o verão de 2009 foi mais úmido e frio que o verão de 2010. No caso do inverno, em 2009 a amostragem representou melhor o período, seco e frio. 

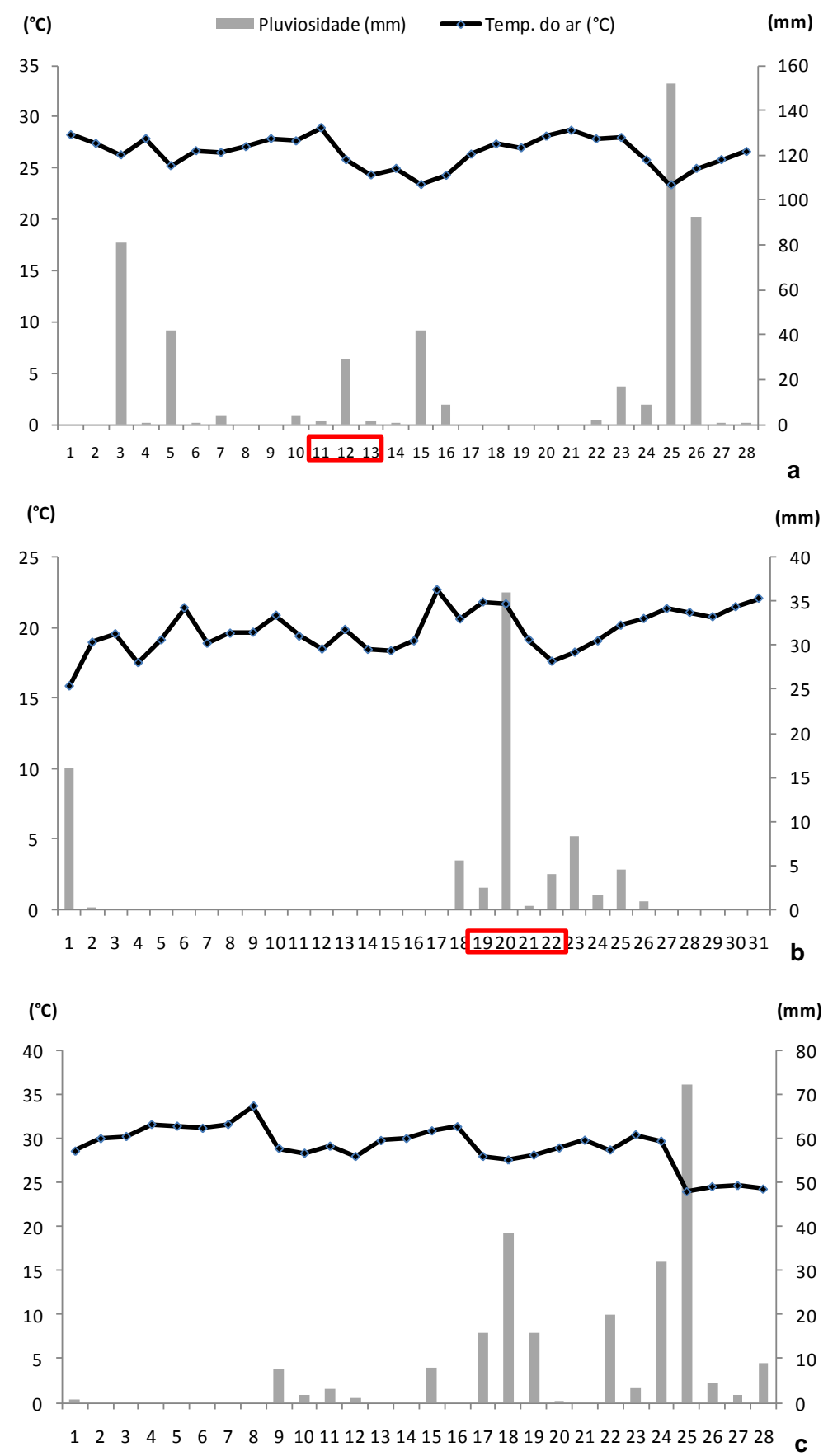

Figura 9. Variações diárias de temperatura do $\operatorname{ar}\left({ }^{\circ} \mathrm{C}\right)$ e pluviosidade $(\mathrm{mm})$ nos períodos trabalhados, fevereiro de 2009 (a), agosto de 2009 (b) e fevereiro de 2010 (c) referente à estação meteorológica IOUSP da base de Cananéia. 


\section{Dados Hidrológicos}

\subsection{Maré}

A altura de maré e o momento de coleta $S$. alterniflora no verão e inverno de 2009 e verão de 2010 estão apresentados na Figura 10.

No verão de 2009, as amostras de S. alterniflora foram coletadas nos dias 11 de fevereiro em Cananéia e no dia 13 em Iguape. A maré apresentou perfil de sizígia nos dois dias com altura máxima de $1,4 \mathrm{~m}$. A amostragem do campo de $S$. alterniflora em Cananéia ocorreu com as gramíneas semi-submersas, enquanto em Iguape, os campos estavam emersos.

As coletas de inverno 2009 correram nos dias 19 e 22 de agosto, e a maré apresentou perfil de sizígia. A coleta ocorreu em momento de baixamar nas duas regiões e os campos estavam emersos.

As coletas de verão de 2010 ocorreram nos dias 15 e 17 de março e a maré apresentou um perfil de sizígia com preamar a 1,5m no primeiro dia, sendo que nos momentos de coleta de $\mathrm{S}$. alterniflora, a maré estava baixa e os campos estavam totalmente expostos nos dois setores de estudo. 

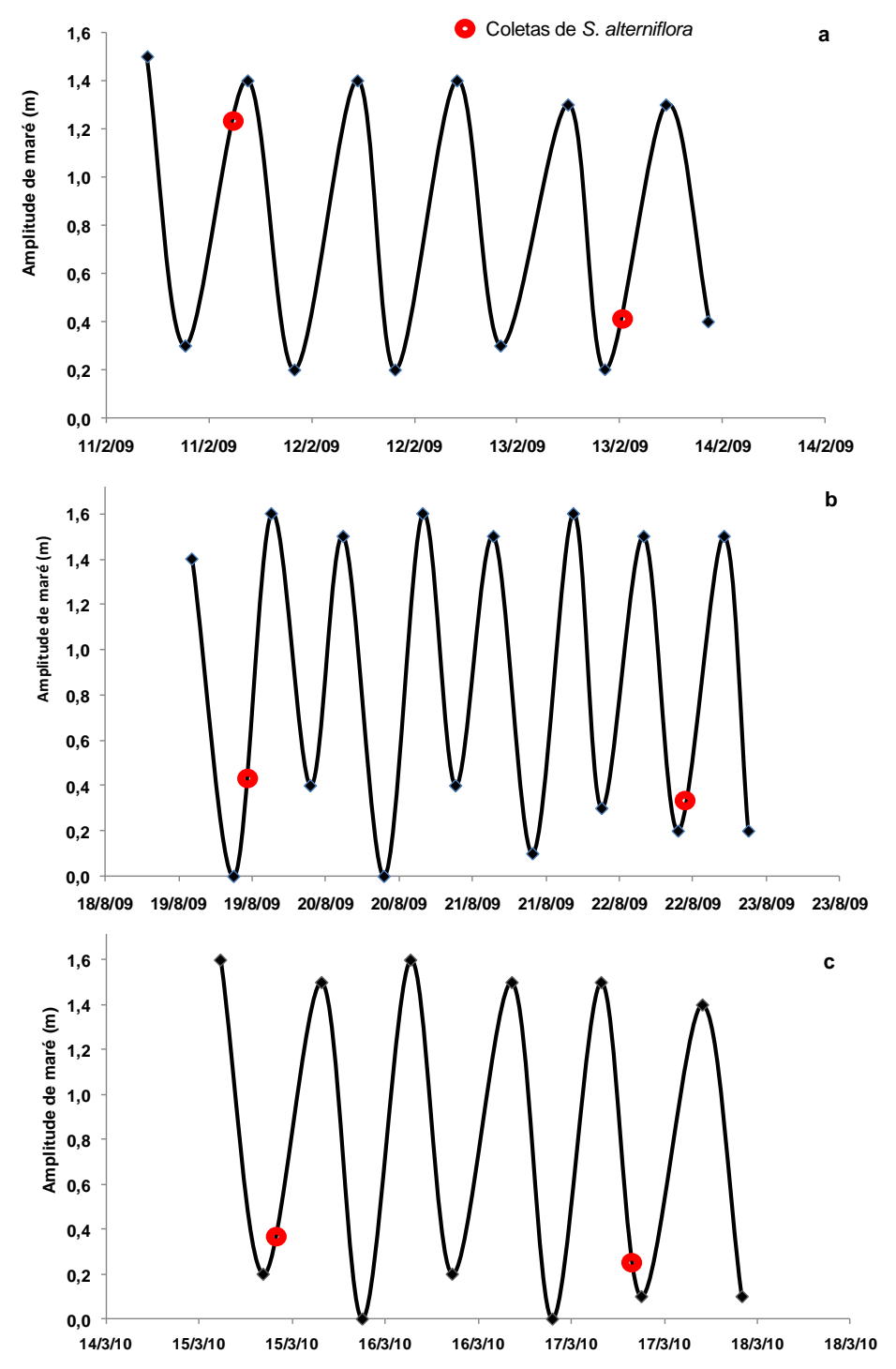

Figura 10. Variação da altura de maré nos dias de coleta hidroquímica e nos momentos de coleta da Spartina alterniflora nas 3 campanhas: verão de 2009 (a); inverno de 2009 (b) e verão de 2010 (c).

Analisando séries de dados temporais do Mar de Cananéia, Miyao \& Harari (1989) apresentaram um estudo da maré e das correntes de maré, onde ficou demonstrado que a circulação nessa região é predominantemente gerada pela maré semi-diurna, com valores extremos de 0,83 $\mathrm{m}$ e 0,13 $\mathrm{m}$ para as amplitudes de sizígia e quadratura, respectivamente. O presente trabalho mostrou a ação da onda de maré semi-diurna, na mesma amplitude que os autores citados. 
A maré é o principal fator hidrodinâmico que atua nos campos de Spartina que devido o comportamento semi-diurno da onda de maré, sofrem inundação e exposição total de suas estruturas duas vezes ao dia. As plantas herbáceas que normalmente colonizam as faixas da franja de manguezal estão adaptadas à este estresse hídrico, ora submersas interagindo com a água característica do corpo hídrico local, ora emersas mostrando sua adaptação às alterações de exposição, temperatura, salinidade e variação nas características sedimentares que estão envolvidas. A maré, nessa faixa estuarina de marisma depende muito da topografia dos bancos sedimentares, dos bancos de halófitas e, vice-versa, de forma que as características dos bancos da gramínea representam as taxas de transferência de material particulado em suspensão, de matéria orgânica e nutrientes, os quais variam juntamente com a maré. Assim, a componente biológica está diretamente relacionada ao gradiente físico-químico impresso pela microtopografia, sob influência das marés, onde as espécies de vegetais superiores colonizam o substrato segundo suas exigências ecofisiológicas (Thom, 1982).

Recentemente, Schaeffer-Novelli et al. (2000) sugeriram dois tipos fisiográficos principais (franja e bacia) e três sub-tipos (ilhota, anão e arbustivo). $\mathrm{O}$ critério utilizado pelos autores para descrever esses tipos principais foi a cinética do movimento da água e o hidroperíodo, segundo o qual o ambiente estaria sujeito a maior ou menor fluxo de água, dentro do sistema. Assim sendo, o tipo franja possui maior intercâmbio de água, enquanto que o tipo bacia possui baixo hidrodinamismo. 


\subsection{Dados hidrobioquímicos da água de superfície do corpo hídrico e da água adjacente aos campos de $S$. alterniflora nos dois setores do sistema}

Os valores de temperatura, salinidade, oxigênio dissolvido, $\mathrm{pH}$, nutrientes (fosfato e silicato), matéria orgânica, material em suspensão e pigmentos da água de superfície do corpo hídrico e da água adjacente aos campos de $S$. alterniflora, foram amostrados nas duas regiões, Cananéia e lguape, e nos 3 períodos trabalhados, verão e inverno de 2009 e verão de 2010 e, encontram-se nas tabelas 5,6 e 7 .

\section{Verão 2009}

Em Cananéia, a temperatura do corpo hídrico $(\mathrm{CH})$ (Tabela 5; Figura 11-a) variou de 28,82 a $30,70^{\circ} \mathrm{C}$, sendo que no período de amostragem dos campos Ponta do Arrozal (PA) e llha Comprida (IC), a temperatura dos mesmos foram de 29,20 e $28,90^{\circ} \mathrm{C}$ respectivamente, enquanto no $\mathrm{CH}$, no mesmo horário, a temperatura foi de $28,82^{\circ} \mathrm{C}$ mostrando que o campo IC apresentou temperatura mais próxima ao $\mathrm{CH}$.

Adaime (1978) encontrou no verão de 1974 (janeiro e março) em uma estação fixa, temperaturas entre $25^{\circ} \mathrm{C}$ e $30^{\circ} \mathrm{C}$, observadas em baixamar. Braga (1995) observou valores de temperatura no verão 1992, em ponto fixo variando de 25,15 a $28,11^{\circ} \mathrm{C}$. Pisetta (2010) encontrou no verão de 2008 , a temperatura da água entre $28,1^{\circ} \mathrm{C}$ às $9 \mathrm{~h}$ e $27,25^{\circ} \mathrm{C}$ às $19 \mathrm{~h}$. Os valores altos no corpo hídrico no verão, durante um ciclo de maré são confirmados por vários autores e, temperaturas ligeiramente mais altas podem ser observadas em local com menor profundidade e hidrodinâmica como é o caso dos campos de $S$. alterniflora.

Em Iguape, a temperatura de $\mathrm{CH}$ observada por 13h (Fig. 11-b) mostrou valores de 26,55 a $27,20^{\circ} \mathrm{C}$ sendo que no horário de coleta (11-12h) foi de 28,80 a $26,82^{\circ} \mathrm{C}$ enquanto que, junto aos campos de $S$. alternflora foram de 28,35 e $26,80^{\circ} \mathrm{C}$ em Mar Pequeno (MP) e Barra do Icapara (BI) respectivamente, 
mostrando o aquecimento relativo em MP e uma temperatura bem similar ao $\mathrm{CH}$ em Bl.

Em janeiro de 2001, Barrera-Alba et al. (2007) observaram valores de temperatura da água em três pontos: no Valo Grande $\left(23,8^{\circ} \mathrm{C}\right)$, na estação da Ponte $\left(24,1^{\circ} \mathrm{C}\right)$ e na estação da Barra de Icapara $\left(25,5^{\circ} \mathrm{C}\right)$. Enquanto Pisetta (2010) obteve valores no Mar de Iguape, no verão de 2008 temperaturas que oscilaram entre $27,61^{\circ} \mathrm{C}$ (superfície, 9h) e $28,53^{\circ} \mathrm{C}$ (superfície 16h). Enquanto na estação do Valo Grande, as temperaturas variaram entre $27,13^{\circ} \mathrm{C}(8 \mathrm{~h})$ e $27,51^{\circ} \mathrm{C}$ (17h). 
Tabela 5. Dados hidrobioquímicos da campanha de fevereiro de 2009 (verão), nos pontos dos setores norte e sul do complexo Estuarino-Lagunar Cananéia-Iguape e dos campos de S. alterniflora, sendo CH (corpo hídrico); PA (Ponta do Arrozal); MP (Mar pequeno); BI (Barra do Icapara).

\begin{tabular}{|c|c|c|c|c|c|c|c|c|c|c|c|c|}
\hline \multicolumn{2}{|r|}{ Local } & Horário & $\begin{array}{c}\mathrm{T} \\
\left({ }^{\circ} \mathrm{C}\right)\end{array}$ & $\begin{array}{c}\text { Sal } \\
\text { (UPS) }\end{array}$ & $\begin{array}{c}\text { OD } \\
\left(m L L^{-1}\right)\end{array}$ & $\mathrm{pH}$ & $\begin{array}{c}\text { Silicato } \\
(\mu \mathrm{M})\end{array}$ & $\begin{array}{c}\text { Fosfato } \\
(\mu \mathrm{M})\end{array}$ & $\begin{array}{c}\text { MPS } \\
\left(\mathrm{mg} \mathrm{L}^{-1}\right)\end{array}$ & $\begin{array}{c}\text { \%MOS } \\
\text { no MPS }\end{array}$ & $\begin{array}{c}\mathrm{Cl}-a \\
\left(\mathrm{mg} \mathrm{m}^{-3}\right)\end{array}$ & $\begin{array}{c}\text { Feo } \\
\left(\mathrm{mg} \mathrm{m}^{-3}\right)\end{array}$ \\
\hline \multirow{10}{*}{  } & \multirow{7}{*}{$\begin{array}{c}\mathrm{CH} \\
19 / 08 / 2009\end{array}$} & 08:00 & 20.46 & 24.95 & 4.84 & 8.39 & 47.70 & 0.61 & 56.4 & 35.2 & 3.72 & 4.27 \\
\hline & & $10: 00$ & 20.80 & 22.19 & 4.76 & 8.23 & 63.25 & 0.65 & 44.0 & 35.4 & 2.05 & 0.12 \\
\hline & & $12: 00$ & 21.84 & 21.72 & 5.30 & 8.29 & 63.20 & 0.92 & 45.3 & 39.7 & 1.94 & 1.93 \\
\hline & & $14: 00$ & 20.79 & 29.92 & 5.14 & 8.42 & 23.64 & 0.45 & 73.7 & 32.2 & 4.15 & 21.97 \\
\hline & & $16: 00$ & 20.41 & 32.28 & 5.11 & 8.50 & 14.74 & 0.39 & 82.2 & 26.2 & 4.64 & 5.64 \\
\hline & & $18: 00$ & 20.51 & 29.74 & 5.11 & 8.47 & 24.96 & 0.52 & 70.7 & 36.5 & 2.88 & 3.03 \\
\hline & & $20: 00$ & 20.80 & 27.01 & 4.94 & 8.42 & 37.04 & 0.68 & 84.0 & 38.1 & 2.13 & 4.07 \\
\hline & \multicolumn{2}{|c|}{ Média } & 20.80 & 26.83 & 5.03 & 8.39 & 39.22 & 0.60 & 65.19 & 34.74 & 3.07 & 5.86 \\
\hline & $\mathrm{PA}$ & $12: 00$ & 23.20 & 21.72 & 5.12 & 8.42 & 69.26 & 0.92 & 77.71 & 31.25 & 7.44 & 8.78 \\
\hline & IC & $11: 00$ & 24.50 & 26.62 & 5.15 & 8.24 & 22.73 & 0.92 & 94.00 & 27.05 & 3.98 & 2.52 \\
\hline \multirow{10}{*}{$\begin{array}{l}\text { 음 } \\
\text { 음 } \\
\text { 으 }\end{array}$} & \multirow{7}{*}{$\begin{array}{c}\mathrm{CH} \\
22 / 08 / 2009\end{array}$} & 07:00 & 20.23 & 2.98 & 5.38 & 7.45 & 136.85 & 2.15 & 25.1 & 27.4 & 4.70 & 6.36 \\
\hline & & 09:00 & 20.10 & 0.78 & 5.48 & 7.19 & 186.93 & 2.73 & 33.1 & 27.5 & 7.33 & 12.73 \\
\hline & & 11:00 & 18.86 & 0.36 & 5.63 & 7.02 & 149.26 & 3.13 & 15.1 & 32.4 & 7.50 & 13.01 \\
\hline & & $13: 00$ & 20.48 & 0.55 & 5.59 & 7.29 & 143.13 & 2.90 & 15.6 & 42.9 & 8.04 & 11.72 \\
\hline & & $15: 00$ & 20.49 & 1.48 & 5.46 & 7.28 & 155.69 & 2.43 & 33.8 & 26.0 & 5.93 & 6.32 \\
\hline & & $17: 00$ & 18.78 & 5.17 & 5.42 & 7.66 & 200.36 & 2.00 & 23.8 & 39.3 & 2.74 & 4.00 \\
\hline & & $19: 00$ & 20.50 & 3.28 & 5.64 & 7.53 & 193.35 & 2.12 & 58.7 & 80.3 & 2.42 & 4.45 \\
\hline & \multicolumn{2}{|c|}{ Média } & 19.92 & 2.08 & 5.51 & 7.35 & 166.51 & 2.49 & 29.30 & 39.38 & 5.52 & 8.37 \\
\hline & MP & $12: 00$ & 17.90 & 1.01 & 5.17 & 7.16 & 150.63 & 1.78 & 91.00 & 24.18 & 13.95 & 17.32 \\
\hline & $\mathrm{BI}$ & $10: 00$ & 20.25 & 6.93 & 5.68 & 7.88 & 163.27 & 1.98 & 73.33 & 29.31 & 6.64 & 7.25 \\
\hline
\end{tabular}

Em negrito, período de coleta similar do corpo hídrico $(\mathrm{CH})$ com a coleta nos campos de Spartina alterniflora. 
De um modo geral, os valores observados no estudo atual mostram a capacidade da água em alguns campos de $S$. alterniflora apresentaram valores de temperatura maiores que os observados no corpo hídrico adjacente, ou seja, mais distante das bordas, revelando a ação das propriedades térmicas na baixa coluna de água e, da baixa hidrodinâmica nos campos, enquanto que o campo BI revelou a ação da presença da água de mar aberto, que muitas vezes em momento de maré enchente, pôde resfriar as águas junto à Barra do Icapara.

Observando a estrutura térmica entre os dois setores do complexo estuarino-lagunar Cananéia-Iguape (CELCl), na amostragem de verão de 2009, Cananéia mostrou temperaturas superiores à lguape, a temperatura mínima em Cananéia do $\mathrm{CH}$ foi de $28,6^{\circ} \mathrm{C}$, enquanto em Iguape, a temperatura máxima do $\mathrm{CH}$ foi $27,2^{\circ} \mathrm{C}$, o que se pode inferir na influência fluvial do canal artificial do Valo Grande no sistema hídrico norte, com maior aporte de água continental fria para o sistema devido o período chuvoso do verão, além disso, diferenças climáticas entre os dias de amostragem nos dois setores ocorreram.

A salinidade (Tab. 5 e Fig. 11c) no verão em Cananéia mostrou valores entre 17,97 e 31,04, sendo que na hora da amostragem dos campos de gramínea a salinidade do $\mathrm{CH}$ foi de 29,12 (16h) e os campos, PA e IC mostraram valores de 21,72 e 26,62 respectivamente, o que mostra que PA apresentou condições halinas semelhantes ao $\mathrm{CH}$ e IC, a salinidade foi superior ao $\mathrm{CH}$. Na PA, Adaime (1978) encontrou valores de salinidade de 21,5 na baixamar e 18,31 na preamar de janeiro do ano de 1974 e 9,84 na baixa-mar e 10,34 na preamar de março do mesmo ano, ou seja, valores inferiores aos encontrados no presente estudo.

Braga (1995) e Braga \& Chiozzini (2005) ao estudarem o CELCI em duas situações, em 1992 com o Valo Grande aberto e em 2005 com o canal fechado, encontraram em Cananéia ( 70Km do Valo Grande) salinidade média de 31,94 para o primeiro período e 26,41 no segundo, havendo assim, uma queda dos valores halinos no setor sul com a influência do sistema norte. Pisetta (2010) obteve no verão de 2008, no Mar de Cananéia, salinidade variando entre 17,69 (18h) e 20,95 (9h) com média espaço-temporal de 18,38. 

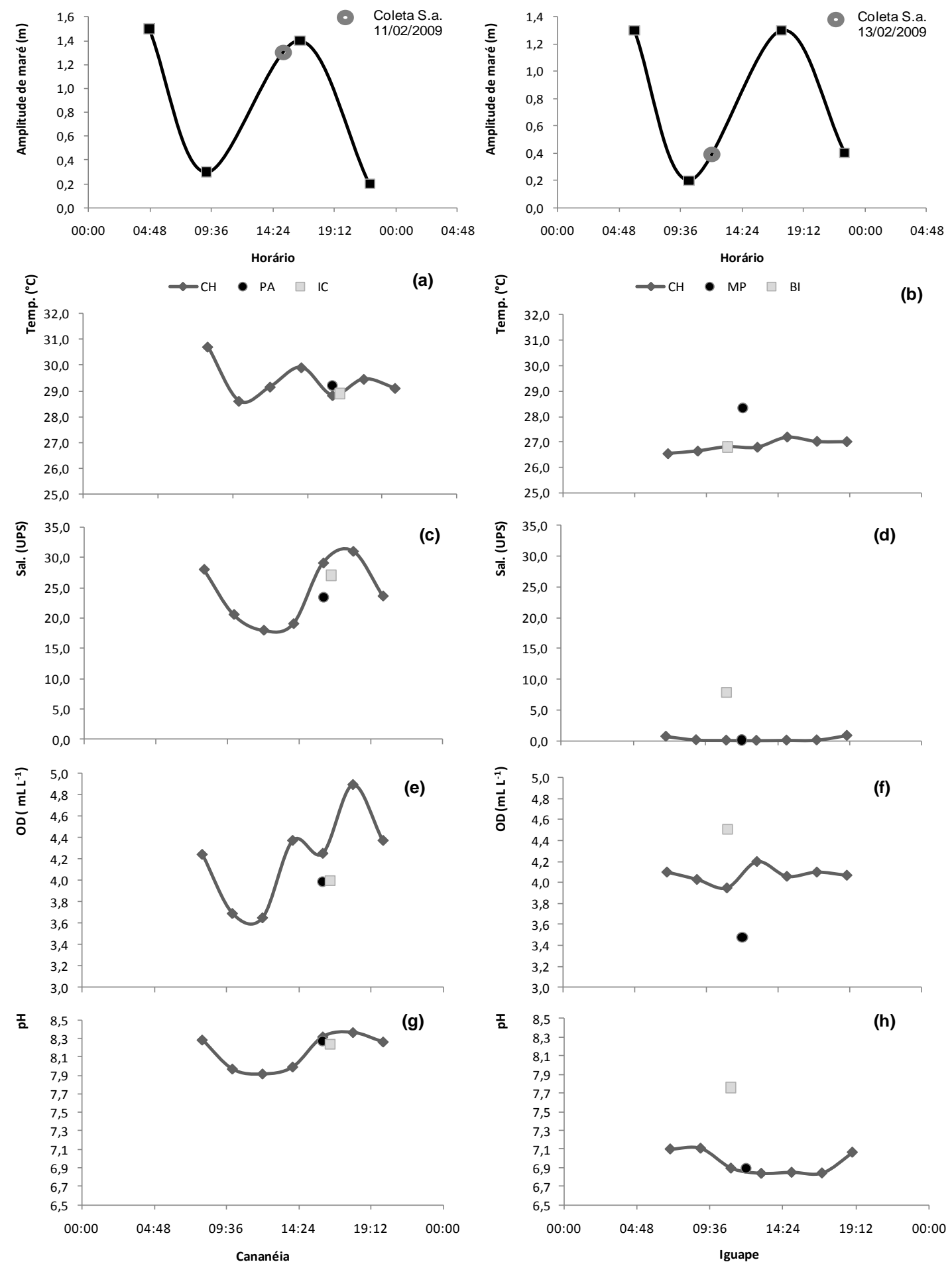

Figura 11. Variação temporal dos parâmetros físicos e químicos ao longo de um período de maré (13h) no período do verão de 2009, nos dois setores, Cananéia (esquerda) e lguape (direita). ( $\diamond$ losango preto refere-se ao corpo hídrico nos dois setores e $(\boldsymbol{\square})$ quadrado $(\mathrm{IC}),(\bullet)$ esfera $(\mathrm{PA}),(\boldsymbol{\bullet})$ quadrado $(\mathrm{BI})$ e $(\bullet)$ esfera (MP) para os campos de $S$. alterniflora, 
Assim, nos verões em Cananéia, observando essa alteração de cenários e os registros históricos, de um modo geral, aparentemente a salinidade vem se reduzindo ao longo dos anos, considerando que há diferença de pluviosidade entre os anos dependendo também dos efeitos dos fenômenos globais atuantes na região como El Niño e La Niña.

Em Iguape, (Fig. 11d) os valores de salinidade, foram todos muito baixos, $(<1)$ sendo que o único valor mais alto $(7,83-11 \mathrm{~h})$ observado foi relativo ao campo de $\mathrm{BI}$, devido à sua localização junto à Barra de Icapara, e com isso estar sujeito a maior influência marinha, uma vez que o sistema interno está sob forte domínio de água doce (Resolução CONAMA 375/2005).

Miyao (1986) mostrou dados de estação fixa no Mar Pequeno (Iguape) em janeiro de 1980, com salinidade média de 18. Em janeiro de 2001, Barrera-Alba et al. (2007) encontraram em 3 pontos salinidade 0,00 em Iguape junto ao Valo Grande, 0,90 na Ponte e 18,4 na Barra de Icapara. Já Pisetta (2010) em experimento no Mar de Iguape no verão de 2008, também em estação fixa, observou valores de salinidade entre 0 e 29.

Considerando as condições junto aos campos, segundo Bunt et al. (1982), o padrão da salinidade da água intersticial ao longo da zona entremarés é influenciado pelo corpo d'água adjacente (rios, estuários, baía, dentre outros), pluviosidade, drenagem terrestre (runoff) e também, pela percolação da água no sedimento. Nas zonas mais baixas, a salinidade é praticamente a mesma da água das marés, podendo chegar a 35 (água do mar) ou abaixo desse valor em sistemas onde há forte descarga fluvial.

Os dados de oxigênio dissolvido (Tabela 5 e Fig. 11 e-f) obtidos no verão 2009 mostrou valores sempre superiores a $4 \mathrm{~mL} \mathrm{~L}^{-1}$ exceto nos horários 10-12h em Cananéia e $11 \mathrm{~h}$ em Iguape ambos no $\mathrm{CH}$ e relativos ao momento de maré baixa, o que é explicado pela diminuição da coluna d'água e aproximação dos processos de fundo que naturalmente consomem OD. Valor baixo também foi observado no campo PA (Cananéia) e MP já perto de lguape, coletados as 16 e $12 \mathrm{~h}$ respectivamente, também em maré baixa. Normalmente, quando os campos 
de $S$. alterniflora estão expostos para coleta, a água junto ao campo, embora mexida, encontra-se bastante carregada de matéria orgânica, o que consome oxigênio.

No caso do pH (Tabela 5 e Fig. $11 \mathrm{~g}$-h) os maiores valores foram observados onde a água do mar se faz mais presente, ou seja no setor sul e houve também reprodução destes altos valores na coleta da água junto aos campos de $S$. alterniflora, ou seja, em PA e IC, respectivamente coletados as 16 e 16:30h, quando a maré já estava subindo. Valores mais baixos foram observados em Iguape, onde a salinidade é muito menor e as características tampão da água diminuem. Os campos amostrados em Iguape, sobretudo MP mostrou valor baixo, enquanto $\mathrm{BI}$, mais uma vez, destacando a influência marinha, mostrou o maior valor em Iguape, amostrado em condição de maré baixa.

O silicato (Tabela 5 e Fig. 12 a-b) mostrou valores extremamente altos no setor de Iguape, evidenciando o aporte de material terrestre, com grande teor de silicato também na forma dissolvida, pois os valores foram em sua maioria, superiores a $100 \mu \mathrm{M}$, o que ocorreu também nos campos de $S$. alterniflora. No caso de Cananéia, os valores também podem ser considerados altos, mas apresentaram uma faixa de 7,16 a 60,71 no $\mathrm{CH}$, havendo apenas destaque do valor de IC, cujo valor de silicato foi muito alto $(131,91$ - 16:30h) para o setor, o que deve estar associado a algum aporte de água intersticial ou de ressuspensão de material.

Observando as concentrações de fosfato (Tabela 5 e Fig.12 c-d) no setor sul (Cananéia), os valores oscilaram de 0,19 a 1,10 uM e o campo IC também apresentou alto fosfato $(2,72 \mathrm{uM}-16: 30 \mathrm{~h})$ o que corrobora com algum aporte de origem ligada ao sedimento ou solo, neste momento. Os valores obtidos no setor norte, mostraram o enriquecimento das águas $(\mathrm{CH})$ devido ao aporte pelo Rio Ribeira, pois todos os valores estiveram acima de 1,00 uM e os campos também mostraram valor similar, não tendo uma intrusão forte como ocorreu em IC. 

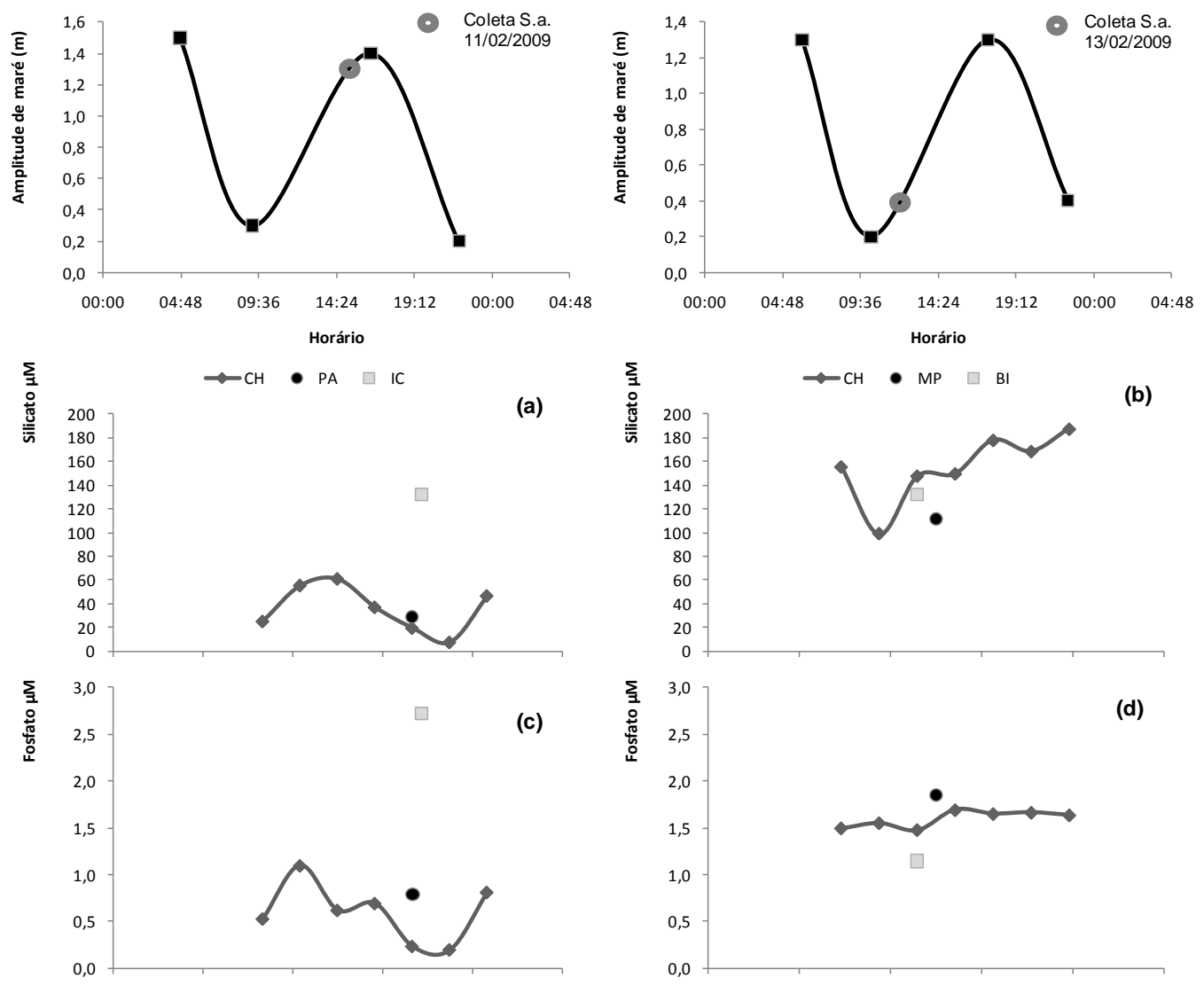

$\sum$
$\frac{1}{0}$
0
$\frac{0}{5}$
0
0

(d)
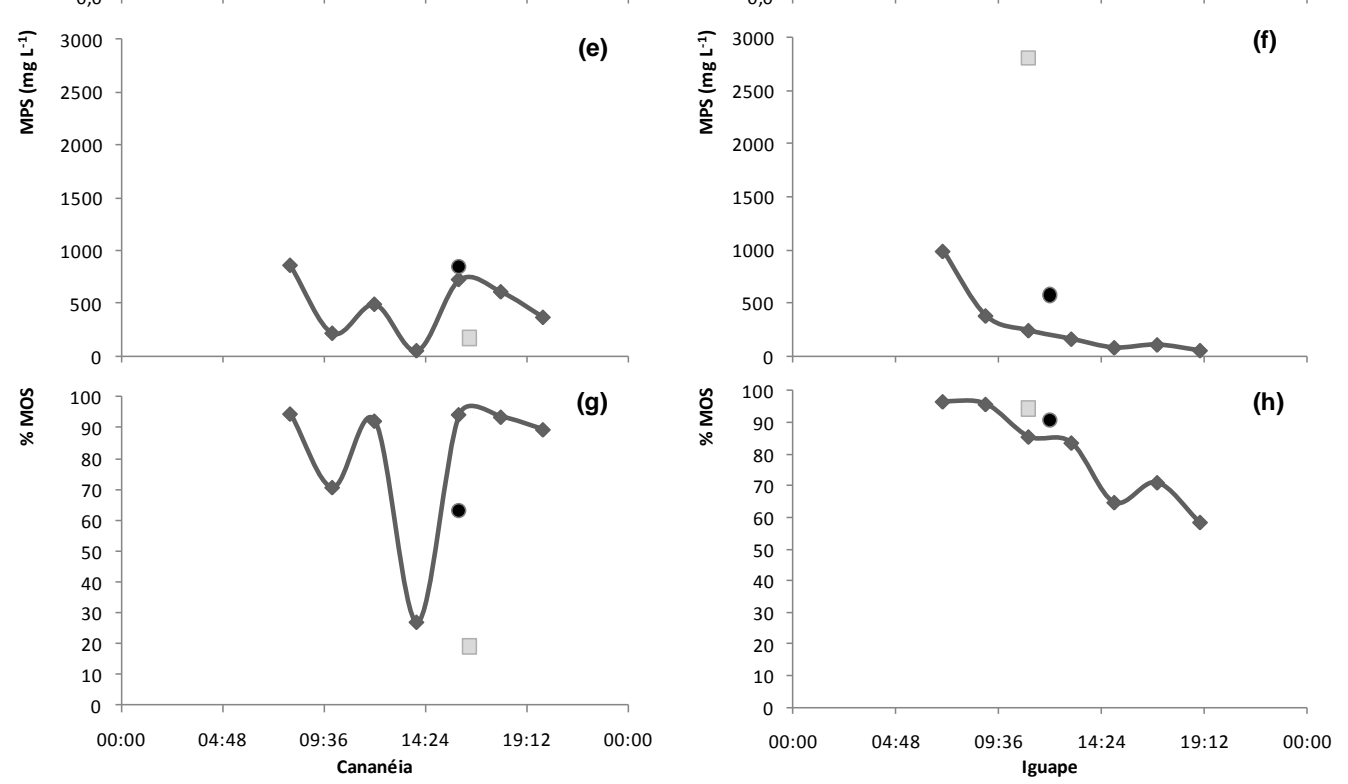

Figura 12: Variação temporal do silicato, fosfato, MPS e \%MOS ao longo de um ciclo de maré no período do verão de 2009, em dois setores, Cananéia (esquerda) e Iguape (direita). Refere-se ao corpo hídrico ( $\downarrow$ ) losango preto para os dois setores,

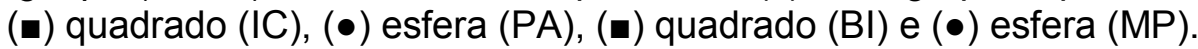


Braga \& Chiozzini (2005) trabalhando nos verões de 1992 e 2005 em que o canal do Valo Grande encontrava-se fechado e aberto, verificaram teores médio de silicato de $31,11 \mu \mathrm{M}$ para o primeiro período e $24,55 \mu \mathrm{M}$, no segundo. Para essa região, Maluf (2010) ao estudar os teores de silicato dissolvido em estações fixas, registrou para o outono de 2007 a concentração mediana de 9,08 $\mu \mathrm{M}$ na água superficial e na primavera do mesmo ano o teor mediano de 11,02 $\mu \mathrm{M}$.

Braga (1995) observou valores de fosfato no verão 1992 em estação fixa em Cananéia, variando de 0,10 a 0,53 uM, na faixa da maioria dos valores observados no atual trabalho.

O movimento em pulso de nutrientes corresponde a formas de enriquecimento do sistema estuarino que mantém diversas formas de vida, evitando processos de eutrofização (segundo com. Pessoal de Braga)

O material particulado em suspensão (Tabela 5 e Fig. 12 e-f) exibiu valor médio maior em Cananéia que em Iguape, o que corresponde a um paradoxo, em relação a cor da água, pois as águas mais barrentas se encontram ao norte, assim os valores maiores podem ser explicados pela qualidade do material em suspensão, que no norte é composto, além da fração orgânica por material pelítico enquanto ao sul, a fração inorgânica é mais graúda (com. Pessoal, Braga, E. S). Quanto ao material observado nos campos de $S$. alterniflora, uma carga importante de material está presente em PA (Cananéia) e, sobretudo, em BI (Iguape), que foi exagerado. O esforço para pouco remexer as águas do entorno do campo, no momento de amostragem ocorre, porém nem sempre há total isenção desta interferência.

Quanto à fração de material orgânico em suspensão presente em $\mathrm{CH}$, observou-se sempre uma fração importante nos dois setores, sempre acima de $50 \%$, com exceção feita para o momento de $14 \mathrm{~h}$ em Cananéia, em maré alta, mostrando a menor carga de orgânicos, e o campo IC mostrou também um valor muito baixo (19,06\% - 16:30h). O sistema estuarino possui importante carga de material orgânico tanto na fração particulada, como dissolvida, e o momento onde a presença de água salina é maior, pode ocorrer diminuição desta carga. Em 
relação aos campos de $S$. alterniflora, os valores de $M O$ sempre estiveram compondo mais de $90 \%$ do material particulado em suspensão.

Braga (1995) observou valores de material particulado em suspensão em Cananéia em uma estação fixa variando de 24,4 a 42,0, em 1992 quando o Valo Grande estava fechado.

No Mar de Iguape, Pisetta (2010) apresentou o valor máximo de 217,4 mg $\mathrm{L}^{-1}$ (fundo, 17h) e o mínimo $12,9 \mathrm{mg}^{\mathrm{L}}{ }^{-1}$ (meia água, 18h). Estes valores são inferiores ao valor médio encontrado no presente trabalho.

Observando os pigmentos na água, obteve-se maiores concentrações de clorofila a, (Tabela 5 e Fig. 13 a-b) o pigmento mais abundante também em algas que compõem o fitoplâncton, na região de Cananéia, sistema que preserva características estuarinas. E valores muito altos foram observados junto aos campos de gramínea no setor sul. A riqueza em clorofila no setor sul é conhecida. Os teores em feopigmentos (Tabela 5 e Fig. $13 \mathrm{c}$-d) mostram valores aceitáveis que indicam uma fração de clorofila decomposta, enquanto em Iguape, os valores de clorofila $a$, foram menores, muito possivelmente devido à qualidade de luz no sistema e, os valores de feopigmentos foram menores. No caso dos campos de $S$. alterniflora localizados em lguape, os valores de pigmentos também foram menores. Há de se fazer uma observação quanto às diferenças entre as comunidades de fitoplâncton que estão presentes no setor norte do sistema em relação ao sul, devido às características halinas, entre outras.

Braga (1995) observou valor máximo de $22,4 \mathrm{mg} \mathrm{m}^{-3}$ de Clorofila a em Cananéia, em estação fixa realizada em 1992.

Barrera-Alba et al. (2007) obtiveram concentrações de clorofila a na região de Iguape dispondo de valores nos pontos amostrais do Valo Grande com 2,74 mg $\mathrm{m}^{-3}$, no banco do Caranguejo com 3,07 $\mathrm{mg} \mathrm{m}^{-3}$, na Ponte com 4,35 $\mathrm{mg} \mathrm{m}^{-3}$ e na Barra de Icapara com a concentração de $5,71 \mathrm{mg} \mathrm{m}^{-3}$.

Observando a diferença entre os dois setores do $\mathrm{CELCl}$, o setor sul apresentou níveis de clorofila a no $\mathrm{CH}$ muito superiores aos encontrados no $\mathrm{CH}$ Norte, como também na água dos campos de Spartina. 



Figura 13. Variação temporal da clorofila a e feofitina ao longo de um ciclo de maré no período do verão de 2009 em dois setores, Cananéia (esquerda) e Iguape (direita). Refere-se ao corpo hídrico $(\downarrow)$ losango preto para os dois setores, ( $\mathbf{a})$ quadrado $(\mathrm{IC}),(\bullet)$ esfera (PA), (घ) quadrado (BI) e $(\bullet)$ esfera (MP). 


\section{Inverno 2009}

Observando os valores de temperatura no inverno 2009 (Tab. 6 e Fig. 14 ab) a faixa de variação de 18,78 a $21,84^{\circ} \mathrm{C}$ mostra queda sensível em relação ao período de verão e mostra que as águas do setor Sul estiveram ligeiramente mais aquecidas que o norte, uma vez que este último setor recebe maior influência de água continental. Os valores observados nos campo de $S$. alterniflora, em Cananéia (PA e IC) mostram a capacidade de retenção e captação de calor maior nestes campos em relação ao $\mathrm{CH}$ todo e também em relação ao observado $12 \mathrm{~h}$. O campo MP mostrou valor baixo de temperatura.

Em Cananéia, com o Valo Grande fechado, Braga (1995) observou variação de valores em estação fixa (1992) variando de $17,55^{\circ} \mathrm{C}$ a $18,45^{\circ} \mathrm{C}$, um pouco mais baixa do que o trabalho atual, mas mantendo uma faixa de inverno.

A salinidade (Tab.6 e Fig 14 c-d), que é um dos parâmetros que tem se mostrando mais marcante na diferenciação entre os setores norte e sul do sistema, mostrou valores maiores no setor sul, entre 21,72 e 32,28, em uma variação de maré de sizígia, com valores um pouco mais elevados que aqueles do período de verão e os campos de $S$. alternifora sendo que, PA mostrou valor igual ao $\mathrm{CH}$ e IC, valor superior, podendo refletir a contribuição da água intersticial. No caso de Iguape, os valores sempre muito baixos $(<3,5)$ continuam apontando a forte influência da entrada de água do Rio Ribeira de Iguape no sistema e nos campos, mais uma vez, se observa o maior valor no campo Bl, próximo a Barra de Icapara.

De acordo com Chiozzini et al. (2008) as águas do sistema de Cananéia, no período de inverno, apresentaram condições termohalinas bem características, com salinidade mais alta, variando entre 13,79 e 32,98 com média de 26,00 . Isto se deve ao baixo índice de chuvas do período.

Braga \& Chiozzini (2008) no inverno de 1992, na situação do canal fechado obteve a média de 28,82 e no inverno de 2005 , com o canal aberto a salinidade foi de 26,03. Observa-se assim uma diferença no setor sul nas condições do canal aberto e fechado. 
Barrera-Alba et al. (2007) registraram salinidade de 0,06 no ponto do Valo Grande, 3,71 no banco do Caranguejo, 11,5 na Ponte e 27,7 na Barra de Icapara para o inverno de 2001, já o inverno de 2005 os valores dos respectivos pontos foram 1,17; sem registro; 4,51 e 26,6 . 
Tabela 6. Dados hidrobioquímicos da campanha de agosto de 2009 (inverno), dos pontos dos setores norte e sul do complexo Estuarino-Lagunar Cananéia-Iguape e dos campos de S. alterniflora, sendo CH (corpo hídrico); PA (Ponta do Arrozal); MP (Mar Pequeno); BI (Barra do Icapara).

\begin{tabular}{|c|c|c|c|c|c|c|c|c|c|c|c|c|}
\hline \multicolumn{2}{|r|}{ Local } & Horário & $\begin{array}{c}\mathrm{T} \\
(\stackrel{\mathrm{o}}{\mathrm{C}})\end{array}$ & $\begin{array}{c}\text { Sal } \\
\text { (UPS) }\end{array}$ & $\begin{array}{c}\text { OD } \\
\left(m L L^{-1}\right)\end{array}$ & $\mathbf{p H}$ & $\begin{array}{c}\text { Silicato } \\
(\mu \mathrm{M})\end{array}$ & $\begin{array}{c}\text { Fosfato } \\
(\mu \mathrm{M})\end{array}$ & $\begin{array}{c}\text { MPS } \\
\left(\mathrm{mg} \mathrm{L}^{-1}\right)\end{array}$ & $\begin{array}{l}\% \text { MOS } \\
\text { no MPS }\end{array}$ & $\begin{array}{c}\mathrm{Cl}-a \\
\left(\mathrm{mg} \mathrm{m}^{-3}\right)\end{array}$ & $\begin{array}{c}\text { Feo } \\
\left(\mathrm{mg} \mathrm{m}^{-3}\right)\end{array}$ \\
\hline \multirow{10}{*}{ 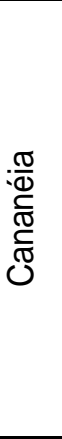 } & \multirow{7}{*}{$\begin{array}{c}\mathrm{CH} \\
19 / 08 / 2009\end{array}$} & 08:00 & 20.46 & 24.95 & 4.84 & 8.39 & 47.70 & 0.61 & 56.4 & 35.2 & 3.72 & 4.27 \\
\hline & & 10:00 & 20.80 & 22.19 & 4.76 & 8.23 & 63.25 & 0.65 & 44.0 & 35.4 & 2.05 & 0.12 \\
\hline & & $12: 00$ & 21.84 & 21.72 & 5.30 & 8.29 & 63.20 & 0.92 & 45.3 & 39.7 & 1.94 & 1.93 \\
\hline & & $14: 00$ & 20.79 & 29.92 & 5.14 & 8.42 & 23.64 & 0.45 & 73.7 & 32.2 & 4.15 & 21.97 \\
\hline & & $16: 00$ & 20.41 & 32.28 & 5.11 & 8.50 & 14.74 & 0.39 & 82.2 & 26.2 & 4.64 & 5.64 \\
\hline & & 18:00 & 20.51 & 29.74 & 5.11 & 8.47 & 24.96 & 0.52 & 70.7 & 36.5 & 2.88 & 3.03 \\
\hline & & 20:00 & 20.80 & 27.01 & 4.94 & 8.42 & 37.04 & 0.68 & 84.0 & 38.1 & 2.13 & 4.07 \\
\hline & \multicolumn{2}{|c|}{ Média } & 20.80 & 26.83 & 5.03 & 8.39 & 39.22 & 0.60 & 65.19 & 34.74 & 3.07 & 5.86 \\
\hline & $\overline{P A}$ & $12: 00$ & 23.20 & 21.72 & 5.12 & 8.42 & 69.26 & 0.92 & 77.71 & 31.25 & 7.44 & 8.78 \\
\hline & IC & 11:00 & 24.50 & 26.62 & 5.15 & 8.24 & 22.73 & 0.92 & 94.00 & 27.05 & 3.98 & 2.52 \\
\hline \multirow{10}{*}{$\begin{array}{l}\text { 음 } \\
\frac{\text { 믐 }}{\text { 으 }}\end{array}$} & & 07:00 & 20.23 & 2.98 & 5.38 & 7.45 & 136.85 & 2.15 & 25.1 & 27.4 & 4.70 & 6.36 \\
\hline & & 09:00 & 20.10 & 0.78 & 5.48 & 7.19 & 186.93 & 2.73 & 33.1 & 27.5 & 7.33 & 12.73 \\
\hline & & 11:00 & 18.86 & 0.36 & 5.63 & 7.02 & 149.26 & 3.13 & 15.1 & 32.4 & 7.50 & 13.01 \\
\hline & $\begin{array}{c}\text { CH } \\
22 / 08 / 2009\end{array}$ & 13:00 & 20.48 & 0.55 & 5.59 & 7.29 & 143.13 & 2.90 & 15.6 & 42.9 & 8.04 & 11.72 \\
\hline & $22 / 08 / 2009$ & $15: 00$ & 20.49 & 1.48 & 5.46 & 7.28 & 155.69 & 2.43 & 33.8 & 26.0 & 5.93 & 6.32 \\
\hline & & $17: 00$ & 18.78 & 5.17 & 5.42 & 7.66 & 200.36 & 2.00 & 23.8 & 39.3 & 2.74 & 4.00 \\
\hline & & 19:00 & 20.50 & 3.28 & 5.64 & 7.53 & 193.35 & 2.12 & 58.7 & 80.3 & 2.42 & 4.45 \\
\hline & \multicolumn{2}{|c|}{ Média } & 19.92 & 2.08 & 5.51 & 7.35 & 166.51 & 2.49 & 29.30 & 39.38 & 5.52 & 8.37 \\
\hline & $\mathrm{MP}$ & $12: 00$ & 17.90 & 1.01 & 5.17 & 7.16 & 150.63 & 1.78 & 91.00 & 24.18 & 13.95 & 17.32 \\
\hline & $\mathrm{BI}$ & $10: 00$ & 20.25 & 6.93 & 5.68 & 7.88 & 163.27 & 1.98 & 73.33 & 29.31 & 6.64 & 7.25 \\
\hline
\end{tabular}

Em negrito, período similar de coleta do corpo hídrico $(\mathrm{CH})$ com a coleta nos campos de Spartina alterniflora. 



종

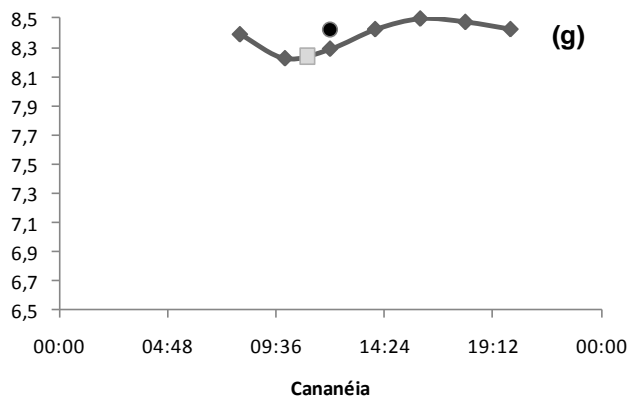

I

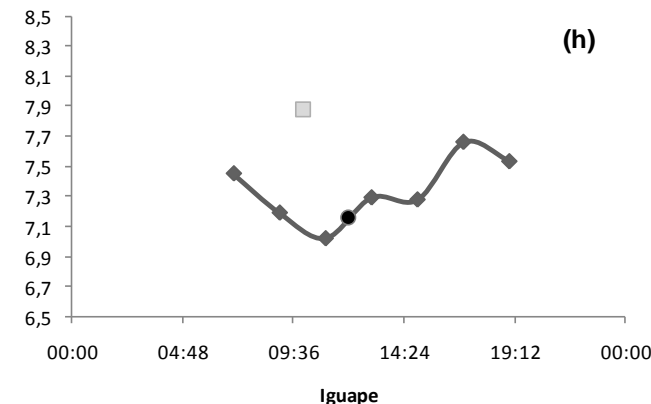

Figura 14. Variação temporal dos parâmetros físicos e químicos ao longo de um ciclo de maré no período do Inverno de 2009 nos dois setores, Cananéia (esquerda) e Iguape (direita). Refere-se ao corpo hídrico ( $\bullet$ losango preto para os dois setores,

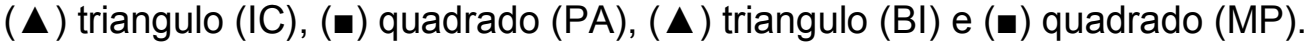


Os valores de oxigênio dissolvidos (Tab. 6 e Fig. 14 e-f) no inverno, nos dois setores (norte e sul) foram maiores que no verão, com muitos valores superiores a $5,0 \mathrm{~mL} \mathrm{~L}^{-1}$, incluindo os valores dos campos norte e sul. A baixa temperatura bem como os ventos que sopram neste período associados às frentes frias, auxiliam na oxigenação das águas.

Os valores de $\mathrm{pH}$ (Tab. 6 e Fig. $14 \mathrm{~g}$-h) variaram de 7,02 a 8,80, sendo os valores de Cananéia, mais uma vez os maiores. No inverno os valores sempre acima de 8,0, mesmo nos dois campos de $S$. alterniflora. No caso de Iguape, os valores foram menores, mas todos na faixa de 7,0, também nos campos da gramínea. Neste caso, os valores de $\mathrm{pH}$ refletem a maior salinidade e teor de oxigênio presente no período de inverno.

Mais uma vez, os valores de silicato se mostraram extremamente altos (Tab. 6 e Fig. 15 a-b), com destaque ao setor norte, onde os valores variaram de 130 uM a 200 uM, com altos valores também nos campos MP e BI, refletindo o grande aporte de silicato também no período de inverno. Embora as chuvas sejam reduzidas, a vazão do rio assegura o aporte deste nutriente ao sistema norte e também ao sul, cuja variação foi de 14,74 a 69,26 e, o maior valor foi observado em $\mathrm{PA}$, mas foi bem próximo de $\mathrm{CH}$.

Braga (1995) observou em Cananéia (estação fixa) valores de silicato no inverno entre 3,1 e 16,1 uM, com o Valo Grande fechado.

Braga \& Chiozzini (2008) em dois invernos de Cananéia, sob diferentes condições: o Valo Grande fechado (1992) e aberto (2005) registraram teores médios de silicato de $8,8 \mu \mathrm{M}$ e $13,4 \mu \mathrm{M}$, respectivamente.

Os valores de fosfatos (Tab. 6 e Fig. 15 c-d) mostraram de um modo geral, valores de fosfato mais altos no inverno, sobretudo em Iguape, onde os valores de $\mathrm{CH}$ estavam todos acima de 2. Os campos de $S$. alterniflora de Cananéia mostraram valores bem próximos ao horário de $\mathrm{CH}$ (12h) e no caso de Iguape, os valores de fosfato foram <2,0 o que pode estar associado à própria dinâmica do $\mathrm{P}$, a qual mostra qrande afinidade do $\mathrm{P}$ dissolvido por material pelítico, que está presente em grande quantidade no setor norte devido á interferência antrópica. 
Braga (1995) apresentou valores de fosfato em Cananéia, no inverno variando de 0,08 a 0,56 uM, valor na faixa do observado atualmente.

Em dois invernos de Cananéia, Braga \& Chiozzini (2008), sob diferentes condições do Valo Grande, fechado em 1992 e aberto em 2005, registraram teores médios de fosfato de $0,12 \mu \mathrm{M}$ e $0,87 \mu \mathrm{M}$, respectivamente. Mostrando assim, uma ligeira ascendência nos níveis do nutriente no sistema sul depois da reabertura do canal.

Quanto aos teores de material particulado em suspensão (Tab. 6 e Fig. 15 e-f), os valores diminuíram muito no período de inverno, muito provavelmente devido a menor entrada e transporte pela drenagem, que é maior no verão devido às chuvas. Curioso que em relação ao $\mathrm{CH}$, os valores de Cananéia mais uma vez, foram ligeiramente maiores que os de Iguape, a qualidade do material novamente deve ser lembrada. Já junto aos campos de $S$. alterniflora, os valores foram sempre altos, quer no sul como no norte.

Braga (1995) mostrou valores de material particulado em suspensão no inverno em Cananéia na faixa de 17,6 a $38,4 \mathrm{mg} \mathrm{L}^{-1}$.

Pisetta (2010) mostrou a maior concentração de MPS total durante as coletas no Mar de Cananéia que foi $15,2 \mathrm{mg} \mathrm{L}^{-1}$ (fundo) e a menor 3,4 $\mathrm{mg} \mathrm{L}^{-1}$ (fundo). Excetuando-se o maior valor encontrado junto ao fundo, pode-se admitir que as concentrações estiveram homogêneas na coluna de água durante o período amostral. Assim pode-se afirmar que nesse setor ocorre uma mistura homogênea do corpo hídrico, refletindo para as bordas do estuário.

A fração de matéria orgânica presente no MPS, no inverno foi bem menor que no verão, ficando abaixo de 50\% (Tabela 6 e Fig. 7 g-h) com exceção do $\mathrm{CH}$, às $19 \mathrm{~h}$ em Iguape, na maré vazante. Os campos de $S$. alterniflora refletiram os valores baixos do período e com valores mais baixos que o $\mathrm{CH}$ em Cananéia e Iguape.

De um modo geral, o período de inverno, além de ser de baixa produtividade é um momento onde a matéria orgânica está sendo transformada em inorgânica como mostram os valores de porcentagem de MO. 

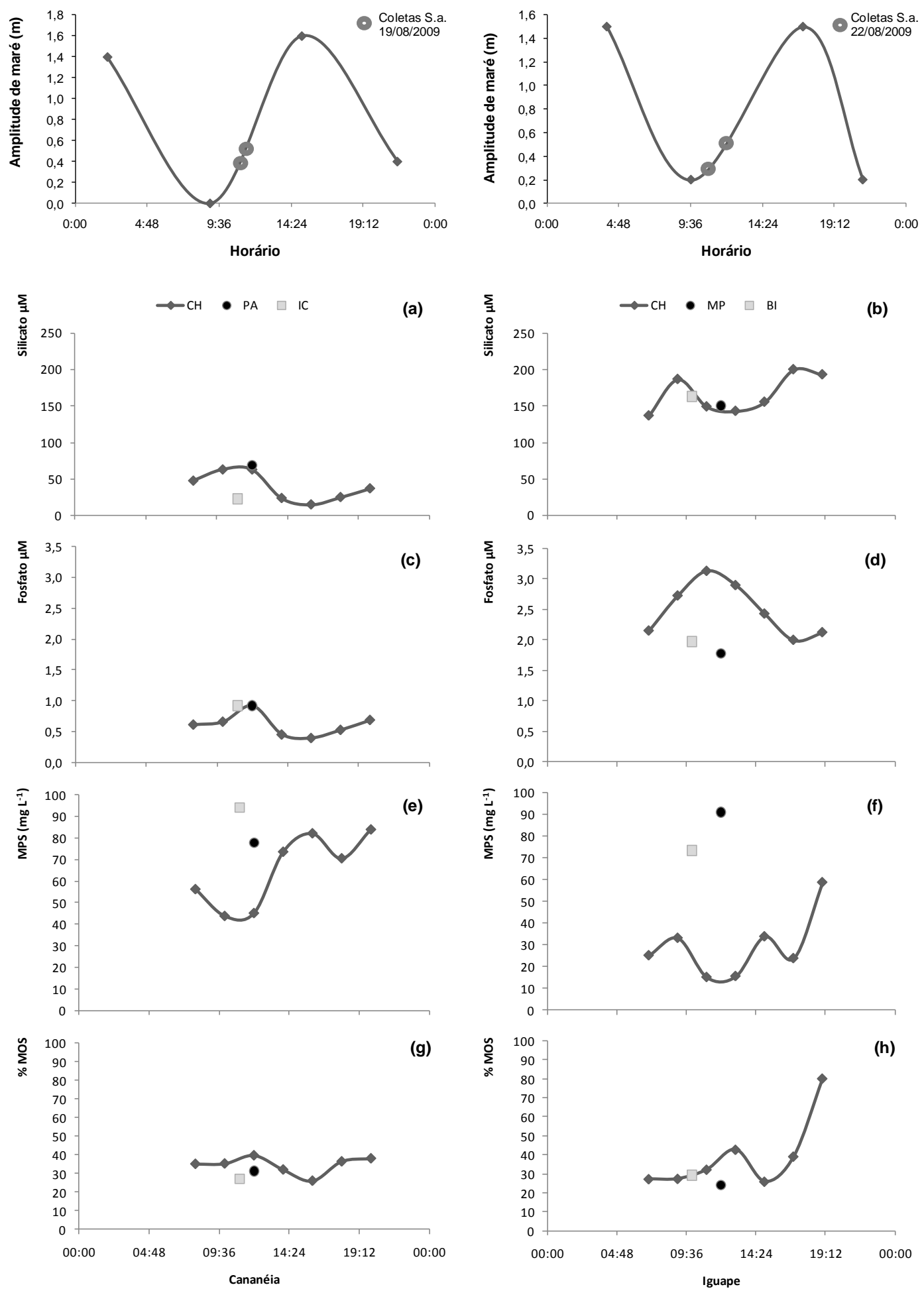

Figura 15. Variação temporal dos teores de silicato, fosfato, MPS e \%MOS ao longo de um ciclo de maré no período do inverno de 2009 em dois setores, Cananéia (esquerda) e Iguape (direita). Refere-se ao corpo hídrico ( $\bullet$ losango preto para os


(MP). 
Os valores de clorofila a (Tab. 6 e Fig 16 a-b) no inverno foram menores que os de verão, porém há uma surpresa em relação aos valores ligeiramente maiores em lguape, observados no período de enchente. Os valores junto aos campos de $S$. alterniflora em Iguape também se mostraram mais altos, no caso de MP o maior valor $\left(13,95 \mathrm{mg} \mathrm{m}^{-3}\right)$ foi observado. E no caso de Cananéia, isto foi observado em PA. Talvez as condições criadas nestes microcosmos podem ter auxiliado no processo de fotossíntese, uma vez que há disponibilidade de nutrientes.

Os valores médios de feopigmento (Tab. 6 e Fig.16 c-d) foram maiores que no verão, evidenciando os processos de decomposição que continuam a ocorrer no período que antecede a primavera.

Braga (1995) observou valores de clorofila a em estação fixa em Cananéia, no inverno de 1992 até $11,32 \mathrm{mg} \mathrm{m}^{-3}$.

De um modo geral, as diferenças nas características do corpo de água e campos de gramínea entre o inverno e verão são marcantes, mas é mantida a diferença entre os setores norte e sul nos dois períodos. Há também a evidencia de que no inverno, as atividades de produção primária são mantidas na água e que, os campos de $S$. alterniflora muitas vezes podem possibilitar a formação de microambientes favoráveis a alguns processos. 

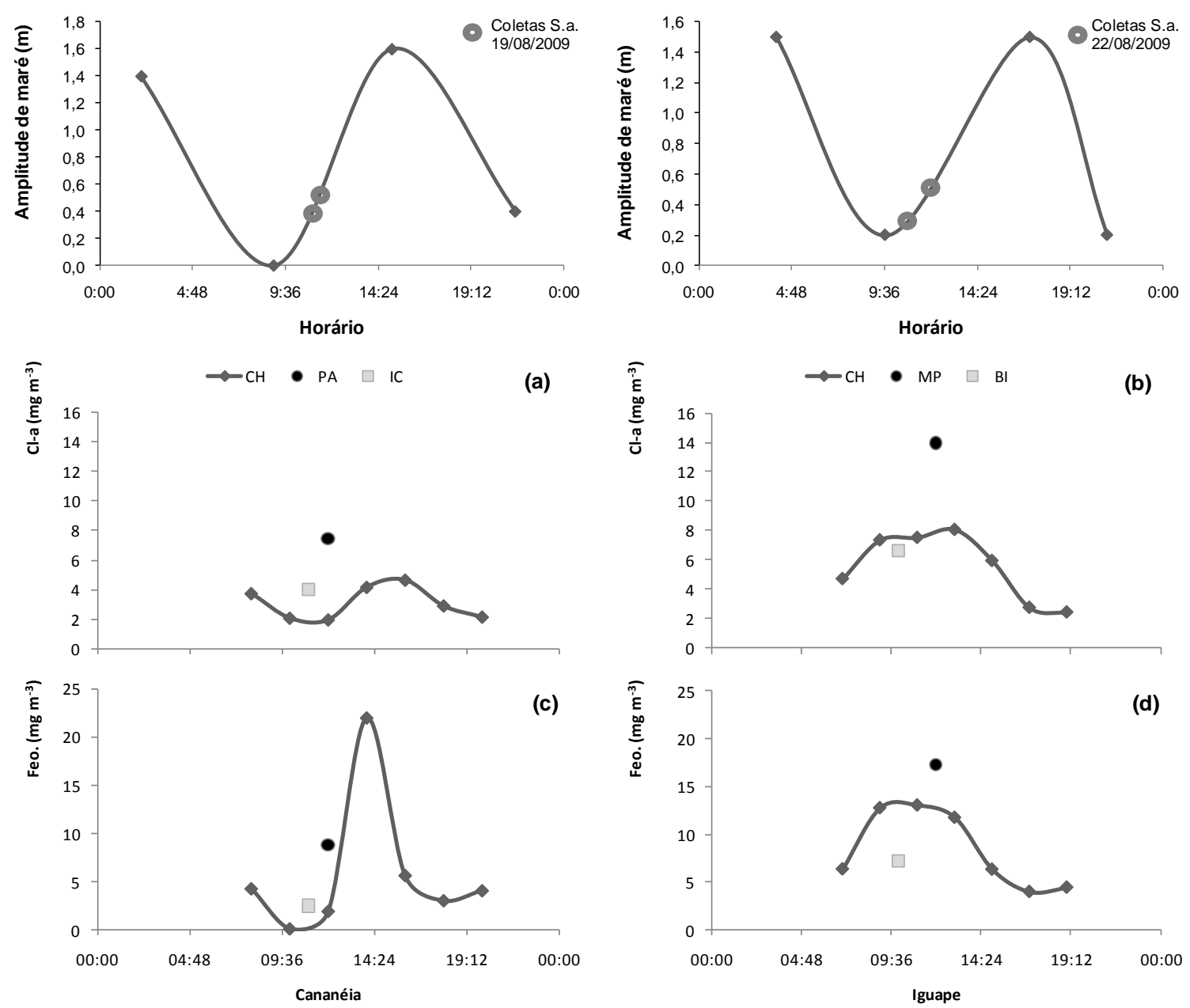

Figura 16. Variação temporal da clorofila a e feofitina ao longo de um ciclo de maré no período do inverno de 2009 em dois setores, Cananéia (esquerda) e Iguape (direita). Refere-se ao corpo hídrico $(\bullet)$ losango preto para os dois setores, (घ) quadrado $(\mathrm{IC}),(\bullet)$ esfera (PA), (ø) quadrado (BI) e $(\bullet)$ esfera (MP).

\section{Verão 2010}

Observando a tabela 7 e a figura 17 a-b nota-se que o período de amostragem mostrou águas mais frias que em 2009, com valores entre 25,20 e $26,85^{\circ} \mathrm{C}$ no $\mathrm{CH}$ e que os campos de $S$. alterniflora sul (PA e IC) apresentaram águas mais frias que $\mathrm{CH}$ no horário 9h, e também, em relação a todo período. Em Iguape, os valores de temperatura também foram menores.

No caso da salinidade (Tab. 7 e Fig.17 c-d) os valores gerais foram menores que aqueles observados em 2009, no mesmo período e campos de $S$. 
alterniflora PA e BI mostraram valores de salinidade maiores que os observados em $\mathrm{CH}$ em horários próximos à amostragem.

Os valores de oxigênio (Tab. 7 e Fig 17 e-f) estiveram na mesma faixa observada em 2009 e o pH (Fig. 17 g-h) mostrou valores mais alcalinos no setor sul, com o mesmo comportamento de 2009.

Os nutrientes silicato e fosfato (Tab. 7 e Fig. 18 a,b,c,d), mostraram a mesma variação observada em 2009, com destaque ao enriquecimento nos campos IC e MP.

O material particulado em suspensão (Tab. 7 e Fig. 18 e-f) mostrou valores bem menores que em 2009, mas manteve o valor relativamente alto em PA e BI. Já a matéria orgânica em suspensão (Tab. 7 Fig. $18 \mathrm{~g}$-h) mostrou valores em geral, bem menores que em 2009.

Vale a pena ressaltar que a amostragem de 2009 foi feita em fevereiro e a de 2010 foi feita em março, e que o metabolismo do sistema é diferente nestes dois momentos, o que está refletido nas temperaturas, salinidade, MPS e MOS, entre outros.

Os valores de clorofila $a$ e feopigmentos (Tab. 7 e Fig. 19 a,b,c,d) mostraram valores similares para $\mathrm{CH}$ em Cananéia àqueles do verão $2009 \mathrm{e}$, ligeiramente mais enriquecidos em Iguape. No caso dos campos de gramínea, PA mostra diminuição da clorofila e BI mantém valor próximo ao de 2009.

É natural que algumas diferenças inter-anuais ocorram, mostrando também a diferença de metabolismo dentro de um mesmo período considerado. De toda forma, os campos de $S$. alterniflora, muitas vezes mostram diferenças hidrogeoquímicas em relação ao corpo de água principal do sistema em seus dois setores. 
Tabela 7. Dados hidrobioquímicos da campanha de março de 2010 (verão), nos pontos dos setores norte e sul do complexo Estuarino-Lagunar Cananéia-Iguape e dos campos de S. alterniflora, sendo CH (corpo hídrico); PA (Ponta do Arrozal); MP (Mar pequeno); BI (Barra do Icapara).

\begin{tabular}{|c|c|c|c|c|c|c|c|c|c|c|c|c|}
\hline \multicolumn{2}{|r|}{ Local } & \multirow{2}{*}{$\begin{array}{c}\text { Horário } \\
\text { 07:00 }\end{array}$} & \multirow{2}{*}{$\begin{array}{c}\begin{array}{c}\mathbf{T} \\
\left({ }^{\circ} \mathbf{C}\right)\end{array} \\
25.33\end{array}$} & \multirow{2}{*}{$\begin{array}{c}\begin{array}{c}\text { Sal } \\
\text { (UPS) }\end{array} \\
27.34\end{array}$} & \multirow{2}{*}{$\begin{array}{c}\begin{array}{c}\text { OD } \\
\left(\mathrm{mL} \mathrm{L}^{-1}\right)\end{array} \\
4.55\end{array}$} & \multirow{2}{*}{$\begin{array}{c}\mathbf{p H} \\
8.40\end{array}$} & \multirow{2}{*}{$\begin{array}{c}\begin{array}{c}\text { Silicato } \\
(\mu \mathbf{M})\end{array} \\
27.15\end{array}$} & \multirow{2}{*}{$\begin{array}{c}\begin{array}{c}\text { Fosfato } \\
(\mu \mathrm{M})\end{array} \\
0.45\end{array}$} & \multirow{2}{*}{$\begin{array}{c}\begin{array}{c}\text { MPS } \\
\left(\mathbf{m g ~ L}^{-1}\right)\end{array} \\
51.37\end{array}$} & \multirow{2}{*}{$\begin{array}{c}\% \text { MOS } \\
\text { no MPS } \\
25.57\end{array}$} & \multirow{2}{*}{$\begin{array}{c}\begin{array}{c}\mathrm{Cl}-a \\
\left(\mathrm{mg} \mathrm{m}^{-3}\right)\end{array} \\
5.26\end{array}$} & \multirow{2}{*}{$\begin{array}{c}\begin{array}{c}\text { Feo } \\
\left(\mathrm{mg} \mathrm{m}^{-3}\right)\end{array} \\
8.01\end{array}$} \\
\hline & & & & & & & & & & & & \\
\hline \multirow{9}{*}{ 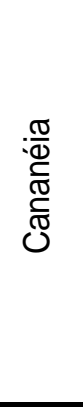 } & \multirow{6}{*}{$\begin{array}{c}\mathrm{CH} \\
17 / 03 / 2010\end{array}$} & 09:00 & 26.17 & 19.50 & 3.90 & 8.18 & 56.93 & 0.85 & 54.40 & 23.53 & 10.37 & 11.93 \\
\hline & & 11:00 & 26.39 & 16.08 & 3.89 & 8.12 & 72.64 & 0.97 & 42.20 & 26.54 & 11.78 & 10.77 \\
\hline & & $13: 00$ & 26.65 & 18.51 & 4.73 & 8.31 & 63.21 & 0.46 & 43.80 & 26.03 & 14.14 & 14.68 \\
\hline & & $15: 00$ & 26.53 & 25.93 & 4.96 & 8.49 & 34.88 & 0.34 & 51.60 & 29.07 & 10.50 & 6.56 \\
\hline & & $17: 00$ & 26.85 & 30.32 & 4.72 & 8.55 & 18.15 & 0.66 & 69.60 & 27.30 & 7.45 & 11.73 \\
\hline & & 19:00 & 25.20 & 23.37 & 4.92 & 8.39 & 47.35 & 0.64 & 42.40 & 29.72 & 5.20 & 3.95 \\
\hline & \multicolumn{2}{|c|}{ Média } & 26.16 & 23.01 & 4.52 & 8.35 & 45.76 & 0.62 & 50.77 & 26.82 & 9.24 & 9.66 \\
\hline & PA & 08:00 & 24.50 & 25.57 & 4.39 & 8.34 & 30.86 & 0.50 & 96.20 & 23.70 & 16.23 & 19.73 \\
\hline & IC & 09:00 & 24.00 & 19.84 & 3.81 & 8.23 & 54.76 & 0.84 & 59.00 & 25.08 & 11.32 & 10.71 \\
\hline \multirow{9}{*}{$\begin{array}{l}\frac{ષ}{ㅇ ㅡ ㅁ ~} \\
\frac{\text { 믐 }}{}\end{array}$} & \multirow{7}{*}{$\begin{array}{c}\mathrm{CH} \\
15 / 03 / 2010\end{array}$} & 08:00 & 25.14 & 0.03 & 4.28 & 6.58 & 195.90 & 1.77 & 43.60 & 12.84 & 3.91 & 7.25 \\
\hline & & 10:00 & 25.60 & 0.03 & 3.99 & 6.70 & 196.39 & 1.90 & 21.05 & 11.25 & 2.11 & 2.46 \\
\hline & & $12: 00$ & 26.22 & 0.03 & 4.58 & 6.71 & 215.34 & 1.99 & 18.95 & 18.06 & 2.81 & 2.25 \\
\hline & & $14: 00$ & 25.99 & 0.03 & 4.40 & 6.84 & 202.87 & 2.22 & 11.43 & 30.00 & 5.15 & 7.89 \\
\hline & & $16: 00$ & 26.27 & 0.29 & 4.67 & 6.99 & 192.41 & 1.86 & 19.43 & 14.71 & 2.87 & 3.31 \\
\hline & & 18:00 & 25.71 & 0.12 & 4.70 & 7.00 & 334.47 & 2.07 & 21.71 & 19.74 & 2.16 & 1.74 \\
\hline & & 20:00 & 25.75 & 0.03 & 3.95 & 6.86 & 354.41 & 2.00 & 51.14 & 12.29 & 4.76 & 8.19 \\
\hline & \multicolumn{2}{|c|}{ Média } & 25.81 & 0.08 & 4.37 & 6.81 & 241.68 & 1.97 & 26.76 & 16.98 & 3.39 & 4.73 \\
\hline & $\mathrm{BI}$ & 09:00 & 25.55 & 0.60 & 5.26 & 7.57 & 192.91 & 2.11 & 399.00 & 10.44 & 7.04 & 9.73 \\
\hline
\end{tabular}

Em negrito, período similar de coleta do corpo hídrico $(\mathrm{CH})$ com a coleta nos campos de Spartina alterniflora. 

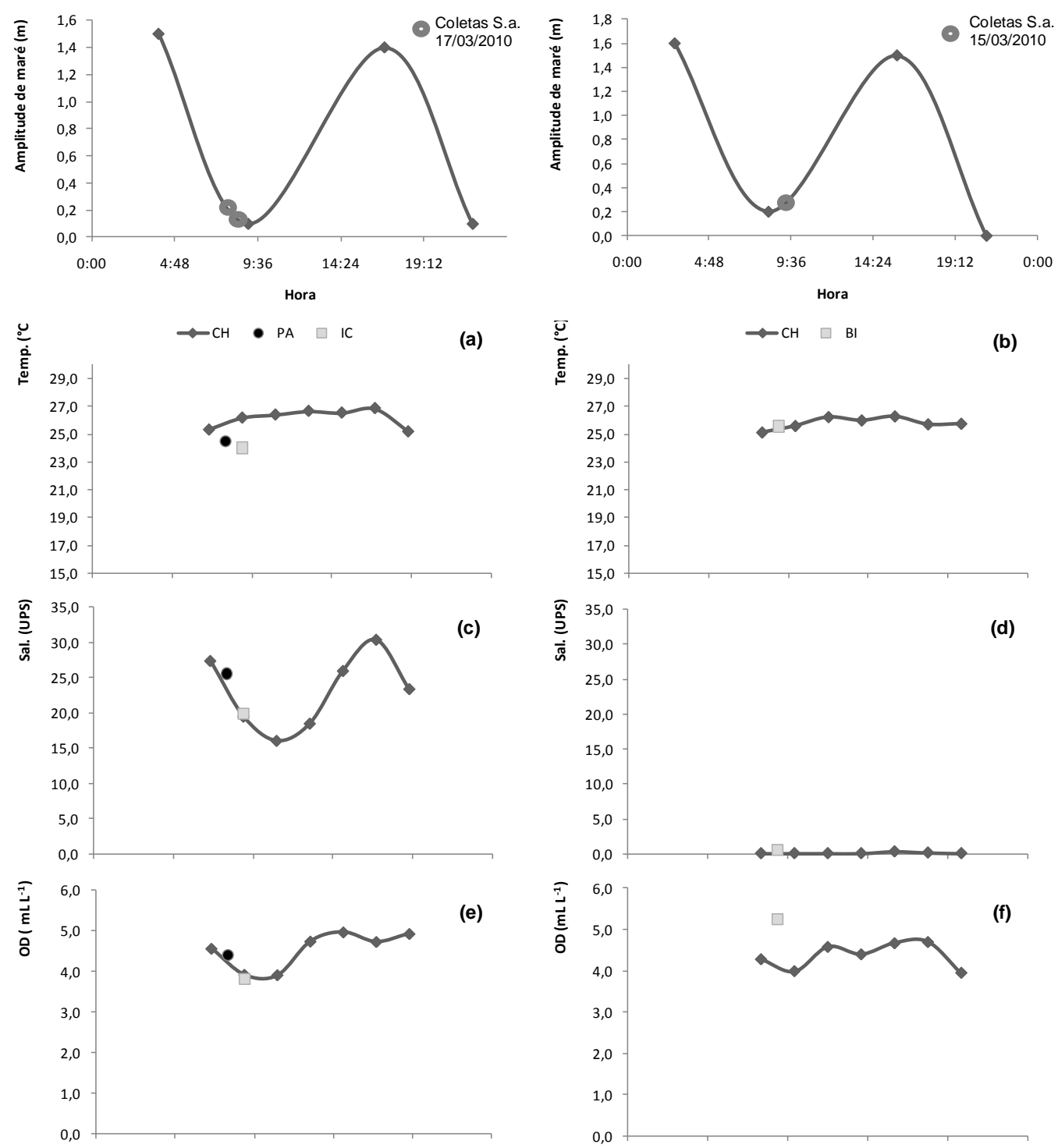

동

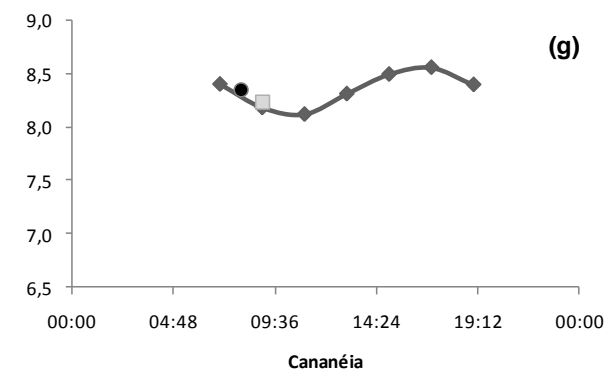

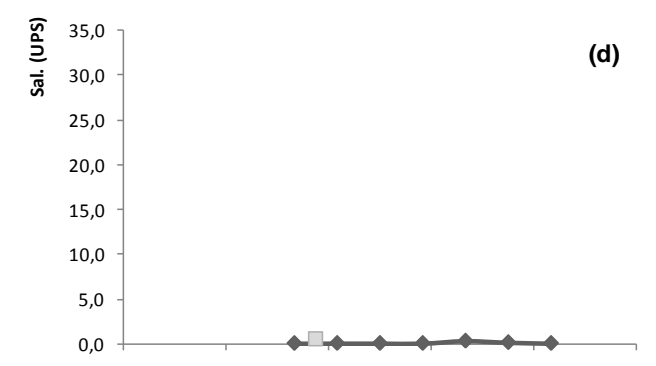



(d)

(f)

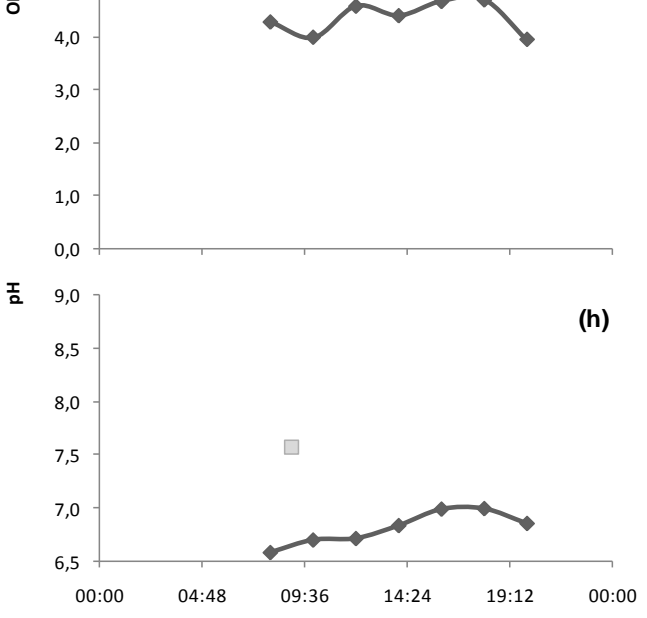

Iguape

Figura 17. Variação temporal dos parâmetros físicos e químicos ao longo de um ciclo de maré no período de Verão de 2010 nos dois setores, Cananéia (esquerda) e Iguape (direita). Refere-se ao corpo hídrico $(\diamond)$ losango preto para os dois setores, $(\boldsymbol{\Delta})$ triangulo (IC), (a) quadrado (PA) e ( $\mathbf{\Delta})$ triangulo $(\mathrm{BI})$. 

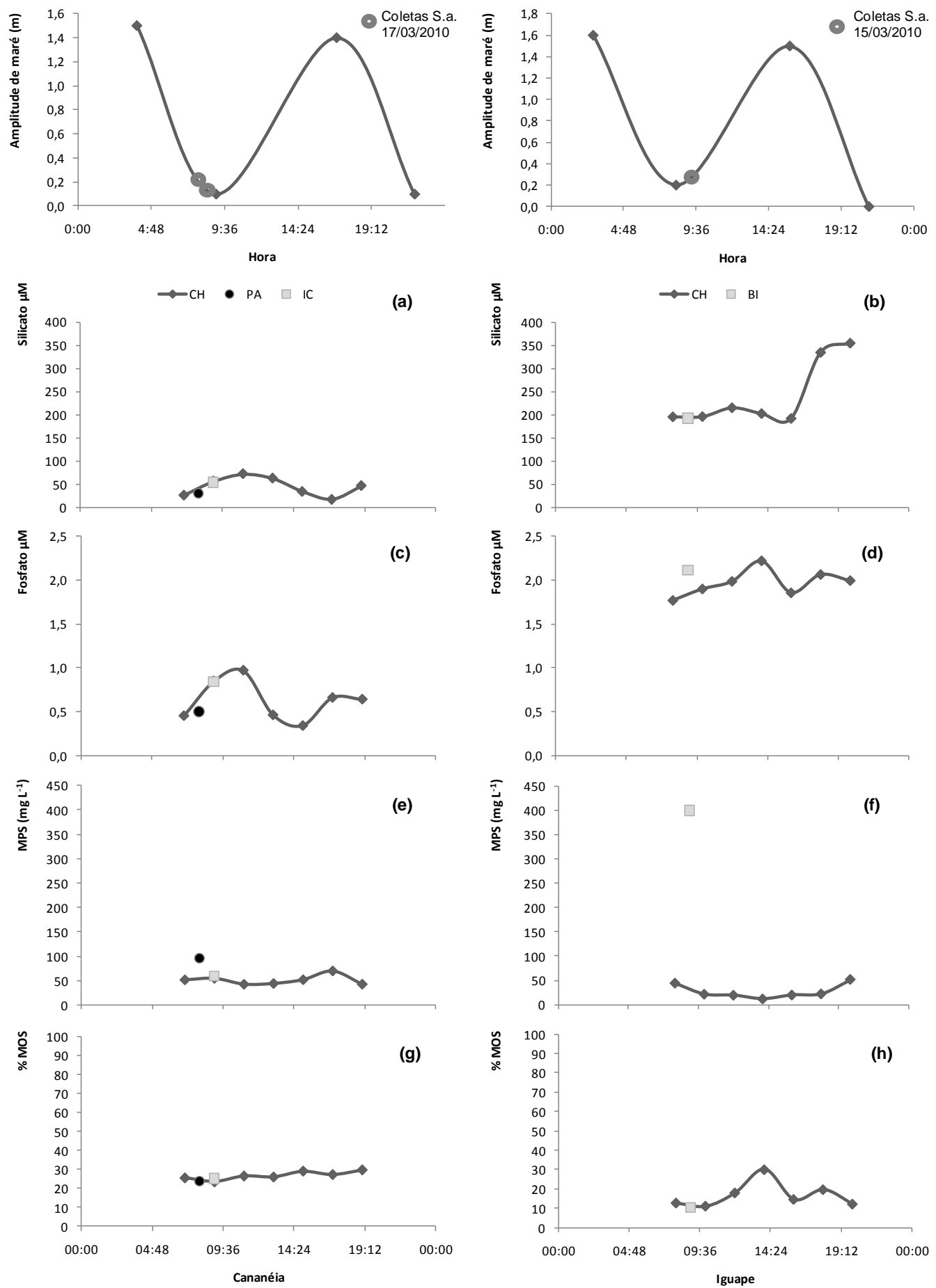

Figura 18. Variação temporal dos teores de silicato, fosfato, MPS e \%MOS ao longo de um ciclo de maré no período do verão de 2010 em dois setores, Cananéia (esquerda) e lguape (direita). Refere-se ao corpo hídrico ( $\downarrow$ ) losango preto para os dois setores, $(\mathbf{\square})$ quadrado $(\mathrm{IC}),(\bullet)$ esfera $(\mathrm{PA})$ e $(\mathbf{\bullet})$ quadrado $(\mathrm{BI})$. 

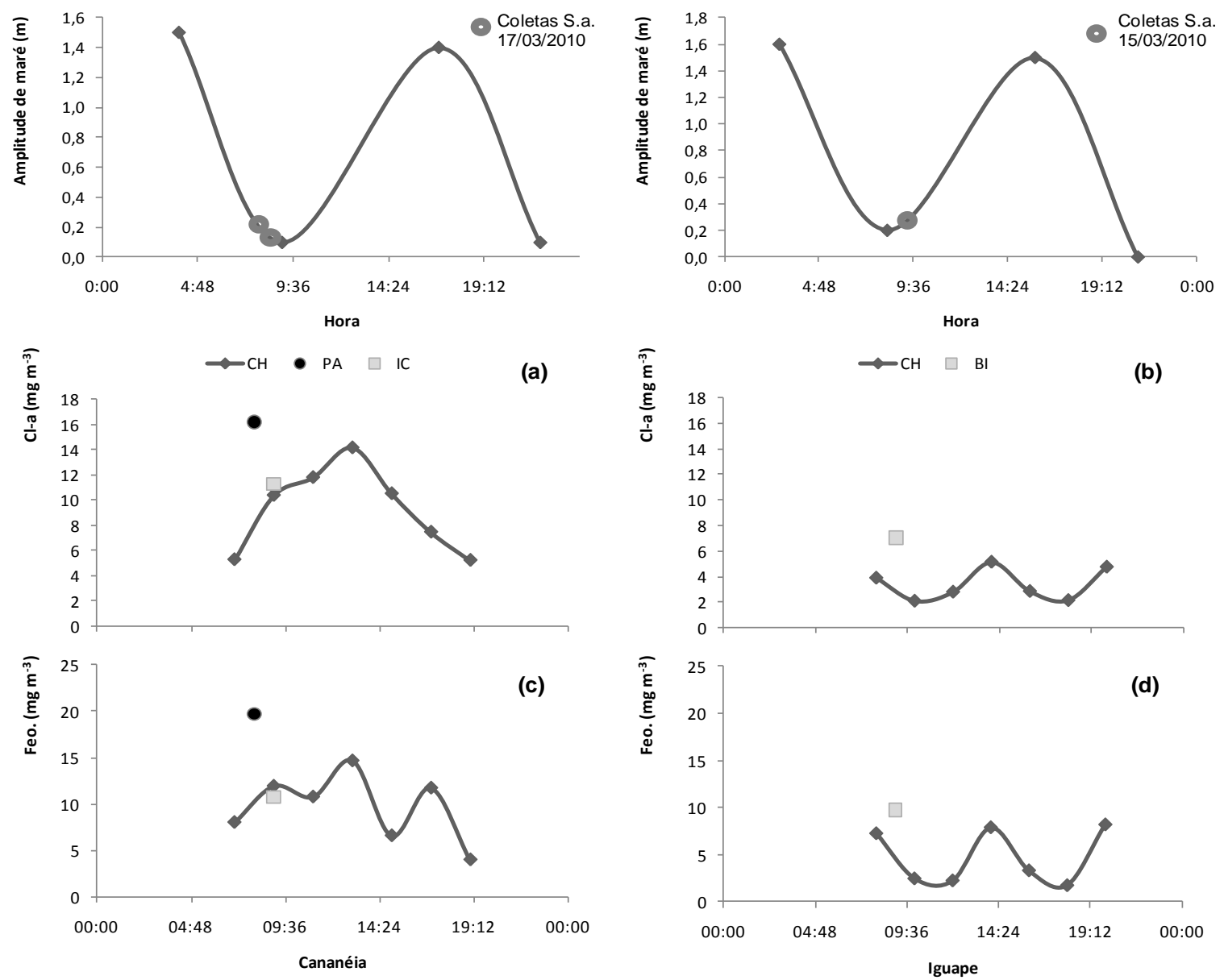

Figura 19. Variação temporal da clorofila a e feofitina ao longo de um ciclo de maré no período do verão de 2010 em dois setores, Cananéia (esquerda) e Iguape (direita). Refere-se ao corpo hídrico $(\downarrow)$ losango preto para os dois setores, ( $\mathbf{a})$ quadrado $(\mathrm{IC}),(\bullet)$ esfera (PA) e (घ) quadrado (BI). 


\section{Dados sedimentológicos}

Durante as amostragens de $S$. alterniflora, pelo menos três amostras de sedimento foram coletadas junto a cada quadrado. Os resultados da caracterização do sedimento superficial de cada campo de $S$. alteniflora constam na Tabela 8 sendo representados pelas informações de dois pontos de amostragem considerados mais representativos do sedimento de cada local. $\mathrm{Na}$ composição dos diagramas de Shepard (Figs 20, 22 e 23), as análises de mais de duas amostras de sedimentos foram consideradas, sendo divididas para compor cada período de amostragem. Alguns aspectos visuais dos campos amostrados são apresentados na Figura 21.

De acordo com Cintrón e Schaeffer-Novelli (1983), os solos dos manguezais possuem características altamente variáveis devido às suas diferentes origens. Seus sedimentos podem ser oriundos da intemperização de rochas intrusivas, vulcânicas ou sedimentares, ou ainda, constituírem-se de uma combinação destes tipos. Em geral, por serem ambientes de baixa energia, há predominância de frações finas (siltes e argilas).

O gênero Spartina spp possui uma característica que é sua utilização para estabilizar o ambiente costeiro, colonizando áreas instáveis como planícies de maré e diminuindo o impacto nas áreas que possam sofrer erosão.

\section{Verão 2009}

Os sedimentos do campo IC no verão de 2009 (Tabela 8) foram classificados segundo Folk \& Ward principalmente como silte grosso e areia fina, com os grãos pobremente e bem selecionados e, de assimetrias positivas. Os teores de MO mostraram valores de 17,6 e 1,2\% e os teores de carbonatos foram 1,5 e $0,3 \%$ respectivamente para cada classificação. 
Complementando o setor sul, o campo PA apresentou sedimentos mais homogêneos classificados como areia muito fina, com o grão bem e muito bem selecionado, de assimetria positiva e aproximadamente simétrica. Os teores de MO mostraram valores que atingiram $2 \%$ e os de carbonatos atingiram $0,5 \%$.

$\mathrm{Na}$ região norte, o sedimento do campo BI, em fevereiro de 2009 apresentou sedimentos classificados como silte grosso e areia fina, com os grãos muito pobremente e bem selecionados, de assimetria positiva. Os teores de MO atingiram 7,5 e os teores de carbonatos $3,9 \%$.

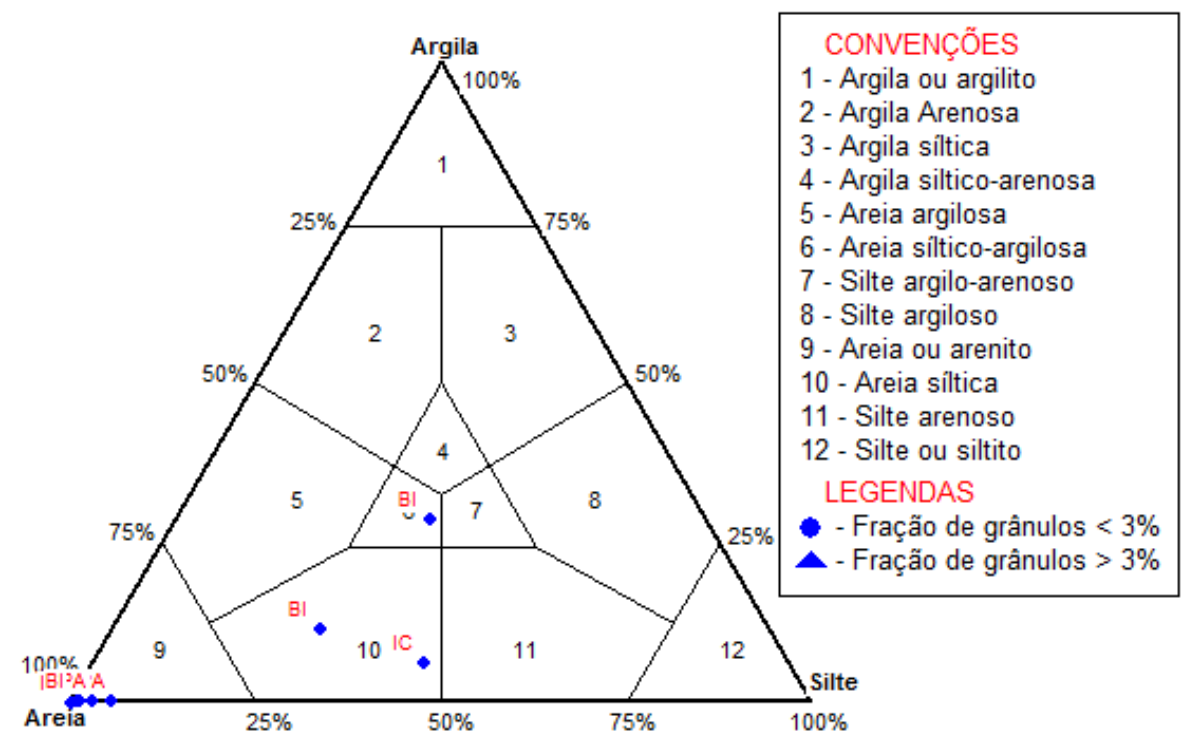

Figura 20. Classificação textural segundo Shepard (1954) para sedimentos dos campos de Spartina alterniflora em fevereiro de 2009.

Na campanha de fevereiro de 2009, o diagrama da Figura 20 apresenta a concentração das amostras do setor sul (Cananéia), próximas à aresta dominada por areia, exceto uma amostra do campo da IC que encontra-se classificada como areia síltica. Enquanto as amostras do campo BI se distribuem pelas convenções 6, 9 e 10 do diagrama.

De acordo com Adaime (1978), a classificação do sedimento da Ponta do Arrozal apresentou grande dominância da fração areia fina com teores de calcário entre 0,27 e 1,33 e de matéria orgânica entre 0,12 e 0,23\%. Esta classificação da 
composição sedimentar corrobora com aquela do presente estudo mostrando que o campo da PA pode ser uma área preservada, apesar de ocorrerem algumas variações sazonais em sua composição, formando ciclos de deposição, importação, erosão e exportação.

\section{Inverno 2009}

Os sedimentos do campo IC em agosto de 2009 (Tabela 8), seguindo a classificação de Shepard (1954), mantiveram sua composição como areia, permanecendo no diagrama bem próximo ao domínio da distribuição ocorrida no período anterior (verão 2009). Os teores de $\mathrm{MO}$ atingiram 2,5\% e de carbonatos foram $0,4 \%$.

O campo PA em agosto de 2009 apresentou sedimentos com ampla distribuição (Figura 22), havendo amostras com grande percentual de silte e argila, ficando amplamente distribuídas no diagrama. Nota-se assim, uma alteração da composição sedimentar nesse campo entre o período de verão e de inverno de 2009.

Segundo Adaime (1978), em experimento realizado em uma área desnudada de vegetal, verificou uma alteração da composição sedimentar do campo da PA em dois anos seguidos, passando de areia fina a areia fina lamosa e, os teores de calcário variaram de 6,34 a 9,36\% e os de MO de 10,2 a 16,08\%. 
Tabela 8. Dados da caracterização do sedimento superficial dos campos de $S$. alterniflora dos setores norte e sul do CELCI nos períodos de verão e inverno de 2009 e verão de 2010 .

\begin{tabular}{|c|c|c|c|c|c|c|c|c|c|c|c|c|c|c|c|}
\hline \multirow{2}{*}{ Periodo } & \multirow{2}{*}{ Local } & \multirow{2}{*}{ Campo } & \multirow{2}{*}{$\begin{array}{c}\text { Diâmetro } \\
\text { Médio }\end{array}$} & \multirow{2}{*}{$\begin{array}{l}\text { Classificação de } \\
\text { Shepard (1954) }\end{array}$} & \multicolumn{4}{|c|}{ Descrição e Parâmetros de Folk \& Ward } & \multirow{2}{*}{\multicolumn{2}{|c|}{ \% Seixos \% Grânulos }} & \multirow{2}{*}{ \% Areia } & \multirow[b]{2}{*}{$\%$ Silte } & \multirow{2}{*}{$\%$ Argila } & \multirow[b]{2}{*}{$\%$ MO } & \multirow[b]{2}{*}{$\% \mathrm{CaCO}_{3}$} \\
\hline & & & & & Classe & Seleção & Assimetria & Agudez & & & & & & & \\
\hline \multirow{5}{*}{$\begin{array}{l}\text { Verão } \\
2009\end{array}$} & \multirow{4}{*}{ Cananéia } & \multirow{2}{*}{ PA } & 3.00 & areia & areia muito fina & bem selecionado & positiva & leptocúrtica & 0 & 0 & 94.3 & 5.7 & 0.0 & 2.0 & 0.4 \\
\hline & & & 3.07 & areia & areia muito fina & muito bem selecionado & aproximadamente simétrica & leptocúrtica & 0 & 0 & 97.0 & 3.0 & 0.0 & 1.5 & 0.5 \\
\hline & & \multirow{2}{*}{ IC } & 4.79 & areia síltica & silte grosso & pobremente selecionado & muito positiva & leptocúrtica & 0 & 0 & 49.0 & 44.8 & 6.2 & 17.6 & 1.5 \\
\hline & & & 2.53 & areia & areia fina & bem selecionado & positiva & mesocúrtica & 0 & 0 & 99.7 & 0.3 & 0.0 & 1.2 & 0.3 \\
\hline & Iguape & $\mathrm{BI}$ & 2.52 & areia & areia fina & bem selecionado & positiva & mesocúrtica & 0 & 0 & 99.0 & 1.0 & 0.0 & 2.4 & 0.6 \\
\hline \multirow{6}{*}{$\begin{array}{l}\text { Inverno } \\
2009\end{array}$} & \multirow{4}{*}{ Cananéia } & \multirow[b]{4}{*}{ IC } & 3.95 & areia & Areia muito fina & Pobremente selecionado & Muito positiva & Muito leptocúrtica & 0 & 0 & 76.2 & 19.0 & 4.8 & 1.0 & 4.6 \\
\hline & & & 4.33 & areia sítica & silte grosso & pobremente selecionado & muito positiva & leptocúrtica & 0 & 0 & 56.2 & 32.1 & 11.7 & 13.2 & 0.9 \\
\hline & & & 2.63 & areia & areia fina & bem selecionado & positiva & mesocúrtica & 0 & 0 & 98.6 & 1.4 & 0.0 & 2.5 & 0.3 \\
\hline & & & 2.56 & areia & areia fina & bem selecionado & positiva & mesocúrtica & 0 & 0 & 99.5 & 0.5 & 0.0 & 1.7 & 0.4 \\
\hline & \multirow[t]{2}{*}{ Iguape } & \multirow[b]{2}{*}{$\mathrm{BI}$} & 4.35 & areia síltica & Silte grosso & Muito pobremente selecionado & Muito positiva & Platicúrtica & 0 & 0 & 62.8 & 23.8 & 13.4 & 3.2 & 7.1 \\
\hline & & & 3.19 & areia & Areia muito fina & Pobremente selecionado & Muito positiva & Extremamente leptocúrtica & 0 & 0 & 82.7 & 11.1 & 6.2 & 1.9 & 4.4 \\
\hline \multirow{6}{*}{$\begin{array}{c}\text { Verão } \\
2010\end{array}$} & \multirow{4}{*}{ Cananéia } & \multirow{2}{*}{ PA } & 3.66 & areia sítica & Areia muito fina & Pobremente selecionado & Muito positiva & Muito leptocúrtica & 0 & 0 & 72.5 & 23.8 & 3.7 & 6.6 & 1.9 \\
\hline & & & 3.85 & areia sítica & Areia muito fina & Pobremente selecionado & Muito positiva & Muito leptocúrtica & 0 & 0 & 76.6 & 18.7 & 4.7 & 4.0 & 0.5 \\
\hline & & \multirow{2}{*}{ IC } & 2.58 & areia & Areia fina & Bem selecionado & $\begin{array}{l}\text { Positiva } \\
\end{array}$ & Platicúrtica & 0 & 0 & 99.3 & 0.7 & 0.0 & 2.2 & 0.4 \\
\hline & & & 2.56 & areia & Areia fina & Moderadamente selecionado & Muito positiva & Leptocúrtica & 0 & 0 & 94.7 & 4.2 & 1.1 & 2.1 & 0.6 \\
\hline & \multirow{2}{*}{ Iguape } & \multirow{2}{*}{$\mathrm{BI}$} & 6.68 & Silte argiloso & Silte fino & Pobremente selecionado & Muito negativa & $\begin{array}{l}\text { Platicúrtica } \\
\end{array}$ & 0 & 0 & 12.8 & 51.8 & 35.4 & 3.9 & 3.9 \\
\hline & & & 2.36 & areia & Areia fina & Moderadamente selecionado & Muito positiva & Muito leptocúrtica & 0 & 0 & 94.9 & 4.1 & 1.0 & 2.0 & 1.3 \\
\hline
\end{tabular}


Figura 21. Aspectos macro-visuais da área dos campos de Spartina alterniflora, (a) campo PA, (b) campo IC e (c) campo BI em maré baixa com aspectos do sedimento. Fotos: Braga \& Stein. 


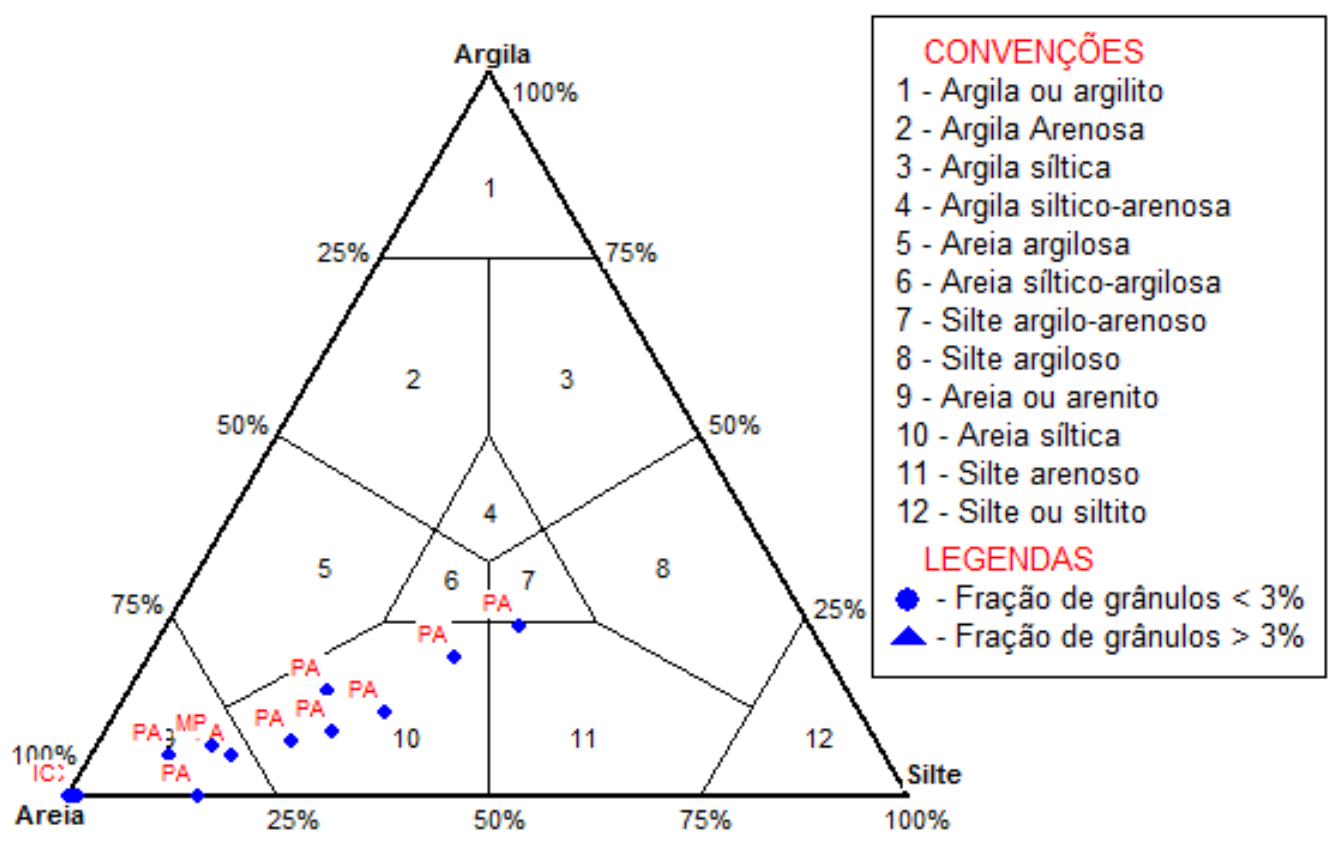

Figura 22. Classificação textural segundo Shepard (1954) para sedimentos dos campos de Spartina alterniflora em agosto de 2009.

Para os campos do setor norte em agosto de 2009 (Figura 22), houve a permanência da classificação sedimentar do campo BI de verão. Nesse período houve amostragem também no campo MP que foi classificado em areia muito fina com os grãos pobremente selecionados e assimetria muito positiva e os teores de $\mathrm{MO}$ e carbonatos foram 6 e 1,8\%, respectivamente.

\section{Verão 2010}

No verão de 2010 , os sedimentos amostrados nos campos do setor sul mantiveram sua composição sedimentar dentro da área distribuída no diagrama, nas convenções de areia e areia síltica e, os teores de $\mathrm{MO}$ e carbonatos também se mantiveram baixos.

No setor norte, em março de 2010, houve amostragem sedimentar somente no campo BI que, no diagrama de Shepard (1954) teve a classificação convencionada em silte argiloso (Figura 23). 


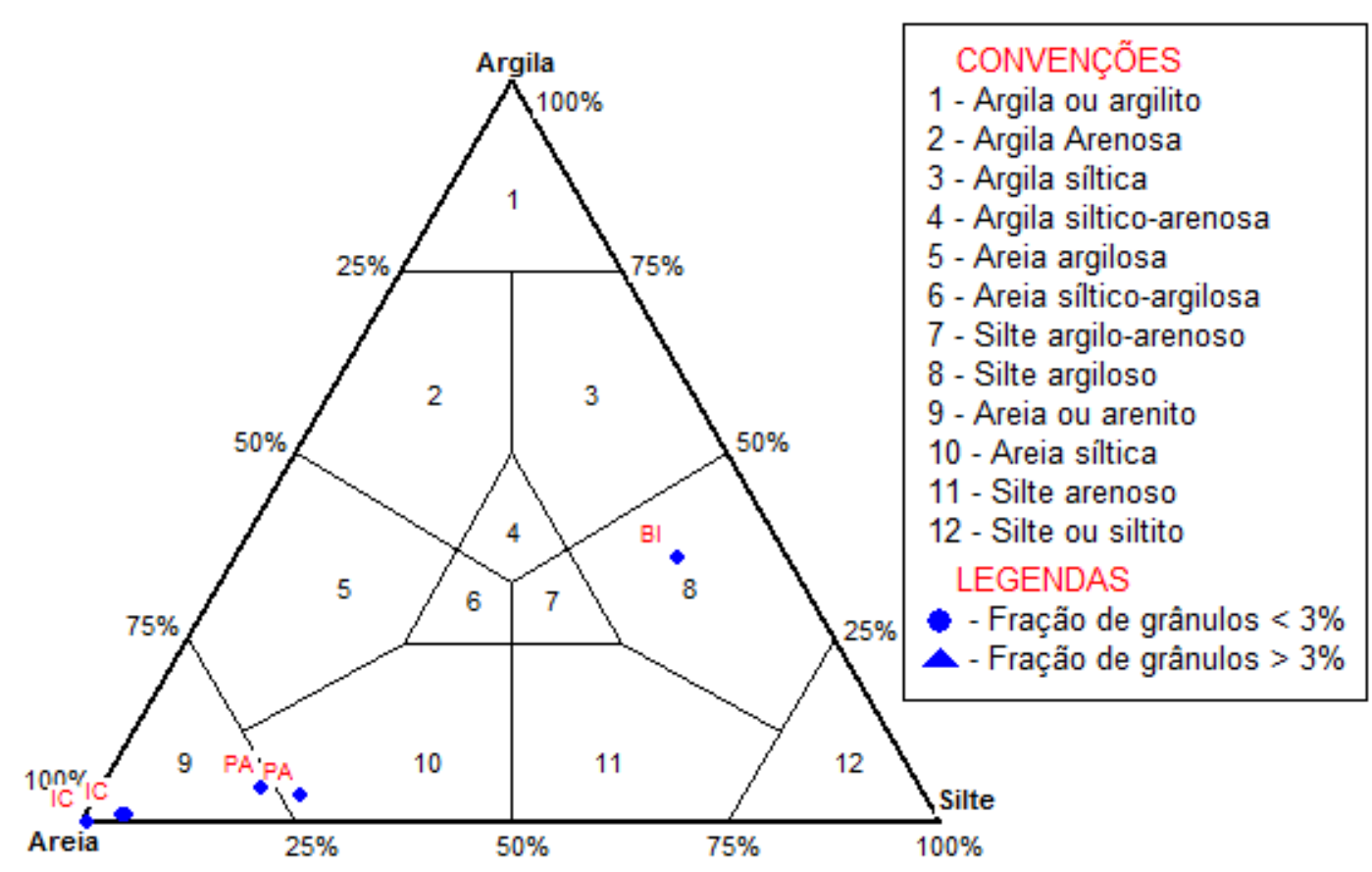

Figura 23. Classificação textural segundo Shepard (1954) para sedimentos dos campos de Spartina alterniflora em março de 2010.

Embora espécies de macrófitas dominantes em marismas ocorram ao longo de uma ampla faixa vertical e demonstrem um alto grau de sobreposição em sua distribuição, elas possuem preferências específicas em relação à topografia (Costa, 1998). No presente estudo, ocorre a dominância mono-específica da Spartina alterniflora nos bancos da franja do manguezal do $\mathrm{CELCI}$, formando assim uma estreita faixa do ecossistema marisma como ecótone. Este estudo compreende a composição sedimentar de cada banco e setor, embora a caracterização topográfica dos bancos não tenha sido realizada. Dessa forma, uma alternativa para a caracterização geomorfológica foi a descrição macro-visual dos bancos de Spartina.

Ao examinar os aspectos visuais da área dos campos da Spartina alterniflora, as imagens podem colaborar na caracterização dos sedimentos e campos da gramínea. O campo PA (Figura 21 a) tem uma extensa planície frontal lamosa de baixa declividade, em seguida o campo da gramínea entra num degrau superior a essa área sob um substrato com camada de mistura orgânica arenosa 
que sustenta o vegetal. A área em meio ao campo é de lama grossa e amplamente dominada por raízes e rizóides que podem chegar a profundidade de $40 \mathrm{~cm}$. O vegetal que cria essa estrutura radicular em meio ao sedimento é fortemente fixo nesse substrato, mesmo este sendo inconsistente na superfície.

A Figura 21b mostra a caracterização macro-visual do campo IC que possui uma zona frontal arenosa estreita, com declividade superior ao campo PA e está numa linha de inundação superior a este último, mais sujeito às variações diretas do $\mathrm{CH}$. Somado a isso, a presença da vegetação de terra firme (restinga ao fundo), mantêm os fluxos de drenagem terrestre, onde é possível ver a ramificação da drenagem em frente ao campo, permitindo o aporte de material terrestre. O perfil sedimentar mostrou uma camada superficial arenosa, seguida de uma areia-lamosa escura e aparentemente anóxida de onde espalham o sistema radicular da planta.

Nos campo BI (Figura 21 c) observa-se uma zona frontal arenosa estreita, que deixa o campo muito próximo à linha de água do corpo hídrico principal, a camada vegetal entra num segundo patamar que aparenta sofrer erosão devido à declividade e à brusca transição da zona arenosa para a camada vegetal. A $S$. alterniflora se sustenta numa camada humífera constituída de vegetal morto, moldada por lama e areia. Abaixo deste perfil tem uma camada de areia lamosa escura, provavelmente anóxida de onde diverge o sistema radicular profundo.

Ao correlacionar a caracterização sedimentar, os aspectos geomorfológicos macro-visuais, é importante observar a composição dos campos considerando os dois setores do CELCI quanto aos aspectos fisiográficos.

Em Iguape, o campo BI é estreito e pequeno, abrange uma pequena faixa da zona entre maré de frente para o corpo hídrico, a zona sedimentar de amortecimento é ausente, está numa área de considerável declividade sob forte erosão e o banco se sustenta sob um substrato detrítico formado por material morto da gramínea (Figura 24 a, b, c). O campo está situado próximo à Barra do Icapara, zona de altíssima hidrodinâmica que vem sofrendo processos de erosão 
em suas margens, se estendendo para dentro dos canais. Este processo erosivo dificultou o encontro da gramínea em todo setor norte.

No setor sul do CELCl encontra-se o campo PA, visualmente mais bem preservado, pois é um campo extenso que possui uma zona de amortecimento na faixa entre marés, com sedimento consolidado que promove a colonização e sustentação da gramínea (Figura 24 d, e, f).

Adaime (1978) mostrou que a fisionomia do banco de S.alterniflora. alterou-se bastante ao longo das épocas de coleta, principalmente quanto ao aspecto físico da gramínea e ao substrato onde se fixa. Observou-se durante o verão, gramíneas exuberantes e verdes, enquanto que no inverno eram amareladas e caídas. Quanto ao substrato, foi observado um aumento na fração arenosa. A deposição de areia fina foi maior nas proximidades das águas estuarinas e, à medida que esta distância aumentava, a deposição de areia fina tornou-se menor, aumentando porém, a fração de silte e argila no sedimento.

Foram verificadas, na lagoa dos Patos, algumas espécies dominantes (i.e., Spartina densiflora) atuando como importantes agentes geomorfológicos. Elas favorecem o soerguimento da superfície da marisma e são capazes de modificar os padrões de drenagem e fisiografia local (Figueroa et al., 1985). Isso ocorre porque as suas copas promovem a deposição de sedimento fino em suspensão na coluna de água, e suas densas redes de raízes reduzem a erosão do sedimento depositado, formando um microambiente de baixa hidrodinâmica. 


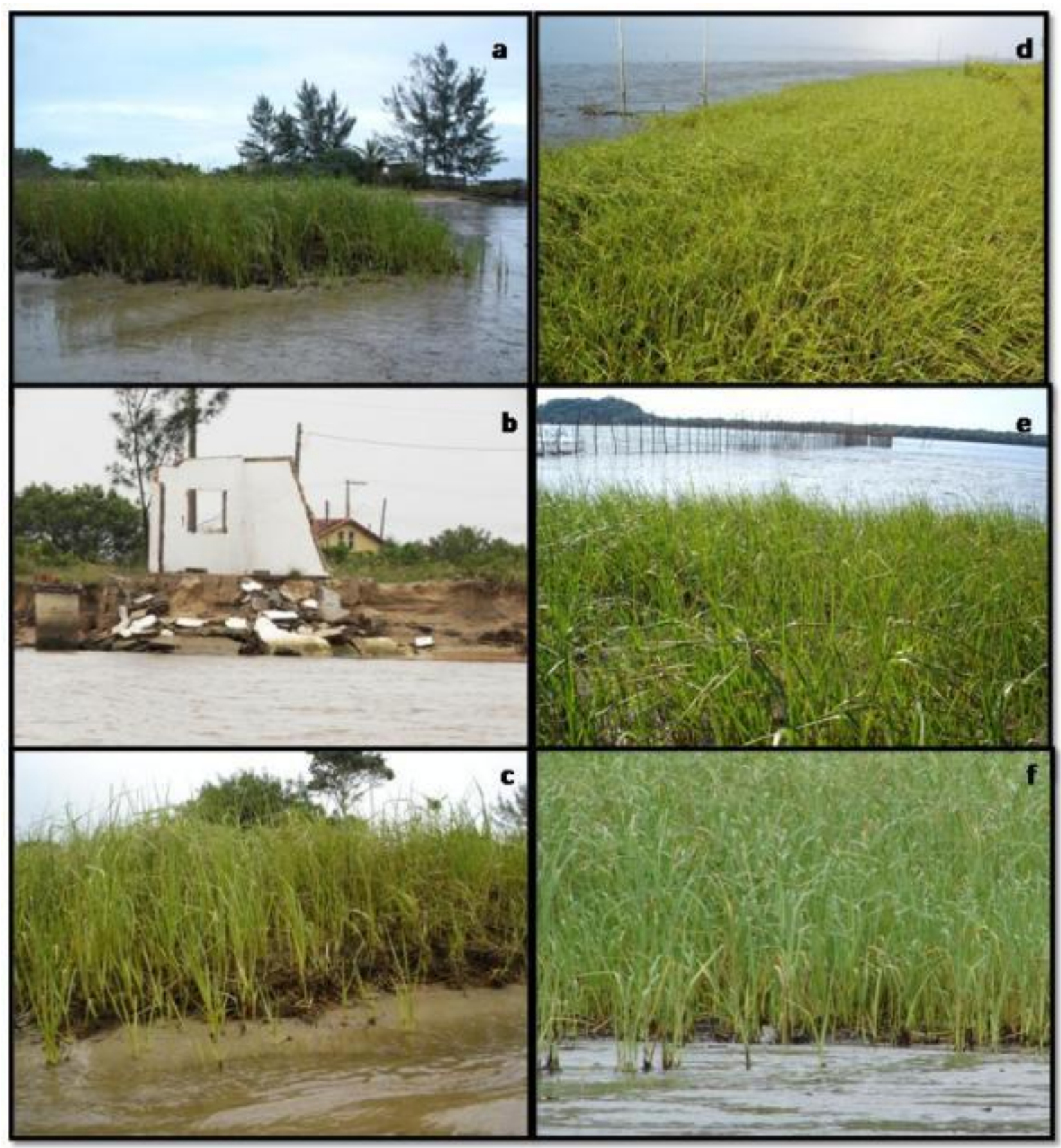

Figura 24. Aspectos macro-visuais dos bancos de Spartina alteniflora em Iguape (esquerda) e Cananéia (direita). Fotos: Braga \& Stein.

Em ecossistema de marisma há competição interespecífica de plantas halófitas pela área alagável, seja em período de colonização ou desenvolvimento da cobertura vegetal, no entanto a região que abrange o CELCI forma somente uma franja monoespecífica da espécie Spartina alterniflora. Em Cananéia, no setor sul do CELCI, os bancos da gramínea colonizam a linha de frente dos 
manguezais em extensas faixas, enquanto no setor norte, em lguape, os campos de Spartina estão em processo de erosão, havendo assim pequenas áreas ainda colonizadas pela macrófita. Conhecer a composição sedimentar, a fisiografia e a geomorfologia das áreas dominadas por Spartina é importante para caracterizar o tipo de ambiente preferencial do vegetal, uma vez que este é o principal colonizador da área de franja de manguezal na região de Cananéia.

Cunha-Lignon et al. (2009) destacaram o papel da S. alterniflora como potencial estabilizador inicial do manguezal, que por iniciar a colonização, reduzir a erosão e por sua expansão via crescimento vegetativo dos rizomas, ela aparece para preparar um substrato favorável a sucessão e formação do mangue. Neste estudo, os autores coletaram testemunhos em diversos segmentos do manguezal da região de Cananéia para conhecer a formação e sucessão deste ecossistema. Assim, encontraram na base de todos os testemunhos um padrão semelhante, sugerindo colonização similar por bosques de mangue, em toda sua extensão. Áreas em progradação que apresentam banco de sedimento exposto são colonizadas por S. alterniflora. Em seguida uma faixa de Laguncularia racemosa substitui a gramínea, com a progradação. Quando ocorre a maior consolidação do sedimento, outras espécies típicas de mangue passam a dominar o local formando um bosque maduro. No testemunho coletado na área colonizada pelo bosque maduro dominado por Avicennia shaueriana, há fragmentos de S. alterniflora próximos à base, confirmando o papel da gramínea como espécie pioneira. 


\section{Dados Biológicos}

\subsection{Caracterização dos Bancos de Spartina alterniflora}

De acordo com Schaeffer-Novelli et al. (1990) a área total entre-marés coberta por wetlands no sistema estuarino-lagunar de Cananéia seja de aproximadamente $90 \mathrm{~km}^{2}$ e, Spartina está presente somente numa estreita franja frontal protegendo habitats dominados por mangues. Essa gramínea foi mais abundante na porção norte do estuário quando o rio Ribeira de lguape descarregava através do canal artificial do Valo Grande. Spartina colonizava as franjas e bancos de areia construídos pela descarga de sedimentos do rio, mas depois do fechamento do canal, o manguezal começou a colonizar essas áreas.

Em fevereiro de 2009 (verão) foi realizada uma campanha piloto e vários parâmetros analisados foram testados e verificados quanto à melhor adequação das metodologias. Dessa forma foram amostrados quatro quadrados de $50 \times 50 \mathrm{~cm}$ neste período, 2 no sistema sul, distribuídos na Ponta do Arrozal e na llha Comprida. Na porção norte, foi amostrada a região do Mar Pequeno com um quadrante e, no setor extremo norte do sistema estuarino, na Barra de Icapara também com um quadrado. Estes quatro quadrados foram caracterizados biometricamente, apresentando resultados expressos na Tabela 9.

Nesse período, como foi uma campanha piloto, não se verificou a florescência dos indivíduos de cada quadrado amostrado, embora seja uma característica importante para relacionar seu período de reprodução e crescimento. 
Tabela 9. Medidas biométricas de $S$. alterniflora obtidas em indivíduos coletados em quadrados, no período do Verão de 2009, nas regiões de Cananéia e Iguape.

\begin{tabular}{|c|c|c|c|c|c|c|c|}
\hline \multirow{2}{*}{$\begin{array}{c}\text { Setor } \\
\text { Região } \\
\end{array}$} & \multirow{2}{*}{ Localização } & \multirow{2}{*}{ Quadrados } & \multirow{2}{*}{ \% Florescência } & \multirow{2}{*}{ Densidade } & \multicolumn{3}{|c|}{ Comprimento $(\mathrm{cm})$} \\
\hline & & & & & Média & Max & Min \\
\hline \multirow{3}{*}{ Cananéia } & PA & 1 & \multirow{4}{*}{ Não verficada } & 111 & 63 & 91 & 15 \\
\hline & IC & 1 & & 81 & 75 & 96 & 48 \\
\hline & MP & 1 & & 37 & 41 & 63 & 23 \\
\hline Iguape & $\mathrm{BI}$ & 1 & & 128 & 38 & 65 & 17 \\
\hline
\end{tabular}

A densidade encontrada no campo PA (Tabela 9), no verão de 2009 foi a mais alta de Cananéia e, de um modo geral, as alturas médias e máximas foram bem superiores àquelas dos indivíduos de Iguape.

Compartimentando os setores norte (Iguape) e sul (Cananéia), a diferença de altura mostrou que os campos de Cananéia são mais desenvolvidos. A densidade geralmente teve uma correlação negativa com a altura média de cada campo, ou seja, quando a densidade é menor, observa-se uma estatura maior das gramíneas.

Em agosto de 2009, houve aumento da quantidade de quadrados amostrados, com o total de 12, sendo 8 em Cananéia (4 na llha de Cananéia e 4 na Ilha Comprida), 2 no Mar Pequeno e 2 na Barra de Icapara. Os resultados biométricos dos quadrados amostrados podem ser visualizados na Tabela 10.

Nesse inverno (Tab. 10), a composição biométrica dos exemplares dos quadrantes amostrados foi diferente daquele observado no Verão de 2009, houve redução do comprimento médio dos campos do setor sul, enquanto que no setor norte, ocorreu o oposto. A florescência foi verificada e não houve ocorrência em nenhum exemplar coletado. A ausência de florescência corrobora com estudos que analisaram os períodos de crescimento e reprodução da Spartina, e segundo Adaime (1978) que estudou o campo da gramínea na Ponta do Arrozal, o inverno foi considerado como a época em que se obtém menor produção de $S$. alterniflora, uma vez que ocorre o decréscimo da quantidade de material vivo, sendo esta aumentada na primavera, quando se inicia a estação de crescimento, alcançandose o máximo de produção durante o verão. 
A produção anual de Spartina por metro quadrado está correlacionada com a altura que as plantas atingem na maturidade, sugerindo assim que a produção de Spartina possa ser realizada meramente pela determinação da distribuição de freqüência de sua altura no outono, porém Adaime (1978) encontrou, durante toda a época de coleta, grande número de plantas novas, provavelmente oriundas da reprodução vegetativa de seus rizomas. De certa forma, a medição de altura é válida como uma forma indireta de avaliar a produção da gramínea, visto que durante todo o ano (Adaime, op. cit.) observa-se a ocorrência de brotos nos campos. Dessa forma, no presente trabalho foi realizada a medição do comprimento dos indivíduos como forma indireta de avaliar a produção vegetal.

Tabela 10. Medidas biométricas de $S$. alterniflora obtidas em indivíduos coletados em quadrados (Q) no período de Inverno de 2009 nas regiões de Cananéia e Iguape.

\begin{tabular}{|c|c|c|c|c|c|c|c|}
\hline \multirow{2}{*}{$\begin{array}{l}\text { Setor } \\
\text { Região }\end{array}$} & \multirow[t]{2}{*}{ Localização } & \multirow[t]{2}{*}{ Amostra } & \multirow[t]{2}{*}{ \%Florescência } & \multirow[t]{2}{*}{ Densidade } & \multicolumn{3}{|c|}{ Comprimento $(\mathrm{cm})$} \\
\hline & & & & & Média & Max & Min \\
\hline \multirow{10}{*}{$\begin{array}{c}\text { Sul } \\
\text { (Cananéia) }\end{array}$} & \multirow{4}{*}{$\begin{array}{c}\text { (PA) Ponta } \\
\text { do } \\
\text { Arrozal }\end{array}$} & QA-1 & 0 & 67 & 43 & 76 & 9 \\
\hline & & QA-2 & 0 & 78 & 44 & 73 & 11 \\
\hline & & QA-3 & 0 & 61 & 40 & 67 & 12 \\
\hline & & QA-4 & 0 & 49 & 48 & 64 & 25 \\
\hline & \multicolumn{2}{|c|}{ Média do campo } & - & 64 & 44 & - & - \\
\hline & \multirow{4}{*}{$\begin{array}{l}\text { (IC) Ilha } \\
\text { Comprida }\end{array}$} & QC-1 & 0 & 32 & 47 & 91 & 13 \\
\hline & & QC-2 & 0 & 39 & 52 & 92 & 14 \\
\hline & & QC-3 & 0 & 67 & 27 & 38 & 12 \\
\hline & & QC-4 & 0 & 74 & 29 & 43 & 9 \\
\hline & \multicolumn{2}{|c|}{ Média do campo } & - & 53 & 38 & - & - \\
\hline \multirow{6}{*}{$\begin{array}{l}\text { Norte } \\
\text { (lguape) }\end{array}$} & (MP) Mar & QP-1 & 0 & 64 & 44 & 89 & 7 \\
\hline & Pequeno & QP-2 & 0 & 40 & 45 & 102 & 7 \\
\hline & \multicolumn{2}{|c|}{ Média do campo } & - & 52 & 44 & - & - \\
\hline & \multirow{2}{*}{$\begin{array}{l}\text { (BI) Barra } \\
\text { Icapara }\end{array}$} & Ql-1 & 0 & 113 & 54 & 83 & 22 \\
\hline & & QI-2 & 0 & 49 & 36 & 62 & 10 \\
\hline & \multicolumn{2}{|c|}{ Média do campo } & - & 81 & 45 & - & - \\
\hline
\end{tabular}

A variação entre o verão e o inverno de 2009 mostrou que houve redução da densidade e do comprimento médio dos campos, exceto para a região de Iguape, onde houve aumento do comprimento médio. Essa diferença de 
densidade e de biometria infere a mudança sazonal de produção de Spartina nos dois setores. No período quente e úmido do verão ocorreu a maior densidade e maior média de altura, sendo assim registrou a maior produção e, no inverno frio e seco ocorreu a menor densidade e altura média, enfim, a menor produção.

No verão de 2010 (Tabela 11) foi realizado o total de 11 quadrados de amostragem, sendo 8 em Cananéia (4 na Ponta do Arrozal e 4 na llha Comprida), e 3 em Iguape, na Barra do Icapara. O campo do Mar Pequeno, no dia de coleta, não apresentou condições adequadas à caracterização do local, pois o banco apresentava erosão e uma ínfima faixa de Spartina identificada, estava submersa.

Tabela 11. Medidas biométricas $S$. alterniflora obtidas em indivíduos coletados em quadrados, no período de Verão de 2010 nas regiões de Cananéia e Iguape.

\begin{tabular}{|c|c|c|c|c|c|c|c|}
\hline \multirow{2}{*}{$\begin{array}{c}\text { Setor } \\
\text { Região }\end{array}$} & \multirow[t]{2}{*}{ Localização } & \multirow[t]{2}{*}{ Amostra } & \multirow{2}{*}{ \% Florescência } & \multirow{2}{*}{ Densidade } & \multicolumn{3}{|c|}{ Comprimento (cm) } \\
\hline & & & & & Média & $\operatorname{Max}$ & Min \\
\hline \multirow{10}{*}{$\begin{array}{c}\text { Sul } \\
\text { (Cananéia) }\end{array}$} & \multirow{4}{*}{ PA } & QA-1 & 0 & 153 & 53 & 71 & 10 \\
\hline & & QA-2 & 8 & 122 & 72 & 101 & 34 \\
\hline & & QA-3 & 0 & 139 & 48 & 82 & 9 \\
\hline & & QA-4 & 12 & 69 & 50 & 89 & 19 \\
\hline & Média do campo & & - & 121 & 56 & - & - \\
\hline & & QC-1 & 32 & 35 & 70 & 103 & 25 \\
\hline & \multirow[t]{3}{*}{ IC } & QC-2 & 24 & 32 & 90 & 144 & 11 \\
\hline & & QC-3 & 23 & 56 & 57 & 96 & 16 \\
\hline & & QC-4 & 49 & 124 & 60 & 94 & 16 \\
\hline & Média do campo & & - & 62 & 69 & - & - \\
\hline \multirow{4}{*}{$\begin{array}{c}\text { Norte } \\
\text { (Iguape) }\end{array}$} & \multirow{3}{*}{$\mathrm{BI}$} & QI-1 & 0 & 124 & 81 & 141 & 32 \\
\hline & & QI-2 & 52 & 73 & 60 & 81 & 16 \\
\hline & & QI-3 & 15 & 88 & 58 & 102 & 11 \\
\hline & Média do campo & & - & 95 & 66 & - & - \\
\hline
\end{tabular}

O campo PA, no verão 2010, apresentou indivíduos com a menor média de altura, porém os quadrados amostrados tiveram elevada densidade e a florescência ocorreu em dois quadrados amostrados. Já no campo IC registrou-se florescência em todos os 4 quadrados amostrados, a média de altura foi $69 \mathrm{~cm}$ e a altura máxima registrada em todos os períodos e campos ocorreu no campo da Ilha Comprida nesse verão, um individuo atingiu o comprimento máximo de 144 $\mathrm{cm}$. 
Considerando que a $S$. alterniflora apresenta diversidade morfométrica, sendo conhecidas três formas: anã, média e alta, na área PA, Adaime (1978) encontrou apenas um tipo de S. alterniflora, cuja altura máxima foi de $130 \mathrm{~cm}$. Pelas estimativas obtidas para o "standing-crop" do material vivo, o máximo valor do "standing-crop", $816 \pm 187 \mathrm{~g}$ de peso seco/m² ocorreu em março e, em julho ocorreu o mínimo valor do "standing-crop", ou seja, $166 \pm 33 \mathrm{~g}$ de peso seco $/ \mathrm{m}^{2}$. Também na Ponta do Arrozal, Flynn et al. (1996) ao estudarem a macrofauna bêntica associada à gramínea, encontraram duas formas da estatura da Spartina, a forma baixa e a alta.

De acordo com Gross (1986), nos estuários da América do Norte, duas ou mais formas de Spartina podem ser distinguidas. Plantas de estatura alta crescem em áreas mais expostas como grandes enseadas e canais estuarinos, enquanto plantas de estatura menor crescem em áreas mais abrigadas. Entretanto, não é incomum encontrar plantas de $20-30 \mathrm{~cm}$ de altura crescendo próximas de plantas de 1,5-2,0 metros de altura.

No presente estudo, nota-se a ocorrência da $S$. alterniflora em diversas alturas nos campos amostrados, por exemplo, em março de 2010 no campo PA foi registrada a menor altura de $9 \mathrm{~cm}$, enquanto a maior foi de $101 \mathrm{~cm}$. Com essa elevada diferença de estatura, pode-se inferir que tanto no setor sul quanto no norte e entre um período sazonal de verão e inverno, ocorrem as 3 formas da Spartina.

A variação sazonal dos bancos de Spartina é evidenciada na

Figura 25 onde se encontra a distribuição de freqüências simples dos tamanhos da gramínea amostradas nos meses de fevereiro de 2009, agosto de 2009 e março de 2010. 



Figura 25: Distribuição de freqüência simples da estatura da Spartina alterniflora dos campos PA (I), IC (II), MP (III) e BI(IV), ao longo dos períodos, verão de 2009 (a), inverno de 2009 (b) e verão de 2010 (c). 


\section{O campo PA (}

Figura 25-I a; b; c) apresentou na primeira campanha, a distribuição de freqüência classes modais representativas de 70 e $80 \mathrm{~cm}$, perfazendo $58 \%$ dos indivíduos analisados. A ocorrência de alturas é ampla, podendo chamar de distribuição platicúrtica e, se estende da classe $20 \mathrm{~cm}$ até $100 \mathrm{~cm}$. Em agosto de 2009, período de inverno, as classes modais de alturas representativas reduzem de estatura, compõem estas classes espécimes de 50 e $60 \mathrm{~cm}$ totalizando $52 \%$ dos indivíduos do campo. A abrangência das classes encurta-se, havendo a distribuição de plântulas entre 10 e $80 \mathrm{~cm}$, considerando assim, uma distribuição mesocúrtica. Já no segundo verão, março de 2010, as classes de tamanho representativas do campo voltam a crescer, as classes de tamanhos de maior freqüência ocorrem na altura de 60 e $70 \mathrm{~cm}$ compreendendo $47 \%$ dos indivíduos do campo da Ponta do Arrozal. A ocorrência de alturas em março de 2010 fica entre 10 e $110 \mathrm{~cm}$, aumentando novamente a abrangência de estaturas, ocorrendo assim uma distribuição altamente platicúrtica. O campo registra assim, plântulas de baixa estatura e indivíduos altos ao mesmo tempo. Verifica-se nesses histogramas, a variação sazonal das classes de alturas representativas do campo PA que, nos verões apresentam concentração de indivíduos de maior estatura, enquanto que no inverno ocorre uma queda do tamanho das classes de indivíduos altos. A variação de estatura das plantas é correspondente aos períodos de desenvolvimento e reprodução da Spartina.

Adaime (1978) no campo da Ponta do Arrozal em Cananéia realizou experimento desnudando uma área vegetada para saber sua recomposição ao longo do tempo. O período monitorando foi de janeiro a novembro e o mês de março registrou o aumento da altura média das plantas de 32 para $45,5 \mathrm{~cm}$, ou seja, um desenvolvimento de $13,5 \mathrm{~cm}$ em dois meses.

O campo da llha Comprida (

Figura 25-II: a; b; c), em fevereiro de 2009, concentra sua estatura nas classes de tamanho 70,80 e $90 \mathrm{~cm}$, acumulando $78 \%$ dos indivíduos do campo. A distribuição ocorre entre 50 e $100 \mathrm{~cm}$, forma assim uma curta faixa de ocorrência 
de tamanhos da gramínea, caracterizando a distribuição como leptocúrtica. No período do inverno, agosto de 2009, as classes modais representativas reduzem de estatura e as alturas mais freqüentes estão entre 30 e $40 \mathrm{~cm}$, totalizando $55 \%$ dos indivíduos do campo e a faixa de ocorrência de tamanho está entre 10 e 100 $\mathrm{cm}$. Enquanto no verão de 2010, o mês de março registrou aumento das estaturas mais freqüentes, a distribuição das classes mais representativas foi de 60, 70 e 90 $\mathrm{cm}$ totalizando $55 \%$ dos indivíduos do campo da IC. Nesse campo, a alteração das classes de alturas representativas entre os períodos observados, também mostra que nos dois verões encontram-se indivíduos de maior estatura.

No setor norte, o campo do Mar Pequeno (

Figura 25-III: a; b; c) registrou no verão de 2009, a concentração de $52 \%$ dos seus indivíduos na classe de tamanho $50 \mathrm{~cm}$ e a distribuição esteve entre 30 e $70 \mathrm{~cm}$. Enquanto no inverno de 2009, o mês de agosto registrou uma ampla distribuição entre 10 e $90 \mathrm{~cm}$, e não houve a concentração de plantas numa determinada altura representativa, porem a classe de maior freqüência continua na estatura de $50 \mathrm{~cm}$.

No setor norte, a distribuição de freqüências do campo da Barra do Icapara (

Figura 25-IV: a; b; c) para o mês de fevereiro de 2009 apresentou uma distribuição concentrada das alturas das plantas, as classes mais representativas estiveram na estatura de 30,40 e $50 \mathrm{~cm}$, perfazendo $82 \%$ dos indivíduos do campo e esta distribuição de freqüências simples pode ser considerada leptocúrtica. A faixa de concentração de alturas significativas desse campo juntamente com o campo MP foi inferior aos demais campos, no verão de 2009. Em agosto, período do inverno de 2009, o campo registrou $41 \%$ dos indivíduos nas classes de tamanho 30 e $40 \mathrm{~cm}$, porém nesse período, a distribuição foi ampla entre as alturas 10 e $110 \mathrm{~cm}$. Enquanto que no verão de 2010, a amplitude de comprimento dos indivíduos continuou aumentando, sendo registradas alturas entre 20 e $150 \mathrm{~cm}$, entretanto houve aumento da classe de tamanho mais representativa, passou de $40 \mathrm{~cm}$ no inverno para $70 \mathrm{~cm}$ no verão. 
De um modo geral, os histogramas apresentados possuem um padrão semelhante de distribuição de freqüências de comprimentos para os campos da $S$. alterniflora. Encontram-se grandes concentrações de indivíduos em elevadas estaturas no primeiro verão, havendo o decaimento da altura no inverno de 2009, e novamente no verão (2010) ocorre a presença de elevadas alturas das plantas.

Os ciclos de crescimento sazonal das espécies dominantes das marismas do estuário, com metabolismo de assimilação de Carbono C4 (Spartina alterniflora e Spartina densiflora), estão relacionados com diferentes temperaturas ótimas do ar. A S. maritimus cresce rapidamente do início da primavera (temperaturas $<15^{\circ} \mathrm{C}$ ) até o seu pico de biomassa aérea viva no início do verão, sendo os picos de biomassa aérea morta e total observados no final do verão (Costa 1998a).

Em contraste, somente sob temperaturas maiores do que $20^{\circ} \mathrm{C}$, observadas no final da primavera, S. alterniflora (Cunha 1994) e S. densiflora (Silva et al. 1993) crescem rapidamente de forma vegetativa, em número e tamanho de folhas e hastes, e acumulam biomassa sobre a marisma. Os picos de biomassa morta e total de $S$. alterniflora e $S$. densiflora ocorrem, respectivamente, no início do outono e durante o período de outono e inverno. 


\subsection{Dados Multielementares em Spartina alterniflora}

As concentrações dos elementos obtidos pela Análise de Ativação Neutrônica (AAN) encontram-se dispostos na Tabela 12. Os elementos potássio, cálcio, ferro, zinco e cromo foram analisados quanto às diferenças entre os setores do Complexo Estuarino-Lagunar de Cananéia-Iguape, quanto à sazonalidade e quanto às diferenças da área vegetal da Spartina alterniflora, a parte aérea (caule e folha) e a parte subterrânea (raiz e rizóides).

Por definição, os nutrientes minerais têm funções específicas e essenciais no metabolismo da planta. Dependendo da quantidade requerida de um dado nutriente, o elemento pode ser classificado, como macronutriente ou micronutriente (Malavolta, 2006). Outra classificação, baseada nas propriedades fisicoquímicas, divide os nutrientes em metal (potássio, cálcio, magnésio, ferro, zinco, cobre, molibdênio e níquel) e não metais (nitrogênio, enxofre, potássio, boro, cloro). Segundo Prado (2009), as duas classificações são inadequadas uma vez que cada nutriente mineral pode realizar uma variedade de funções, algumas destas funções são pouco correlacionadas, com a quantidade requerida ou com propriedades fisicoquímicas. Um nutriente mineral pode funcionar como um constituinte de uma estrutura orgânica, como um ativador de reações enzimáticas, ou como transportador de cargas e osmorregulador. 
Tabela 12: Concentração dos elementos químicos encontradas nas partes aérea e subterrânea da $S$. alterniflora nas regiões de Cananéia e Iguape nos períodos de verão e inverno de 2009 e verão de 2010.

\begin{tabular}{|c|c|c|c|c|c|c|c|c|c|c|c|c|c|}
\hline Área Vegetal & Setor & Campo & Período & $\mathrm{K}\left(\mathrm{mg} \mathrm{kg}^{-1}\right)$ & sK & $\mathrm{Ca}\left(\mathrm{mg} \mathrm{kg}^{-1}\right)$ & $\mathrm{sCa}$ & $\mathrm{Fe}\left(\mathrm{mg} \mathrm{kg}^{-1}\right)$ & sFe & $\mathrm{Zn}\left(\mathrm{mg} \mathrm{kg}^{-1}\right)$ & sZn & $\mathrm{Cr}\left(\mathrm{ug} \mathrm{kg}{ }^{-1}\right)$ & $\mathrm{sCr}$ \\
\hline \multirow{10}{*}{ 产 } & \multirow{5}{*}{$\begin{array}{c}\text { Sul } \\
\text { (Cananéia) }\end{array}$} & \multirow{3}{*}{ PA } & Verão 2009 & 7092.0 & 400.0 & 1304.0 & 61.0 & 91.3 & 3.0 & 16.7 & 0.2 & - & - \\
\hline & & & Inverno 2009 & 12275.6 & 660.3 & 1887.9 & 64.1 & 178.6 & 2.8 & 18.5 & 0.1 & 689.7 & 22.1 \\
\hline & & & Verão 2010 & 14853.7 & 487.1 & 2002.8 & 88.7 & 355.8 & 2.7 & 20.0 & 0.1 & 1662.9 & 30.2 \\
\hline & & \multirow{2}{*}{ IC } & Inverno 2009 & 9630.1 & 428.6 & 1519.0 & 60.7 & 286.3 & 2.3 & 14.3 & 0.1 & 661.9 & 20.4 \\
\hline & & & Verão 2010 & 12458.3 & 540.4 & 1890.8 & 81.5 & 206.5 & 1.9 & 15.8 & 0.1 & 694.0 & 25.9 \\
\hline & \multirow{5}{*}{$\begin{array}{c}\text { Norte } \\
\text { (lguape) }\end{array}$} & \multirow{2}{*}{ MP } & Verão 2009 & 1738.0 & 639.0 & 1443.0 & 73.0 & 404.5 & 5.8 & 19.9 & 0.3 & - & - \\
\hline & & & Inverno 2009 & 20572.0 & 769.2 & 1718.0 & 92.4 & 671.2 & 4.5 & 18.5 & 0.1 & 1215.3 & 25.8 \\
\hline & & \multirow{3}{*}{$\mathrm{BI}$} & Verão 2009 & 10415.3 & 824.0 & 1188.3 & 73.0 & 181.5 & 1.9 & 10.8 & 0.1 & 349.8 & 17.2 \\
\hline & & & Inverno 2009 & 11921.0 & 595.1 & 1550.4 & 72.2 & 287.8 & 2.3 & 18.0 & 0.1 & 959.9 & 22.0 \\
\hline & & & Verão 2010 & 13875.8 & 281.4 & 1669.8 & 99.2 & 579.2 & 3.9 & 20.0 & 0.1 & 964.3 & 23.6 \\
\hline \multirow{7}{*}{$\begin{array}{l}\frac{\bar{J}}{J} \\
.00 \\
\frac{0}{0} \\
\tilde{\pi}\end{array}$} & \multirow{5}{*}{$\begin{array}{c}\text { Sul } \\
\text { (Cananéia) }\end{array}$} & \multirow{3}{*}{ PA } & Verão 2009 & - & - & 2485.0 & 88.0 & 2823.0 & 25.0 & 40.7 & 0.4 & 3019.0 & 48.0 \\
\hline & & & Inverno 2009 & 2535.1 & 307.3 & 3131.6 & 86.2 & 4771.6 & 25.0 & 45.5 & 0.3 & 8890.9 & 29.0 \\
\hline & & & Verão 2010 & 5529.2 & 240.6 & 2626.5 & 116.1 & 2222.7 & 13.1 & 42.8 & 0.2 & 4048.0 & 44.1 \\
\hline & & \multirow{2}{*}{ IC } & Inverno 2009 & 4192.6 & 190.6 & 3136.2 & 92.7 & 6200.5 & 41.5 & 36.7 & 0.3 & 2818.0 & 57.5 \\
\hline & & & Verão 2010 & 8800.0 & 539.0 & 2821.7 & 105.9 & 3298.7 & 19.7 & 20.5 & 0.2 & 1951.9 & 39.6 \\
\hline & \multirow{2}{*}{$\begin{array}{c}\text { Norte } \\
\text { (lguape) }\end{array}$} & MP & Verão 2009 & - & - & 2229.0 & 128.0 & 24029.0 & 193.0 & 23.9 & 0.4 & 2475.0 & 67.0 \\
\hline & & $\mathrm{BI}$ & Verão 2010 & 3610.8 & 232.0 & 1982.7 & 119.4 & 15912.0 & 86.0 & 40.3 & 0.3 & 2469.4 & 53.1 \\
\hline
\end{tabular}

${ }^{*} \mathrm{~S}$ = incerteza da concetração de $\mathrm{X}$ 
As principais funções dos nutrientes minerais tais como, nitrogênio, enxofre e fósforo que servem como constituintes de proteínas e ácidos nucléicos, outros nutrientes minerais, tais como magnésio e os micronutrientes (exceto cloro), podem funcionar como constituintes de estruturas orgânicas, predominantemente envolvidos na função catalítica de enzimas. O potássio e presumivelmente o cloro, são os únicos elementos minerais que não são constituintes de estruturas orgânicas. Eles funcionam principalmente na osmorregulação (ex. vacúolos; bomba de $\mathrm{Na} / \mathrm{K}$ ), na manutenção do equilíbrio eletroquímico nas células e seus compartimentos e, na regulação das atividades enzimáticas. É natural que devido a baixa concentração, os micronutrientes não tenham função direta na osmorregulação ou na manutenção do equilíbrio eletroquímico (Malavolta, 2006).

\section{Potássio (k)}

O macronutriente potássio mostrou concentração mínima de $1.738,0 \mathrm{mg}$ $\mathrm{kg}^{-1}$ e máxima de $20.572,0 \mathrm{mg} \mathrm{kg}^{-1}$ (Tabela 12) na parte aérea do campo MP, no verão e inverno de 2009, respectivamente. Estes valores podem estar correlacionados com o nível de inundação e salinidade nos dias de coleta do campo que, no verão, em maré baixa a salinidade do campo estava bem próxima da água superficial de $\mathrm{CH}$, enquanto que no inverno, a salinidade do campo encontrava-se um pouco superior ao $\mathrm{CH}$, sendo que o campo do MP apresenta condições oligohalinas.

O potássio é um elemento envolvido no controle de abertura e fechamento de estômatos através de alterações da turgidez das células guarda induzidas por uma bomba de potássio na parede celular. Como os estômatos são importantes estruturas que atuam na regulação da perda de água pelas plantas, o potássio ajuda a diminuir perdas de água e aumenta a tolerância a secas (Malavolta, 2006). Dessa forma, a variação climática entre o período úmido (verão de 2009) e o 
período seco (inverno de 2009) pode condicionar a quantificação do K na estrutura aérea da Spartina, controlada pelos estômatos.

O campo PA apresentou concentrações crescentes na parte aérea observadas do período verão 2009 (7.092 $\left.\mathrm{mg} \mathrm{kg}^{-1}\right)$ ao verão de 2010 (14.853,7 mg $\mathrm{kg}^{-1}$ ) passando pelo inverno de 2009 (12.275,6 mg kg-1) (Tabela 12). O mesmo incremento sazonal pôde ser observado nesse campo para a parte subterrânea do vegetal, como mostra a Tabela 12, porém a ordem de grandeza foi bem menor, o que deve estar associado à ausência de estômatos na raiz.

O campo IC também apresentou as mesmas oscilações de concentração que o campo da PA. Entre o período de inverno de 2009 e o verão de 2010 a concentração parte aérea passou de $9.630,1 \mathrm{mg} \mathrm{kg}^{-1}$ para $12.458,3 \mathrm{mg} \mathrm{kg}^{-1}$. Na parte subterrânea da planta, a raiz concentrou 4.192,6 $\mathrm{mg} \mathrm{kg}^{-1}$ no inverno de 2009 e passou a $8.800 \mathrm{mg} \mathrm{kg}^{-1}$ no verão de 2010 .

Observando os campos PA e IC nos períodos em que se obtiveram resultados das duas áreas vegetais, observa-se a maior concentração do $\mathrm{K}$ na parte aérea da planta que está em contato direto com o corpo hídrico e a atmosfera realizando as trocas iônicas possíveis (Figura 26).

Uma característica importante do potássio é a alta taxa com que ele é absorvido pelos tecidos das plantas. Essa rápida absorção de potássio é dependente da permeabilidade ao potássio relativamente alta das membranas das plantas, a qual provavelmente resulta de ionóforos que tornam possível sua difusão facilitada (Mengel \& Kirkby, 1987).

A alta permeabilidade das membranas das plantas ao potássio é a única característica a qual é provavelmente importante para vários processos fisiológicos influenciados pelo potássio, tais como: crescimento meristemático, distribuição da água, fotossíntese e transporte à longas distâncias. O transporte do potássio é, com freqüência, atribuído aos tecidos jovens, ocorrendo freqüentemente translocação das folhas mais velhas para as partes mais jovens das plantas (Mengel \& Kirkby, 1987). O potássio é absorvido principalmente durante o estágio de crescimento vegetativo. Essa alta taxa de absorção do 
potássio pressupõe que existe uma forte competição com a absorção de outras espécies de cátions e as taxas de absorção deles são especialmente aumentadas, quando absorção de potássio é baixa (Grimme et al ., 1974)

A absorção do potássio é altamente seletiva e está intimamente acoplada à atividade metabólica. Este elemento no solo aparece na forma iônica $\left(\mathrm{K}^{+}\right)$, sendo esta a forma absorvida pelas raízes das plantas e é transportado pelos compartimentos da planta como $\mathrm{K}^{+}$, ou seja, na mesma forma em que é absorvido do solo. Como o potássio é um íon monovalente, ao competir com elevadas concentrações de cátions divalentes como $\circ \mathrm{Ca}^{++}$e $\circ \mathrm{Mg}^{++}$sofre inibição competitiva, ou seja, compete com desvantagem pelo mesmo sítio de absorção. Entretanto, baixas concentrações de cálcio contribuem para sua absorção (efeito sinergístico). O íon é caracterizado pela alta mobilidade nas plantas, em todos os níveis, dentro da célula, dentro dos tecidos, e é transportado à longa distância via xilema e floema. Isto acontece, porque o potássio não faz parte permanente de nenhum composto orgânico (função estrutural) (Prado, 2009).

O mesmo padrão apresentado pelas oscilações de concentração dos campos anteriores, o campo $\mathrm{Bl}$ também teve incremento da concentração de $\mathrm{K}$ entre uma estação e outra. A parte aérea (Figura 26) teve a concentração de $10.415,3 \mathrm{mg} \mathrm{kg}^{-1}$ no verão de 2009, passou a $11.921,0 \mathrm{mg} \mathrm{kg}^{-1}$ no inverno de 2009 e chegou as $13.875,8 \mathrm{mg} \mathrm{kg}^{-1}$ no verão de 2010 (Tabela 12). Observa-se, juntamente com incremento da concentração do potássio, o crescimento médio da altura dos indivíduos desse campo, sendo que no verão a altura média dos indivíduos foi $34 \mathrm{~cm}$ e, no inverno de $45 \mathrm{~cm}$ e ainda, no verão de 2010 foi de 66 $\mathrm{cm}$.

Adaime (1978) encontrou maior porcentagem de potássio no material vivo do que no morto na Spartina do campo da PA. A máxima porcentagem de K para o material vivo ocorreu em maio, com $2,62 \%$, seguindo uma queda nos meses monitorados até setembro. 
Pelo método de Ativação Neutrônica, não é possível determinar a forma em que o elemento se encontra na estrutura do vegetal, de forma que temos o valor total de $\mathrm{K}$.

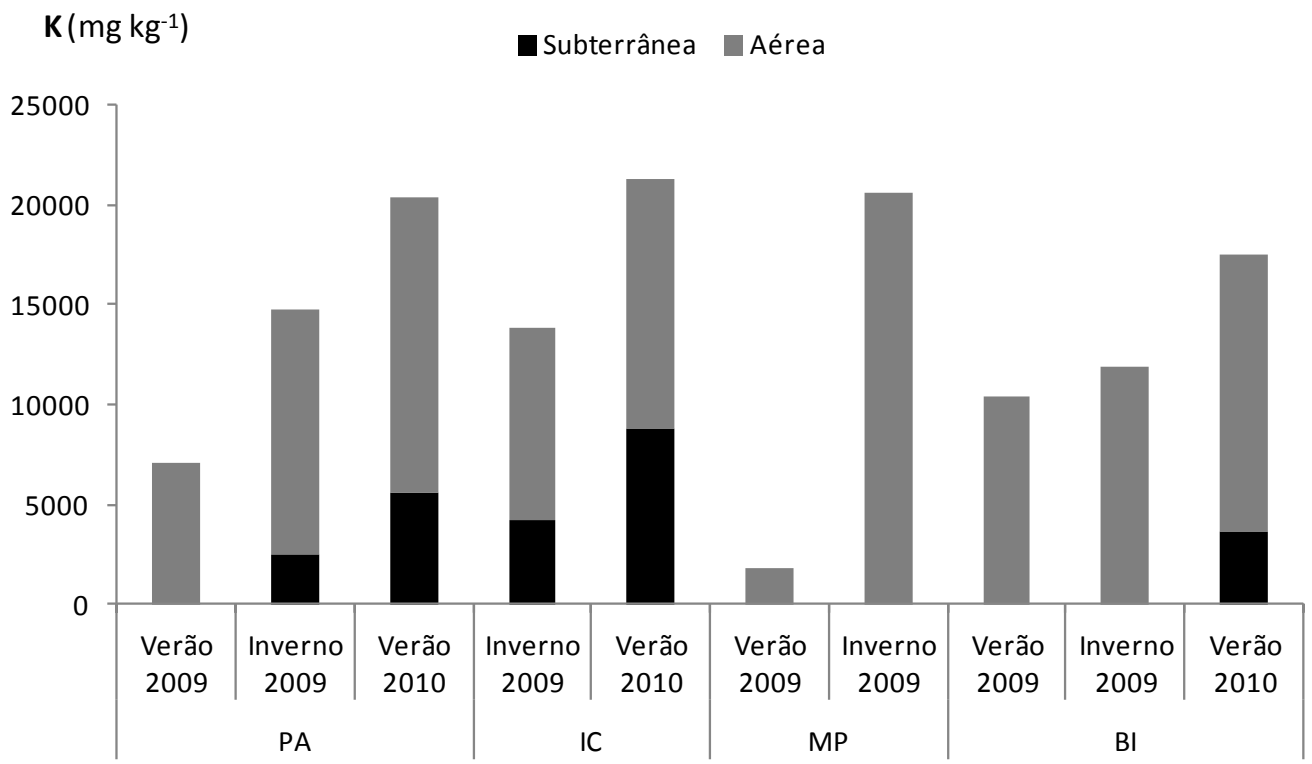

Figura 26. Concentrações de $\mathrm{K}\left(\mathrm{mg} \mathrm{kg}^{-1}\right)$ da parte aérea e subterrânea da $S$. alterniflora nos campos Ponta do Arrozal (PA), Ilha Comprida (IC), Mar Pequeno (MP) e Barra do Icapara (BI) nos períodos de verão em inverno de 2009 e verão de 2010

\section{- Cálcio (Ca)}

As maiores concentrações de cálcio foram obtidas na parte subterrânea da planta (Figura 27). Enquanto a parte aérea da $S$. alterniflora no campo PA concentrou 1.304,0 $\mathrm{mg} \mathrm{kg}^{-1}$ no verão de 2.009, 1.887,9 $\mathrm{mg} \mathrm{kg}^{-1}$ no inverno de 2009 e $2.002,8 \mathrm{mg} \mathrm{kg}^{-1}$ no verão de 2.010, a raiz concentrou neste campo $2.485,0 \mathrm{mg}$ $\mathrm{kg}^{-1}, 3.131,6 \mathrm{mg} \mathrm{kg}^{-1}$ e 2.626,5 $\mathrm{mg} \mathrm{kg}^{-1}$, respectivamente para os mesmo períodos. Observa-se assim, que as raízes apresentaram maiores valores de $\mathrm{Ca}$.

A forma absorvida pela planta é a iônica de $\mathrm{Ca}^{++}$, existentes na solução do solo e é diminuída pela competição iônica da presença de altas concentrações de 
$\mathrm{K}^{+}$e $\mathrm{Mg}^{++}$no meio. O conteúdo de cálcio nas plantas varia entre 0,1 a $5,0 \%$ do peso seco dependendo das condições de crescimento (Malavolta, 2006).

O cálcio possui baixa mobilidade no solo e na planta, desta forma, a região de absorção se resume apenas nas extremidades das radicelas (células da raiz). A relativa imobilidade do cálcio faz com que ele não se redistribua com facilidade no vegetal quando há carência no sistema radicular, em conseqüência, os sintomas de carência aparecem primeiramente nas folhas e órgãos ou partes novas da planta (Fernandez, 2006). Essa baixa mobilidade de cálcio no sistema da planta provavelmente deve ocorrer também na $S$. alterniflora que, demonstra maiores teores de $\mathrm{Ca}$ na região radicular que na região aérea, como citado anteriormente. Os teores de cálcio na raiz chegaram a ser 2 vezes superiores (campo da IC, inverno de 2009) em relação a parte aérea da macrófita.

Os campos IC, MP e BI também refletiram esse comportamento de maior concentração de Ca na região subterrânea da $S$. alternifora.

A maioria das funções desempenhadas pelo cálcio é como componente estrutural de macromoléculas, e está relacionada com a capacidade de coordenação, que estabelece ligações intermoleculares estáveis, mas reversíveis na parede celular e na membrana plasmática. Isto explica os baixos níveis de $\mathrm{Ca}$ no floema e da baixa ou nula redistribuição do $\mathrm{Ca}$ na planta. Esta baixa redistribuição do $\mathrm{Ca}$ faz com que os sintomas de carência do elemento apareça em órgãos e partes mais jovens (Malavolta, 2006). 


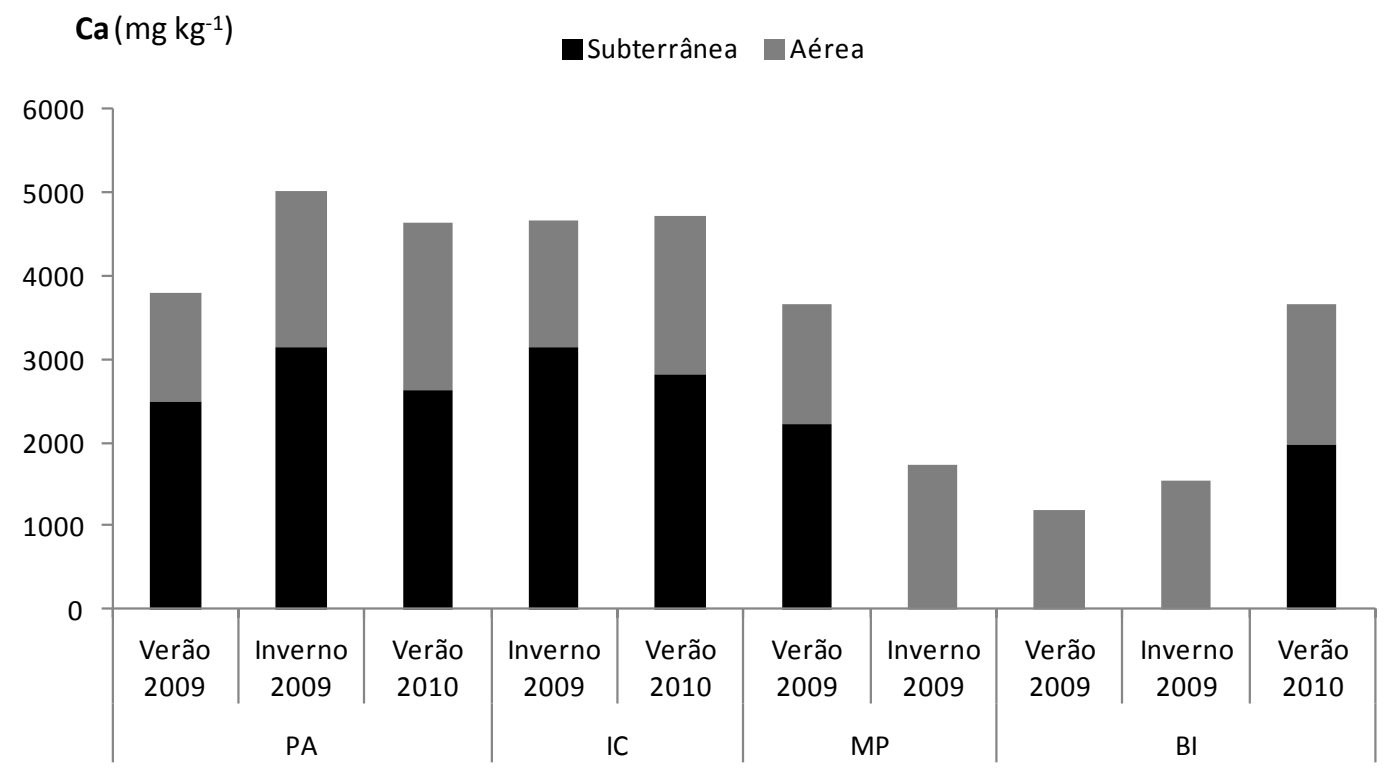

Figura 27. Concentrações de Ca $\left(\mathrm{mg} \mathrm{kg}^{-1}\right)$ da parte aérea e subterrânea da $S$. alterniflora nos campos Ponta do Arrozal (PA), Ilha Comprida (IC), Mar Pequeno (MP) e Barra do Icapara $(\mathrm{BI})$ nos períodos de verão em inverno de 2009 e verão de 2010

\section{- Ferro (Fe)}

A concentração aérea média do ferro na $S$. alterniflora da região sul ficou em 223,7 mg kg-1 enquanto que, no setor norte, a concentração média dos campos MP e Bl foi de $424,8 \mathrm{mg} \mathrm{kg}^{-1}$ e a concentração máxima da porção aérea de $671,2 \mathrm{mg} \mathrm{kg}^{-1}$ ocorreu no campo MP, no período de inverno de 2009.

A área radicular da macrófita mostrou concentração média de 3863,3 mg $\mathrm{kg}^{-1}$ no setor sul, enquanto o setor norte registrou a média de $19.970,5$ mg kg ${ }^{-1}$. Nesta parte subterrânea da planta, a concentração máxima de ferro foi de 24.029,0 mg kg-1 no campo MP. Observa-se que as concentrações da raiz são muito superiores às concentrações da área exposta. Foi verificado um valor de ferro 60 vezes maior no tecido da raiz que no tecido aéreo, em indivíduos do campo MP.

Alberts et al. (1990) encontraram em $S$. alterniflora da região portuária da Georgia (EUA), a concentração máxima de $3.030 \mu \mathrm{g} \mathrm{g}^{-1}$ e a mínima de $417 \mu \mathrm{g} \mathrm{g}^{-1}$ na raiz enquanto que na parte foliar da planta foi encontrado a concentração 
máxima de $385 \mu \mathrm{g} \mathrm{g}^{-1}$ e a mínima de $128 \mu \mathrm{g} \mathrm{g}^{-1}$. Mudanças nas condições do potencial redox e pH do sedimento podem causar alterações na especiação e solubilidade de metais, o que resulta num fluxo dos sedimentos para a água intersticial e supersatura a água e/ou aumenta a absorção pelas plantas. É possível que as variações de salinidade também possam alterar a especiação química e conseqüentemente, a absorção de metal, mas Drifmeyer \& Redd (1981) encontraram fraca correlação entre a concentração de ferro e o gradiente de salinidade no estuário do rio York, onde a concnetração de ferro na S. alterniflora variou de $1050 \mu \mathrm{g} \mathrm{g}^{-1}$ até $120 \mu \mathrm{g} \mathrm{g}^{-1}$ da região menos halina para a mais halina.

No presente estudo, observam-se as maiores concentrações de ferro na região de oligohalina a dulcícola, respectivamente nos campos $\mathrm{BI}$ e MP, do setor norte como também, as maiores concentrações para da parte radicular do vegetal (Erro! Fonte de referência não encontrada.). A absorção de ferro pelas plantas é metabolicamente controlada e ele pode ser absorvido como $\mathrm{Fe}^{3+}, \mathrm{Fe}^{2+}$ e $\mathrm{Fe}-$ quelato. A capacidade das raízes em reduzir $\mathrm{Fe}^{3+}$ para $\mathrm{Fe}^{2+}$ parece ser fundamental na absorção deste cátion por muitas plantas. Uma característica marcante das raízes de algumas macrófitas de marismas é a presença da rizoconcentração de metais ou plaquetas nas raízes (Mendelssohn \& Postek, 1982; Vale et al., 1990).

De acordo com Lacerda et al. (1993) o sedimento sob S. alterniflora da baía de Sepetiba $(R J)$ concentrou em média 1,5\% de ferro, ocorrendo também em condições onde os teores de matéria orgânica estavam em torno de 5,5\%, em solos aerados e o ferro estava ligado a outras substâncias. Estas outras estruturas são compostas principalmente por hidróxidos de ferro e outros metais como manganês que são mobilizados e precipitados na superfície radicular. Os metais são mobilizados do sedimento estuarino anóxido e concentrados em microambientes oxidados ao redor das raízes (Weis \& Weis, 2004). 


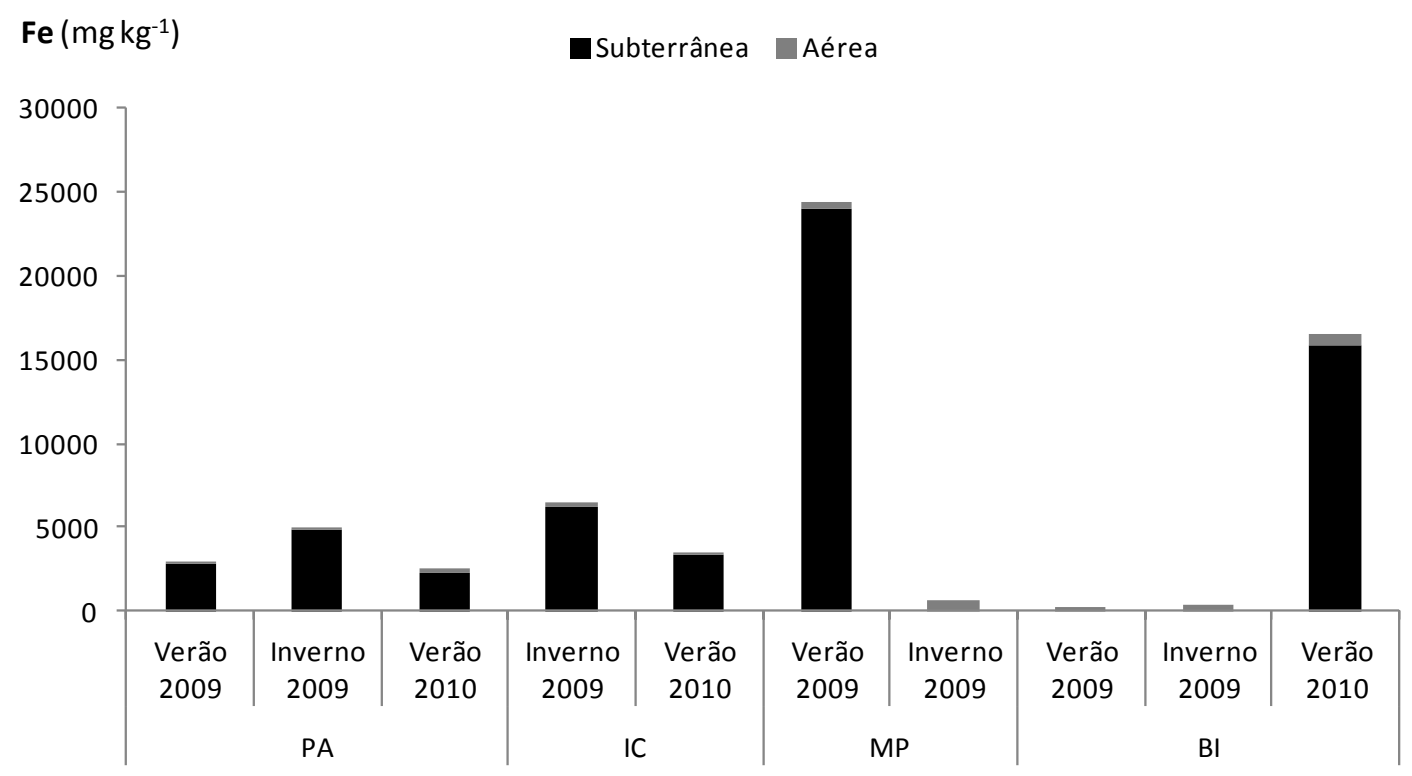

Figura 28. Concentrações de $\mathrm{Fe}\left(\mathrm{mg} \mathrm{kg}^{-1}\right)$ da parte aérea e subterrânea da $S$. alterniflora nos campos Ponta do Arrozal (PA), Ilha Comprida (IC), Mar Pequeno (MP) e Barra do Icapara (BI) nos períodos de verão em inverno de 2009 e verão de 2010.

\section{- Zinco (Zn)}

As maiores concentrações do zinco na parte aérea da $S$. alterniflora foram encontradas no verão de 2010, a máxima foi de 20,0 $\mathrm{mg} \mathrm{kg}^{-1}$ nos campos PA e Bl. Isso mostra não haver uma diferença entre os dois setores, embora haja um incremento na concentração entre os períodos trabalhados (Figura 29). No campo PA a concentração do zinco mostrou valores de 16,7 mg $\mathrm{kg}^{-1}$ no verão de 2009, no inverno deste ano foi $18,5 \mathrm{mg} \mathrm{kg}^{-1}$ e no verão de 2010 chegou a 20,0 mg kg-1. A concentração nos períodos de verão, época de desenvolvimento da $S$ alterniflora pôde-se notar elevados teores de zinco. No entanto, Gleason et al. (1979) encontraram em S. alterniflora, brotos que acumularam manganês, cobre e zinco rapidamente na primavera e em seguida, os níveis diminuíram. O declínio foi atribuído ao efeito da diluição durante o crescimento.

$\mathrm{Na}$ região foliar, Alberts et al. (1990) encontraram na Spartina do estuário da Geórgia a concentração mínima de $6 \mu \mathrm{g} \mathrm{g}{ }^{-1}$ e a máxima de $146 \mu \mathrm{g}$ 
$\mathrm{g}^{-1}$ de $\mathrm{Zn}$ que juntamente com $\circ \mathrm{Fe}$ e $\mathrm{Mn}$, apresentaram as mesmas proporções de concentração entre a parte aérea e subterrânea do vegetal. Williams et al. (1994) encontraram para a Spartina da região do Mar do Norte (Two Tree Island) a concentração média de zinco na raiz de $108 \mu \mathrm{g} \mathrm{g}^{-1}$ e na parte foliar a média foi de $68 \mathrm{\mu g} \mathrm{g}^{-1}$ e em outro estuário estudado (Salcott), as concentrações médias de zinco foram 102 e $51 \mathrm{\mu g} \mathrm{g}^{-1}$ para a parte da raiz e folha, respectivamente.

$\mathrm{Na}$ área radicular da Spartina, na região do $\mathrm{CELCI}$, as concentrações do zinco foram superiores à da parte foliar, a diferença chegou a 2,5 vezes mais zinco na parte subterrânea do campo PA no inverno de 2009, cujo valor máximo encontrado foi de $45,5 \mathrm{mg} \mathrm{kg}^{-1}$.

O Zn nos solos de regiões tropicais encontra-se em grande parte adsorvido na matéria orgânica e argila. Ele é absorvido pelas raízes das plantas na forma bivalente $\left(\mathrm{Zn}^{2+}\right)$, embora em pH mais alto este elemento pode ser absorvido na forma de hidróxido de $\mathrm{Zn}\left(\mathrm{ZnOH}^{+}\right)$(Malavolta, 2006). Segundo Williams et al., 1994, a concentração de metais (Cd, Pb, Fe, Mn) encontrada no sedimento não foi refletida na concentração do vegetal, exceto para o Zn que, por não estar na forma disponível ou pelo fato da macrófita ter a habilidade em controlar a absorção desse elemento, o metal apresentou baixas concentrações. Entretanto, Hempel et al. (2008) encontraram concentrações do $\mathrm{Zn}$ na parte subterrânea da gramínea muito superiores à parte aérea, os teores foram de $27 \mu \mathrm{g} \mathrm{g}^{-1}$ na raiz e $46 \mu \mathrm{g} \mathrm{g}^{-1}$ na área foliar e 19 e $75 \mu \mathrm{g} \mathrm{g}^{-1}$ para outro campo da região da Bahia Blanca (Argentina). Isto mostra que o processo de retenção do zinco ocorre primeiramente na raiz e rizomas da $S$. alterniflora. 


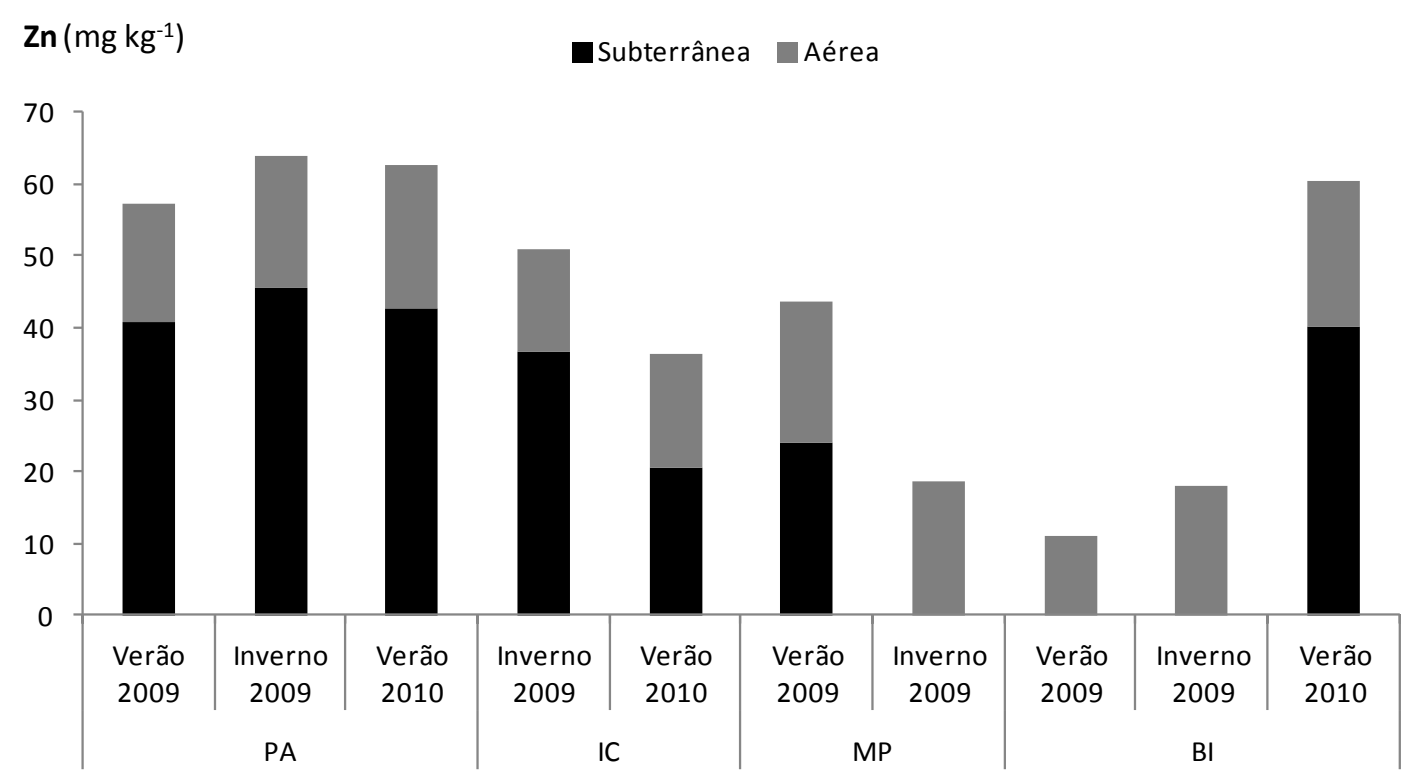

Figura 29. Concentrações de $\mathrm{Zn}\left(\mathrm{mg} \mathrm{kg}^{-1}\right)$ da parte aérea e subterrânea da $S$. alterniflora nos campos Ponta do Arrozal (PA), llha Comprida (IC), Mar Pequeno (MP) e Barra do Icapara (BI) nos períodos de verão e inverno de 2009 e verão de 2010.

\section{- Cromo (Cr)}

O campo PA, no setor sul do CELCl apresentou $689,7 \mathrm{\mu g} \mathrm{kg}^{-1}$ de cromo na parte aérea da gramínea em agosto de 2009, já para o verão de 2010 a concentração foi a $1662,9 \mathrm{\mu g} \mathrm{kg}^{-1}$, havendo assim um incremento da concentração do metal nas folhas e caule, entre a estação de menor e maior produtividade vegetal (Figura 30). Na área subterrânea, as concentrações foram de 3.019,0 $\mu \mathrm{g}$ $\mathrm{kg}^{-1}$, 8.890,9 $\mathrm{\mu g} \mathrm{kg}^{-1}$ e 4.048,0 $\mathrm{\mu g} \mathrm{kg}^{-1}$ para os respectivos períodos de verão e inverno de 2009 e verão de 2010. O acúmulo do metal na área radicular foi 13 vezes superior que na região aérea. Observando esse campo, que apresenta a série temporal mais completa de dados do metal, pode-se inferir a maior retenção de cromo na fase de crescimento do vegetal.

Em dois estuários de Portugal, Caetano et al. (2008) encontraram teores de cromo na Spartina marítima, em seus tecidos aéreo e subterrâneo sendo no primeiro ambiente registrada a variação de 1,4-2,0 $\mathrm{\mu g} \mathrm{g}^{-1}$ no tecido foliar, enquanto a parte radicular teve a variação de $20-33 \mu \mathrm{g} \mathrm{kg}^{-1}$. No segundo estuário, os teores 
encontrados no tecido aéreo variaram de $1,0-3,8 \mu \mathrm{g} \mathrm{kg}^{-1}$ e no tecido subterrâneo, as concentrações foram de $11-30 \mu \mathrm{g} \mathrm{kg}^{-1}$, ou seja, as concentrações no tecido radicular foram de 2-4 ordens de grandeza superiores à parte aérea, provando assim o fraco translocamento para a parte superior da $S$. maritima. Esses autores (op. cit.) também verificaram a variação de profundidade da concentração de metais no sedimento ao redor da raiz, e observaram que as concentrações dependem da composição do sedimento, da atividade biológica do metal com a água intersticial/sedimento e da competição com os óxidos de ferro que se precipitam ao redor das raízes. Presumivelmente, o solúvel tóxico $\mathrm{Cr}$ (IV) se reduz ao Cr (III) estável e é retido em sedimento sólido como hidróxido de cromo, não fazendo mais sua mobilização pelas raízes.

A concentração máxima de cromo na parte aérea da $S$. alterniflora obtida para o setor sul foi $1.662,9 \mathrm{\mu g} \mathrm{kg}^{-1}$ no verão de 2010 , enquanto que no setor norte a maior concentração de $\mathrm{Cr}$ ocorreu no campo MP no inverno de $2009 \mathrm{com}$ $1.215,3 \mu \mathrm{g} \mathrm{kg}^{-1}$. Já para a parte subterrânea da gramínea, a maior concentração do setor sul foi obtida no inverno de 2009 no campo PA e para o setor norte, a maior concentração registrada de cromo na raiz da S.alterniflora. foi de $2.475,0 \mu \mathrm{g}$ $\mathrm{kg}^{-1}$ no campo MP, no verão de 2009 . 


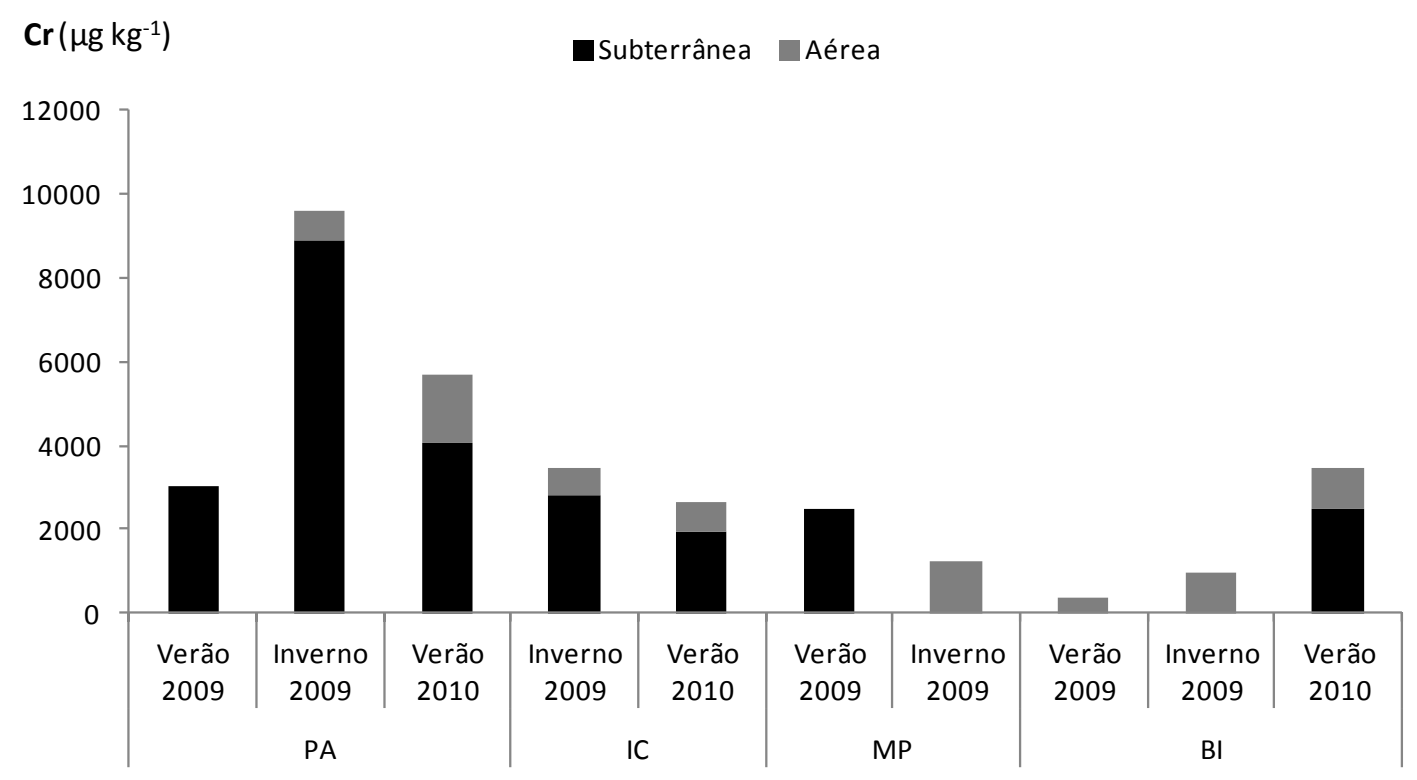

Figura 30. Concentrações de $\mathrm{Cr}\left(\mu \mathrm{g} \mathrm{kg}^{-1}\right)$ da parte aérea e subterrânea da $\mathrm{S}$. alterniflora nos campos Ponta do Arrozal (PA), llha Comprida (IC), Mar Pequeno (MP) e Barra do Icapara (BI) nos períodos de verão e inverno de 2009 e verão de 2010.

\subsection{Dados de $\mathrm{Hg}, \mathrm{Cd}$ e $\mathrm{Pb}$ em S. alteniflora}

As concentrações dos elementos obtidos pela Espectrometria de Absorção Atômica encontram-se dispostos na Tabela 13. Os elementos chumbo, cádmio e mercúrio foram analisados quanto às diferenças entre os setores do Complexo Estuarino-Lagunar de Cananéia-Iguape, quanto à sazonalidade e quanto às diferenças da área vegetal da Spartina alterniflora, a parte aérea (foliar) e a parte subterrânea (radicular). 
Tabela 13: Concentrações de $\mathrm{Pb}, \mathrm{Cd}$ e $\mathrm{Hg}$ encontrados nas partes aérea e subterrânea da S. alterniflora nas regiões de Cananéia e Iguape.

\begin{tabular}{|c|c|c|c|c|c|c|c|c|c|}
\hline Área vegetal & Setor & Campo & Período & $\mathrm{Pb}\left(\mathrm{mg} \mathrm{kg}^{-1}\right)$ & $\pm \mathrm{Pb}$ & $\mathrm{Cd}\left(\mathrm{mg} \mathrm{kg}^{-1}\right)$ & $\pm \mathrm{Cd}$ & $\mathrm{Hg}\left(\mathrm{mg} \mathrm{kg}^{-1}\right)$ & $\pm \mathrm{Hg}$ \\
\hline \multirow{9}{*}{$\frac{i \frac{\bar{\sigma}}{0}}{i}$} & \multirow{5}{*}{$\begin{array}{c}\text { Sul } \\
\text { (Cananéia) }\end{array}$} & \multirow{2}{*}{ PA } & Verão 2009 & 0,322 & 0,008 & 0,009 & 0,001 & 0,001 & 0,000 \\
\hline & & & Verão 2010 & 0,447 & 0,026 & 0,016 & 0,001 & 0,001 & 0,001 \\
\hline & & \multirow{3}{*}{ IC } & Verão 2009 & 0,068 & 0,016 & 0,003 & 0,000 & 0,002 & 0,001 \\
\hline & & & Inverno 2009 & 0,194 & 0,001 & 0,013 & 0,000 & 0,002 & 0,001 \\
\hline & & & Verão 2010 & 0,205 & 0,009 & 0,011 & 0,001 & 0,002 & 0,001 \\
\hline & \multirow{4}{*}{$\begin{array}{c}\text { Norte } \\
\text { (lguape) }\end{array}$} & MP & Verão 2009 & 1,469 & 0,019 & 0,018 & 0,000 & 0,001 & 0,001 \\
\hline & & & Verão 2009 & 0,483 & 0,006 & 0,026 & 0,001 & 0,002 & 0,000 \\
\hline & & $\mathrm{BI}$ & Inverno 2009 & 0,150 & 0,017 & 0,017 & 0,000 & 0,003 & 0,001 \\
\hline & & & Verão 2010 & 0,475 & 0,154 & 0,010 & 0,001 & 0,002 & 0,001 \\
\hline \multirow{5}{*}{ 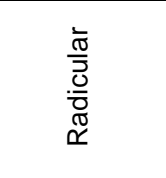 } & \multirow{3}{*}{$\begin{array}{c}\text { Sul } \\
\text { (Cananéia) }\end{array}$} & PA & Verão 2010 & 3,509 & 0,047 & 0,179 & 0,013 & 0,001 & 0,001 \\
\hline & & \multirow{2}{*}{ IC } & Inverno 2009 & 4,059 & 0,183 & 0,139 & 0,003 & 0,004 & 0,000 \\
\hline & & & Verão 2010 & 1,486 & 0,058 & 0,026 & 0,004 & 0,001 & 0,000 \\
\hline & \multirow{2}{*}{ Norte (lguape) } & \multirow{2}{*}{$\mathrm{BI}$} & Inverno 2009 & 5,130 & 0,229 & 0,213 & 0,003 & 0,006 & 0,001 \\
\hline & & & Verão 2010 & 6,102 & 0,418 & 0,198 & 0,001 & 0,012 & 0,001 \\
\hline
\end{tabular}

\section{- Chumbo (Pb)}

As concentrações de chumbo no tecido aéreo no campo PA foram de $0,322 \mathrm{mg} \mathrm{kg}^{-1}$ no verão de 2009 para $0,447 \mathrm{mg} \mathrm{kg}^{-1}$ no verão de 2010 , mostrando incremento desse metal entre os dois períodos (Tabela 13). Enquanto no campo IC as concentrações oscilaram de $0,68 \mathrm{mg} \mathrm{kg}^{-1}, 0,194 \mathrm{mg} \mathrm{kg}^{-1}$ e $0,205 \mathrm{mg} \mathrm{kg}^{-1}$, respectivamente para os períodos de verão e inverno de 2009 e verão de 2010.

A máxima concentração encontrada no setor sul para o tecido aéreo foi de 0,447 $\mathrm{mg} \mathrm{kg}^{-1}$ no campo da PA (Verão 2010) enquanto que no setor norte, a máxima concentração de chumbo foi $1,469 \mathrm{mg} \mathrm{kg}^{-1}$ registrada no tecido aéreo do campo MP (Verão 2009) (Figura 31).

O campo $\mathrm{BI}$ teve oscilações da concentração da parte aérea do chumbo em $0,483 \mathrm{mg} \mathrm{kg}^{-1}, 0,150 \mathrm{mg} \mathrm{kg}^{-1}$ e $0,475 \mathrm{mg} \mathrm{kg}^{-1}$ para os respectivos períodos trabalhados no presente estudo. E esse campo registrou as duas maiores concentrações do tecido subterrâneo da Spartina, no inverno de 2009 foi de 5,13 $\mathrm{mg} \mathrm{kg}^{-1}$ e no verão de 2010 a concentração de $\mathrm{Pb}$ nas raízes foi de $6,102 \mathrm{mg} \mathrm{kg}^{-1}$. As concentrações chegaram a ser 34 vezes superiores ao tecido aéreo.

De acordo com Williams et al. (1994), as proporções da concentração entre raiz e folhas também foram altas, para o estuário Two Tree Island no Mar do 
Norte encontraram 2,9 $\mu \mathrm{g} \mathrm{kg}^{-1}$ na folha e $4,4 \mu \mathrm{g} \mathrm{kg}^{-1}$ na raiz. Para o estuário de Salcott, também no Mar do Norte, as concentrações de chumbo foram 0,95 $\mathrm{\mu g} \mathrm{kg}^{-1}$ na folha e $7,1 \mu \mathrm{g} \mathrm{kg}^{-1}$ na raiz. Isso mostra o chumbo super concentrado na região subterrânea da Spartina.

Para o setor sul, que só foi observado concentrações de chumbo no tecido radicular do campo IC, as concentrações foram relativamente altas sendo que, no inverno de 2009 registrou $4,059 \mathrm{mg} \mathrm{kg}^{-1}$ e no verão de 2010 a concentração reduziu e esteve em $1,486 \mathrm{mg} \mathrm{kg}^{-1}$. Estas concentrações foram extremamente elevadas se comparadas à região aérea da gramínea, no inverno de 2009 a proporção foi 21 vezes superiores no tecido subterrâneo.

Segundo Windham et al. (2001), as concentrações de chumbo também foram superiores no tecido subterrâneo em relação à parte aérea, mesmo em amostras retiradas do ambiente como também em seu experimento. Já Reboreda et al. (2008) encontraram essa superacumulação de chumbo nas raízes da $S$. maritima em três regiões estuarinas de Portugal.

Para a área de estudo do presente trabalho, as maiores concentrações de chumbo foram registradas no setor norte, já conhecido pelo seu histórico de mineração do metal. O chumbo que é lixiviado do solo e dos antigos depósitos chega ao sistema estuarino e deposita. Diversos autores encontraram forte relação do metal do sedimento e a alta concentração no sistema radicular da Spartina. Lacerda et al. (1993) encontraram no sedimento ao redor das raízes 8,0 $\mu \mathrm{g} \mathrm{g}^{-1}$ de chumbo na baía de Sepetiba, região portuária do RJ, enquanto que Burke et al. (2000) encontraram 165,5 $\mathrm{g} \mathrm{g}^{-1}$ de chumbo no sedimento de canais estuarinos de Nova York. Entretanto, os metais não se mantém inertes no sedimento, as plantas a partir do sistema radicular rapidamente alteram as condições redox e criam uma atmosfera oxida propicia à acumulação (Lacerda et al.1997).

A absorção de $\mathrm{Pb}$ é regulada pelo $\mathrm{pH}$, tamanho de partículas e capacidade de troca de cátions dos solos, potencial redox, assim como pela exsudação e outros parâmetros físicoquímicos (Windham, 2001). Excesso de Pb 
causa vários sintomas de toxicidade em plantas, por exemplo: redução de crescimento, clorose e escurecimento do sistema radicular. $\mathrm{Pb}$ inibe a fotossíntese, altera a nutrição mineral e o balanço hídrico, modifica o estado hormonal e afeta a estrutura e permeabilidade da membrana.



Figura 31. Concentrações de $\mathrm{Pb}\left(\mathrm{mg} \mathrm{kg}^{-1}\right)$ da parte aérea e subterrânea da $\mathrm{S}$. alterniflora nos campos Ponta do Arrozal (PA), llha Comprida (IC), Mar Pequeno (MP) e Barra do Icapara (BI) nos períodos de verão e inverno de 2009 e verão de 2010.

\section{- Cádmio (Cd)}

A concentração do $C d$ no campo PA foi $0,009 \mathrm{mg} \mathrm{kg}^{-1}$ no verão de 2009 , enquanto que no verão de 2010 a concentração passou a $0,016 \mathrm{mg} \mathrm{kg}^{-1}$, havendo assim um incremento deste metal no tecido aéreo da $S$. alterniflora. No campo IC, as concentrações foram $0,003 \mathrm{mg} \mathrm{kg}^{-1}$ no verão de $2009,0,013$ no inverno de 2009 e $0,011 \mathrm{mg} \mathrm{kg}^{-1}$ no verão de 2010 (Tabela 13).

Em PA e IC as concentrações do tecido subterrâneo foram 11 vezes superiores ao tecido aéreo nos dois períodos, verão de 2010 e inverno de 2009. As concentrações foram $0,179 \mathrm{mg} \mathrm{kg}^{-1}$ para o campo PA e $0,139 \mathrm{mg} \mathrm{kg}^{-1}$ para o 
campo IC. Williams et al. (1994) também observaram maior concentração do Cd na raiz, com valores de 0,06 e $0,18 \mu \mathrm{g} \mathrm{g}^{-1}$ no tecido aéreo e 0,37 e 1,0 $\mu \mathrm{g} \mathrm{g}^{-1}$ no tecido radicular.

No setor norte, a concentração do $\mathrm{Cd}$ nos tecidos aéreos dos indivíduos foi de $0,018 \mathrm{mg} \mathrm{kg}^{-1}$ e no campo $\mathrm{BI}$, as concentrações foram de $0,026 \mathrm{mg} \mathrm{kg}^{-1}$ no verão de 2009, 0,017 $\mathrm{mg} \mathrm{kg}^{-1}$ no inverno de 2009, sendo que no verão de 2010 houve uma ligeira queda para $0,010 \mathrm{mg} \mathrm{kg}^{-1}$. Hempel et al. (2008) encontraram concentrações do $\mathrm{Cd}$ na parte subterrânea da gramínea próximas à concentração da parte aérea, os teores foram de $0,6 \mu \mathrm{g} \mathrm{g}^{-1}$ na raiz e $0,5 \mu \mathrm{g} \mathrm{g}^{-1}$ na área foliar e 0,10 e $0,8 \mu \mathrm{g} \mathrm{g}^{-1}$ em campo na região da Bahia Blanca (Argentina). No trabalho atual, as concentrações do tecido subterrâneo da região de Iguape chegaram a ser 20 vezes superiores que o tecido foliar. Isto ocorreu no campo BI que, no inverno de $2009\left(0,213 \mathrm{mg} \mathrm{kg}^{-1}\right)$ o maior valor observado na área.

As espécies vegetais, de modo geral, apresentam grande variação quanto à absorção de metais pesados, incluindo o Cd (Hart et al., 1998). As raízes, geralmente, constituem o principal órgão da planta envolvido na absorção e, portanto, quase sempre, as maiores concentrações de metais pesados são, também, encontradas nesta parte da planta (Grant et al., 1998). O que pode ser confirmado pelos valores observados na parte radicular, em Cananéia e Iguape (Fig. 32)

Nas plantas, a presença de Cd em excesso afeta a absorção, transporte e uso de macroelementos como cálcio, fósforo, potássio (Das et al., 1997). Um dos sintomas típicos visíveis da toxidade ao Cd é a clorose foliar (Küpper et al., 2007). A clorose é maior em folhas novas quando comparadas com as mais velhas, indicando que folhas jovens absorvem mais $\mathrm{Cd}$, ou que elas são mais vulneráveis à toxicidade causada por este metal pesado (Küpper et al., 2007). A clorose pode ser devida a uma competição do $\mathrm{Cd}$ com o ferro por sítios de absorção na membrana plasmática ou com magnésio, podendo, neste caso, afetar potencialmente a estabilidade das clorofilas (Kurdziel et al., 2004). 


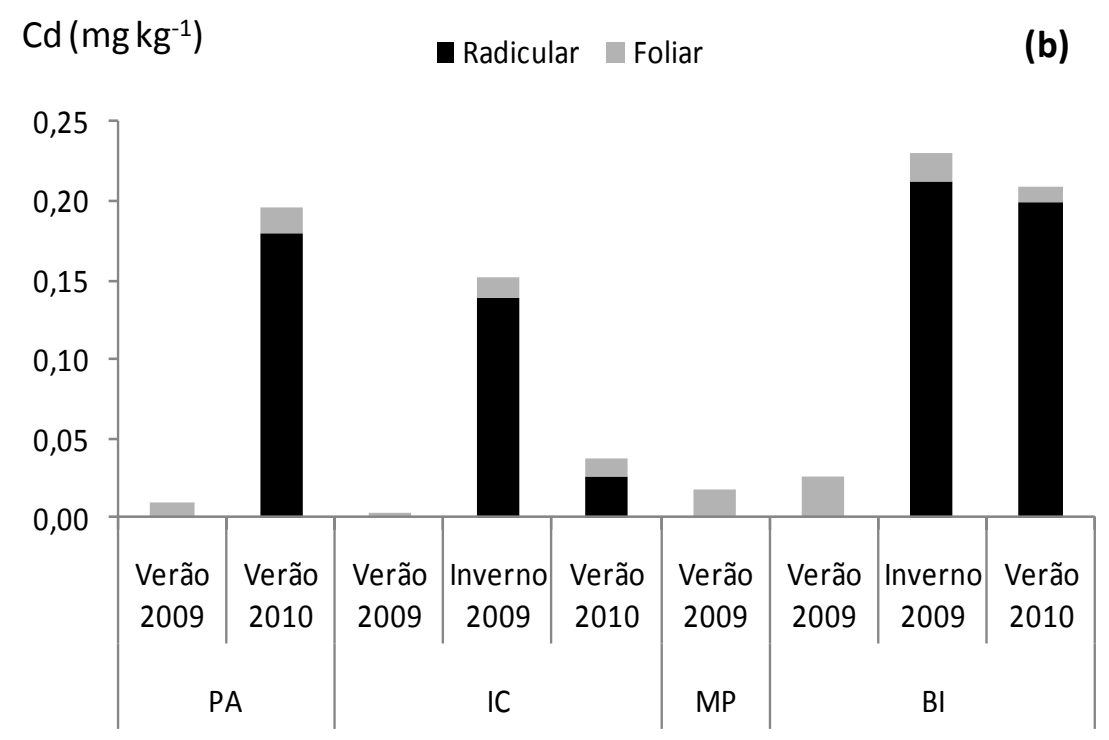

Figura 32. Concentrações de $\mathrm{Cd}\left(\mathrm{mg} \mathrm{kg}^{-1}\right)$ da parte aérea e subterrânea da $S$. alterniflora nos campos Ponta do Arrozal (PA), Ilha Comprida (IC), Mar Pequeno (MP) e Barra do Icapara (BI) nos períodos de verão e inverno de 2009 e verão de 2010.

\section{- Mercúrio $(\mathrm{Hg})$}

Alguns valores de concentração do mercúrio estiveram no limite de detecção (LD) do método (Tabela 13). Todos os resultados do tecido aéreo da $S$. alterniflora nos campos estudados (PA e IC setor sul, MP e BI setor norte) estiveram no LD, enquanto o tecido subterrâneo apresentou valores acima da LD.

O campo PA no verão de 2010 registrou $0,013 \mathrm{mg} \mathrm{kg}^{-1}$ de $\mathrm{Hg}$ na parte subterrânea da planta, enquanto que em Cananéia, o campo IC registrou no 0,004 $\mathrm{mg} \mathrm{kg}^{-1}$ no inverno de 2009.

As maiores concentrações de Hg ocorreram em Iguape, no campo $\mathrm{BI}$, com 0,006 $\mathrm{mg} \mathrm{kg}^{-1}$ no inverno de 2009 e 0,012 $\mathrm{mg} \mathrm{kg}^{-1}$, ou seja, a concentração dobrou de um período para outro (Figura 33). Considerando os resultados de concentração de $\mathrm{Hg}$, os valores na parte subterrânea chegaram a ser 7 vezes maior que no tecido aéreo.

Alberts et al. (1990) encontraram em S. alterniflora da região portuária da Georgia (EUA), a concentração máxima de $0,30 \mu \mathrm{g} \mathrm{g}^{-1}$ e a mínima de $0,14 \mu \mathrm{g} \mathrm{g}{ }^{-1}$ 
na raiz enquanto que na parte foliar da planta foi encontrado a concentração máxima de $0,29 \mu \mathrm{g} \mathrm{g}^{-1}$ e a mínima de $0,12 \mu \mathrm{g} \mathrm{g}{ }^{-1}$.

Mrozek Jr (1980), em experimento laboratorial com S. alterniflora teve a indicação de que o mercúrio e o cádmio reduziram a taxa de germinação, o desempenho total e viabilidade após iniciar estímulo a germinação. O aumento do efeito negativo foi diretamente correlacionado com o aumento do nível de salinidade e concentração de metais. Os resultados também indicaram que a concentração de sal (possivelmente de íons cloreto) tenha influenciando a toxicidade às sementes de $S$. alterniflora.

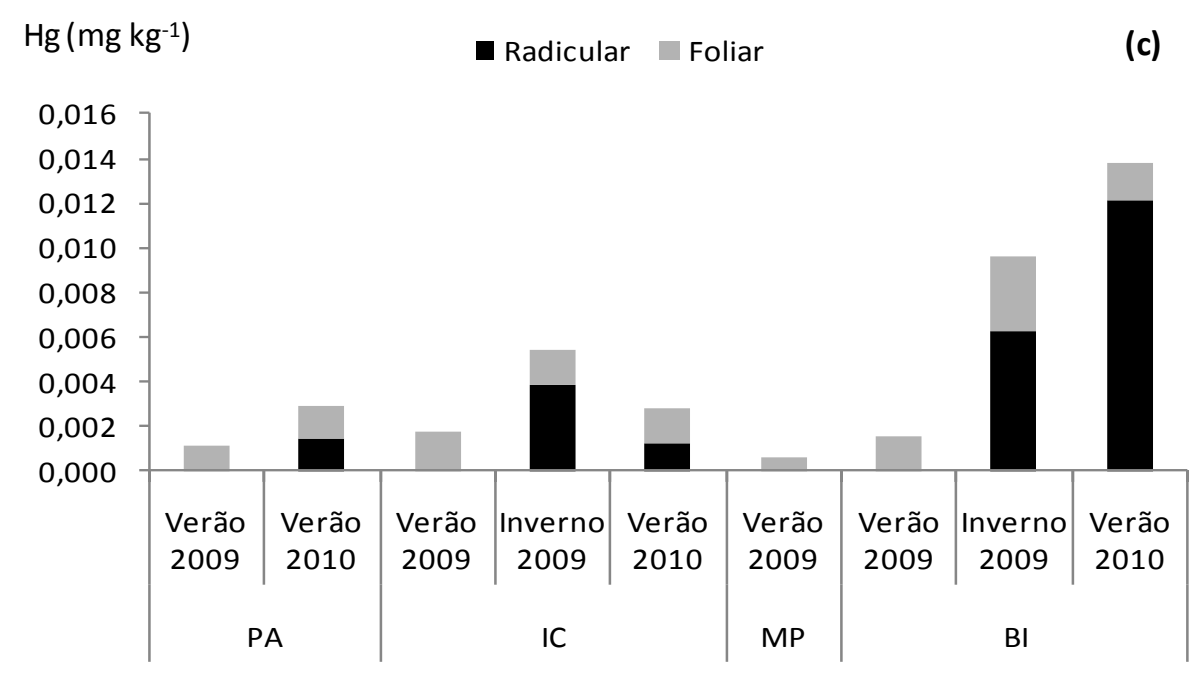

Figura 33. Concentrações de $\mathrm{Hg}\left(\mathrm{mg} \mathrm{kg}^{-1}\right)$ da parte aérea e subterrânea da $\mathrm{S}$. alterniflora nos campos Ponta do Arrozal (PA), llha Comprida (IC), Mar Pequeno (MP) e Barra do Icapara (BI) nos períodos de verão e inverno de 2009 e verão de 2010.

\subsection{Avaliação de clorofila a em S. alterniflora}

Para a determinação da clorofila a em $S$. alterniflora foi feita uma comparação metodológica considerando a eficiência de extração por dois solventes: a acetona $90 \%$ e o dimetil-sulfóxido-DMSO. 
Várias amostras (8) de tecido vegetal provenientes das duas regiões tiveram o pigmento extraído pelos dois solventes e o extrato apresentou pico de absorbância nos mesmos comprimentos de onda 480, 663 e 665nm, como mostra o gráfico de varredura (Figura 34) que sinaliza a maior eficiência de extração de clorofila a em vegetais superiores com o uso de DMSO, retificando uso das fórmulas de Arnon (1949) para os cálculos de clorofila.

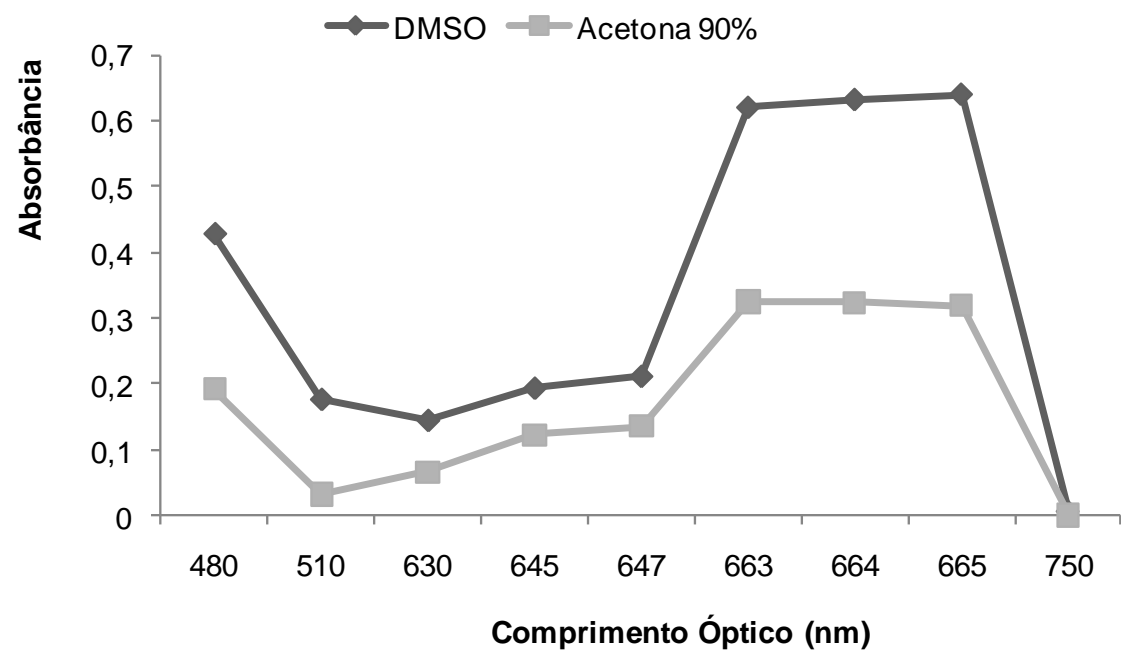

Figura 34: Varredura da absorbância da clorofila a em diversos comprimentos de onda, extraída pelos solventes DMSO e Acetona $90 \%$.

Os resultados da extração da clorofila a pelo método do DMSO foram em média $6 \%$ superiores ao método da acetona, podendo ser visualizados na Figura 35. A utilização do DMSO como solvente extrator pigmentar vegetal mostra ser mais eficiente que a acetona, também mostrado pelos trabalhos de Cruz et al. (2007) e Barnes et al. (1992). Além da eficiência como solvente extrator, o uso de DMSO facilita e agiliza as análises pigmentares, pois este não requer trituração e centrifugação. 


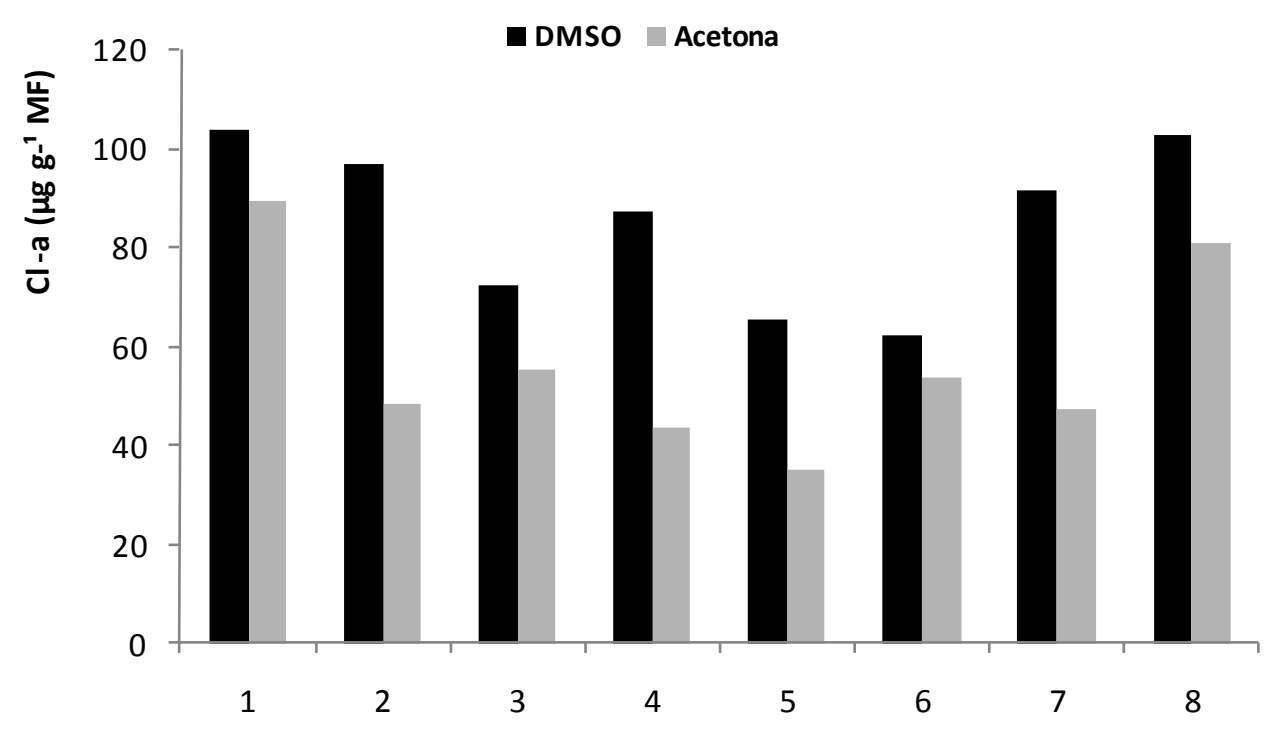

Figura 35: Concentração de clorofila obtidos eplos dois métodos de extração de clorofila a pelos solventes DMSO e acetona para um grupo de 8 amostras coletadas no verão de 2009.

O método de extração por dimetil-sulfóxido foi adotado neste estudo para a determinação de clorofila principalmente devido à redução das etapas de extração, pois não há necessidade de trituração e centrifugação e os extratos são estáveis por um longo período de tempo. Entretanto, a eficiência de extração por DMSO não pode ser recomendada para outras espécies de vegetais sem que haja um teste, uma vez que ocorrem particularidades na anatomia foliar de cada uma.

A utilização de DMSO como solvente para extração clorofílica deve levar em conta o tempo de incubação e a temperatura adequada para a extração para cada espécie vegetal.

No verão de 2009, a extração de clorofila a foi feita utilizando o solvente dimetil-sulfóxido e os bancos de Iguape foram $22 \%$ superiores aos bancos de Cananéia (Figura 36). A maior quantificação de clorofila (Massa Fresca-MF) foi registrada no campo MP que apresentou $102,8 \mu \mathrm{g} \mathrm{g}^{-1}$, já o segundo maior teor de clorofila (MF) do setor norte, o banco BI teve 100,38 $\mu \mathrm{g} \mathrm{g}^{-1}$ em clorofila. 
Os resultados de verão 2009 mostraram maiores concentrações de clorofila a no ambiente caracterizado pela maior alteração antrópica no corpo hídrico do sistema, ou seja, no setor norte, em Iguape.

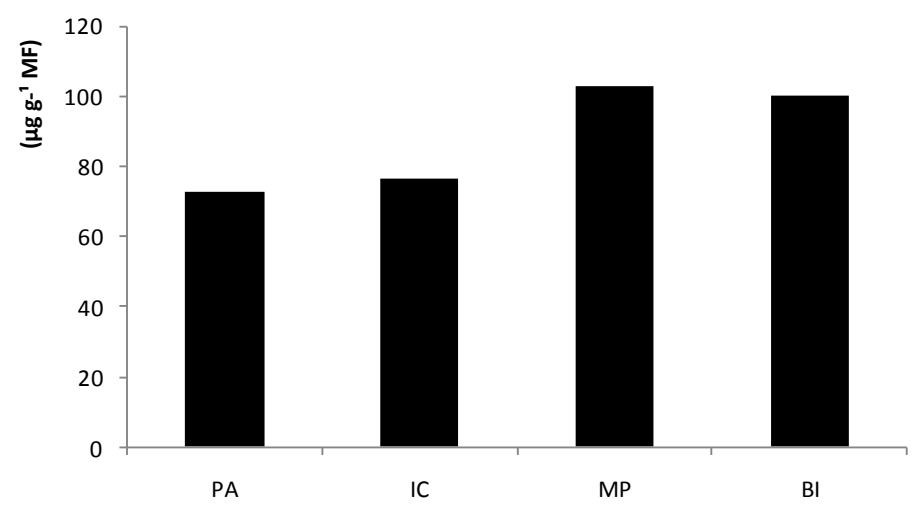

Figura 36: Concentrações de clorofila a, extraída com DMSO, no período de verão 2009, dos quadrantes PA e IC correspondentes ao setor sul (Cananéia), MP referente ao Mar Pequeno e BI (lguape).

No período de Inverno de 2009 não foram realizadas extrações de clorofila com acetona, somente com o DMSO. Nesse período os resultados de clorofila a já demonstram haver uma equiparação entre os teores pigmentares dos setores norte e sul do CELCI. Na região sul, o campo PA teve uma ligeira superioridade pigmentar (6\%), embora os campos IC e MP tenham respectivamente 55 e $56 \mu \mathrm{g}$ $\mathrm{g}^{-1} \mathrm{MF}$ em clorofila, mostrando assim uma equivalência do teor pigmentar. Já o campo BI registrou 66,5 $\mu \mathrm{g} \mathrm{g}^{-1} \mathrm{MF}$ em clorofila. 


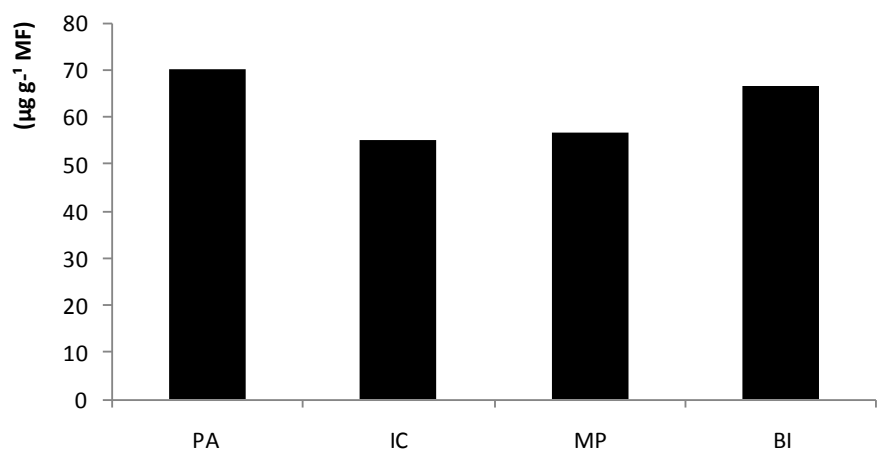

Figura 37: Concentração de clorofila a, extraída pelo solvente DMSO, no período do inverno de 2009, dos campos PA e IC correspondentes ao setor sul (Cananéia), MP (Mar Pequeno) e BI setor norte (Iguape).

Observa-se, entre o verão e o inverno de 2009, houve uma redução nos teores de clorofila. A média dos campos em Cananéia, no verão de 2009, foi de $74,7 \mu \mathrm{g} \mathrm{g}^{-1}$ em clorofila, enquanto que no inverno, este setor apresentou a média de 62,6 $\mu^{-1} \mathrm{~g}^{-1}$ de clorofila (MF). Para o setor norte, a média dos teores pigmentares dos campos foi $101,5 \mu \mathrm{g} \mathrm{g}^{-1} \mathrm{MF}$ em clorofila a no verão e para 0 inverno foi $61,5 \mu \mathrm{g} \mathrm{g}^{-1}$ em clorofila (MF).

No verão de 2010, o teor em clorofila a do campo PA foi $56,7 \mu \mathrm{g} \mathrm{g}^{-1} \mathrm{em}$ clorofila (MF) e no campo IC o valor encontrado foi $81,6 \mu \mathrm{g} \mathrm{g}^{-1}$ em clorofila (MF). Já o campo Bl apresentou $80,1 \mu \mathrm{g} \mathrm{g}^{-1}$ em clorofila (MF), praticamente a mesma quantidade de clorofila apresentada no campo IC que nesse verão tiveram um ligeiro aumento da quantificação pigmentar se comparados ao inverno de 2009 (Figura 38). 


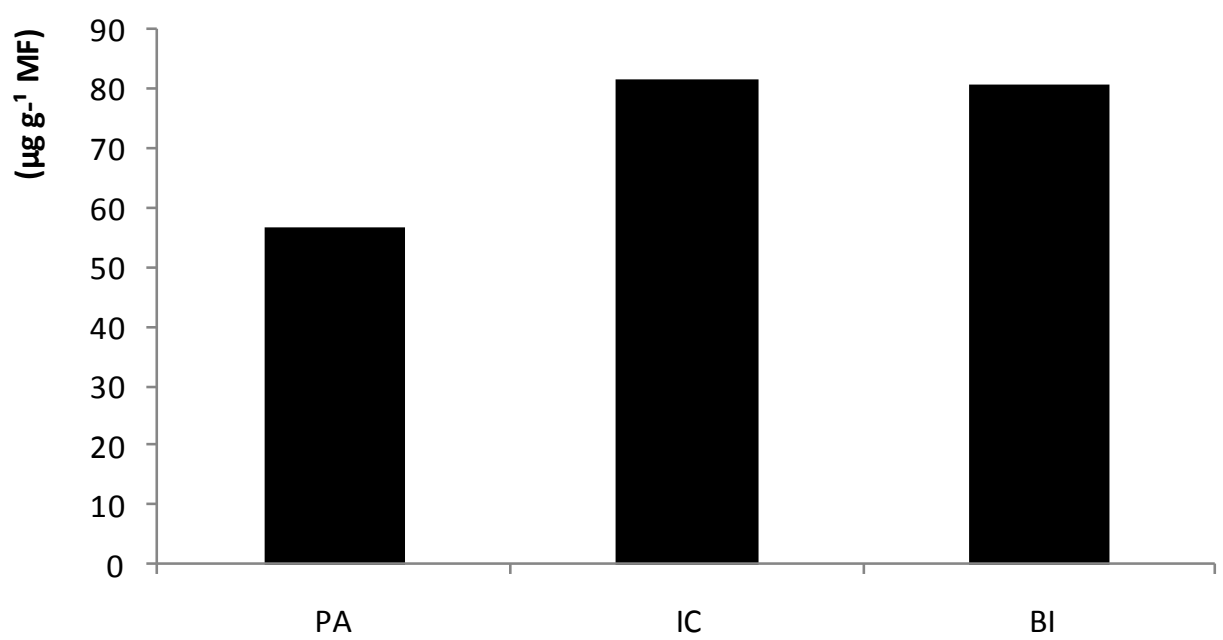

Figura 38: Distribuição da clorofila a, extraída pelo solvente DMSO, no período do verão de 2010, dos campos PA e IC correspondentes ao setor sul (Cananéia), BI no setor norte (lguape).

Os valores similares de clorofila a observados nos dois setores demonstram a necessidade da gramínea se adaptar ao ambiente, estando a gramínea exposta a variações de salinidade, níveis de nutrientes alterados, condições climáticas de temperatura e pluviosidade diferenciadas. Os valores analisados demonstram a capacidade do vegetal interagir com o ambiente em que se encontra, ou seja, adaptar-se às diferentes condições hidrogeológicas e sazonais, ou seja, em período de crescimento (verão) os teores clorofílicos aumentam enquanto no inverno, eles reduzem mostrando assim, a correlação do teor pigmentar em clorofila a com a variação climática e fisiologia da planta.

Segundo Maricle et. al. (2009), é importante ressaltar que espécies de marisma têm folhas grossas com sulcos muito pronunciados no lado adaxial e estômatos localizados quase que exclusivamente na superfície adaxial das folhas. Estas espécies também têm a cutícula mais espessa na região abaxial do que no lado adaxial de folhas, e a absorção de $\mathrm{CO}_{2}$ durante a fotossíntese é restrita à superfície foliar adaxial. Esse aspecto mostra que as quantificações pigmentares dependem das características dos espécimes de $S$. alterniflora que apresentam diferenças de tamanho e da cutinização de folhas jovens e adultas. 


\subsection{Avaliação de Proteína Solúvel Total em Spartina alterniflora}

Os teores de proteína solúvel total foram determinados nos períodos de inverno de 2009 (Figura 39) e verão de 2010 (Figura 40).

No inverno, os teores de proteina (MF) foram $7,17 \mathrm{mg} \mathrm{g}^{-1}$ no campo PA, $6,24 \mathrm{mg} \mathrm{g}^{-1}$ no campo IC. Enquanto no setor norte, os campos de Iguape apresentaram os teores de $5,7 \mathrm{mg} \mathrm{g}^{-1}$ no campo MP e 7,22 $\mathrm{mg} \mathrm{g}^{-1}$ no campo BI (Figura 39).



Figura 39: Distribuição das concentrações de proteína solúvel total ( $\mathrm{mg} \mathrm{g}^{-1} \mathrm{MF}$ ) no período de inverno de 2009, dos campos PA e IC correspondentes ao setor sul (Cananéia), $\mathrm{MP}$ e BI no setor norte (Iguape).

No período de verão 2010 , os teores de proteína solúvel total tiveram um ligeiro decréscimo. No campo PA foi quantificado $5,58 \mathrm{mg} \mathrm{g}^{-1} \mathrm{em} \mathrm{MF}$ e no campo IC, foi $5,12 \mathrm{mg} \mathrm{g}^{-1}$. Já o setor norte que somente foi amostrado o campo BI, mostrou valor de $5,48 \mathrm{mg} \mathrm{g}^{-1}$.

Gallagher et al. (1984) observaram, no estuário da Georgia, que no período do inverno houve redução do percentual de proteína na biomassa seca e no verão o contrario diferença devida ao perído de crescimento da $S$. alterniflora. 
A quantificação de proteína solúvel total deveria mostrar a adaptação do vegetal ao ambiente o qual, embora venha sofrendo alterações ambientais à longo prazo, não mostrou reflexo junto ás determinações do "pool" de protéinas totais, mas talvez isto exista ao nivel da expressão enzimática.

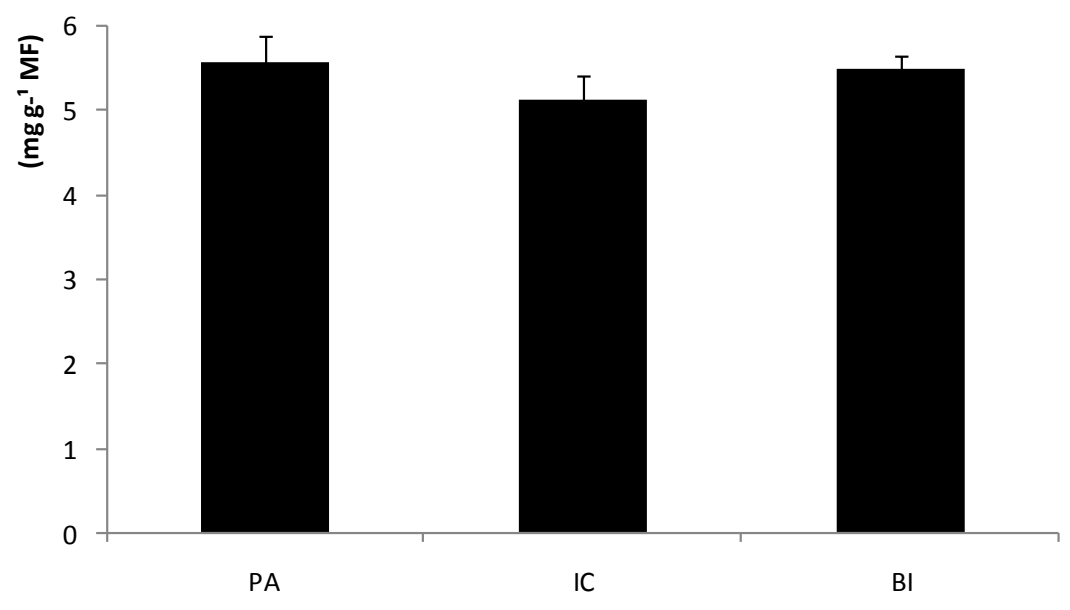

Figura 40: Distribuição das concentrações teores de proteína solúvel total ( $\mathrm{mg} \mathrm{g}^{-1} \mathrm{MF}$ ) em MF no período de verão de 2010, dos campos PA e IC correspondentes ao setor sul (Cananéia) e Bl ao norte (lguape).

\section{Discussão integrada}

A necessidade de uma discussão integrada dos parâmetros avaliados contemplando as variáveis climáticas, hídricas, sedimentológicas e biológicas, se faz necessária para a formação de um diagnóstico final. Assim, procurou-se correlacionar os principais parâmetros na dimensão de cada matriz. Dessa forma, uma análise estatística realizada para a matriz água foi determinante de modo a correlacionar os principais parâmetros que regem o sistema hídrico do $\mathrm{CELCl} \mathrm{e}$ seu reflexo nos campos de $S$. alterniflora.

Segundo Ayres et al. (2005), quando se gera uma matriz de correlação de componentes principais, o objetivo é indicar a significância relativa de variáveis 
preditivas, quando o número delas em um conjunto de dados, é muito grande. Pela análise de regressão múltipla podem surgir coeficientes irracionais, dificultando uma acurada identificação da importância daquelas variáveis. Tratase, portanto, de um teste interpretativo.

A matriz de correlação de componentes principais para a água foi gerada a partir dos parâmetros, temperatura, salinidade, Oxigênio Dissolvido, pH, Material Particulado em Suspensão (MPS), percentual de matéria orgânica no particulado (\%MOS), silicato, fosfato, clorofila a e feofitina (Tab. 14). Nesta matriz pode-se observar (em negrito) correlações significativas entre alguns parâmetros como a temperatura e o oxigênio, salinidade e $\mathrm{pH}$, salinidade com fosfato e silicato, $\mathrm{pH}$ com fosfato e silicato, o silicato e fosfato, e clorofila e feofitina.

Tabela 14. Matriz de correlação de componentes principais, parâmetros hidroquímicos: temperatura, salinidade, oxigênio dissolvido, $\mathrm{pH}$, material particulado em suspensão, \% matéria orgânica no particulado, silicato, fosfato, clorofila-a e feopigmento.

\begin{tabular}{|c|c|c|c|c|c|c|c|c|c|c|}
\hline Matriz de Correlação & Temp & Sal & OD & $\mathrm{pH}$ & MPS & $\%$ MOS & Silicato & Fosfato & $\mathrm{Cl}-\mathrm{a}$ & Feo \\
\hline Temp & 1 & & & & & & & & & \\
\hline Sal & 0.1281 & 1 & & & & & & & & \\
\hline OD & -0.767 & 0.0125 & 1 & & & & & & & \\
\hline $\mathrm{pH}$ & -0.0037 & 0.9457 & 0.165 & 1 & & & & & & \\
\hline MPS & 0.3604 & 0.0318 & -0.2312 & 0.0587 & 1 & & & & & \\
\hline$\%$ MOS & 0.434 & -0.0095 & -0.3541 & -0.0485 & 0.5886 & 1 & & & & \\
\hline Silicato & -0.1299 & -0.8559 & 0.0276 & -0.8302 & -0.1095 & -0.1988 & 1 & & & \\
\hline Fosfato & -0.2914 & -0.8135 & 0.2195 & -0.756 & -0.1647 & -0.1871 & 0.7892 & 1 & & \\
\hline $\mathrm{Cl}-\mathrm{a}$ & 0.2724 & 0.2619 & -0.2355 & 0.2858 & 0.2003 & 0.0238 & -0.2948 & -0.1727 & 1 & \\
\hline Feo & 0.0991 & 0.2144 & -0.1268 & 0.2324 & 0.0832 & -0.115 & -0.2072 & -0.0175 & 0.9063 & 1 \\
\hline
\end{tabular}

Após utilizar essa matriz de componentes principais para verificar os parâmetros que mais se correlacionam no sistema hídrico, para evidenciar estatisticamente, as diferenças entre as regiões sul, Cananéia, e norte, Iguape e entre os períodos estudados, foi gerado um gráfico de similaridade pelas distâncias euclidianas (MDS), a partir destes dados hídricos normalizados em log $(\mathrm{X}+1)$ da água de superfície (Figura 41).

Observam seis grupos que foram identificados pelo setor e período de estudo. Os grupos do lado esquerdo do MDS representam o setor sul, Cananéia em seus diferentes períodos. No grupo (a) encontram-se os resultados dos 
parâmetros hídricos agrupados no inverno de 2009, abaixo em (b) representa Cananéia no verão de 2010 e em (c) temos o verão de 2009. Nota-se alguns pontos fora dos grupos discriminados, como o identificado como PA-V9 que é o campo da Ponta do Arrozal onde alguns dos parâmetros hídricos destoam um pouco das característica do corpo hídrico principal.

Do lado direito do MDS, os grupos representam Iguape em seus diferentes períodos, (a) encontram-se os parâmetros hídricos agrupados do inverno de 2009, em (b) representa o verão de 2010 e em (c) encontra-se o verão de 2009 de Iguape. Nota-se também, neste lado do MDS, grupos que apresentam pontos distantes, como o BI-V9 que representa o banco de Spartina alterniflora em Iguape no verão de 2009.

Nesse agrupamento também é possível verificar a diferença sazonal dos parâmetros hídricos do sistema, onde os grupos superiores mostram características similares para o período de inverno de 2009, os grupos intermediários representam o verão de 2010 e os dois inferiores, o período do verão de 2009. Os períodos do inverno de 2009 e verão de 2010 apresentam características mais próximas em cada grupo. Enquanto, o verão de 2009 apresenta pontos mais distantes mostrando assim, que o verão é um período de grandes influências no corpo hídrico, tanto para Cananéia (c- esquerda) quanto para Iguape (c-direita). 


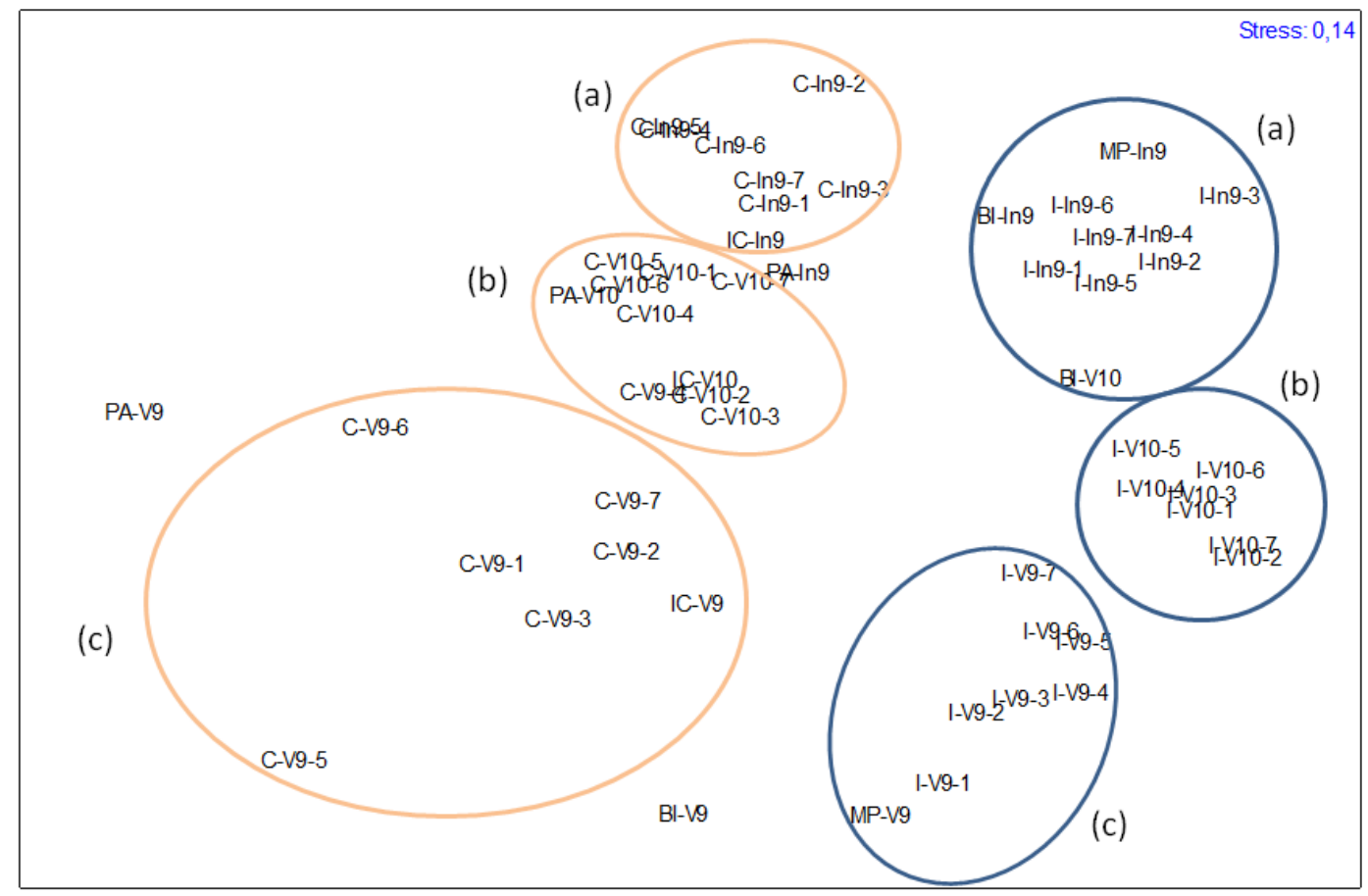

Figura 41. Gráfico de similaridade pelas distâncias euclidianas a partir destes dados hídricos normalizados em log $(X+1)$ da água de superfície. Grupos à esquerda referentes a Cananéia (C-x-y; PA-x, IC-x) e grupos à direita referentes a lguape (I-x-y; MP-x; BI-x). 


\section{CONCLUSÃO}

- As características físicas e químicas mais as tróficas do corpo hídrico do Complexo Estuarino-Lagunar Cananéia-Iguape mostraram diferenças evidentes entre os setores norte e sul. Cananéia apresentou condições de um sistema com misturas de água salobra e marinha, com níveis de oxigênio, $\mathrm{pH}$ e teores de silicato e fosfato que expressam condições de preservação e interferência antrópica baixa, porém sutilmente vem sofrendo a influência de sua ligação com o setor norte do CELCl. A região de Iguape, no setor norte, suporta o grande aporte de água doce e material terrestre escoado via Valo Grande que aporta neste sistema, reduzindo a salinidade e elevando os teores de silicato, fosfato, a turbidez e o material particulado em suspensão. O setor norte sustenta forte afluxo fluvial e as condições de mistura são fracamente moldadas pela maré diferentemente do que acontece em Cananéia. Desta forma, a região de Iguape é amplamente influenciada pelo canal artificial do Valo Grande.

- A Spartina alterniflora é condicionada pelas variações climáticas e pelo movimento da maré, ora em baixamar está exposta e em contato com a atmosfera, ora em preamar está submersa inundada pela água do corpo hídrico. Logo, a composição da água que circula no copo hídrico principal chega aos campos da gramínea, os quais atuam ora como importadores de material e ora como exportadores. As condições da água do entorno dos campos de Spartina alterniflora apresentaram certa correspondência com a água do corpo hídrico principal dependendo da oscilação da maré que, em estofa de baixamar e de preamar apresentaram equivalência dos parâmetros trabalhados e quando, em maré enchente ou vazante apresentaram alguns parâmetros como o MPS, silicato e fosfato que diferiram do comportamento da água superficial do canal principal. Destacam-se os campos da Ponta do Arrozal (ao sul) e da Barra do Icapara (ao norte) por apresentarem as maiores diferenças entre a água adjacente e a água do corpo hídrico de cada setor o que deve estar ligado às condições geomorfológicas uma vez que, o campo PA possui condições propícias à chegada suave da maré e localiza-se numa área extensa e próxima à desembocadura da 
Barra de Cananéia, enquanto o campo BI está próximo à Barra do Icapara e sofre bruscamente com a chegada da maré.

- $\quad$ Os campos de $S$. alterniflora do setor sul apresentaram-se mais preservados que o setor norte face às condições hídricas e geomorfológicas diferenciadas. Em Cananéia os campos PA e IC são banhados por água salobra e marinha, encontram-se em áreas de baixa hidrodinâmica e em equilíbrio sedimentar. No setor norte, em Iguape circula praticamente água doce, o campo MP está numa área de baixa hidrodinâmica, porém suscetível à erosão. Já o campo $\mathrm{BI}$ está numa área de alta hidrodinâmica, próximo a desembocadura norte do CELCI e numa zona em desequilíbrio sedimentar e com forte erosão.

- A Spartina alterniflora apresentou-se nas formas: baixa, média e alta, havendo indivíduos nas três faixas de altura nos dois setores e nos três períodos estudados. O maior desenvolvimento da gramínea foi no período de verão e neste período também foi observado o florescimento. As maiores alturas da gramínea foram registradas nos dois verões estudados, corroborando com outros estudos, o que está em acordo com o seu período de desenvolvimento e crescimento, embora tenha apresentado brotos e indivíduos baixos, tanto no verão quanto no inverno, mostrando assim o seu crescimento vegetativo.

- $\quad$ Os elementos $\mathrm{K}, \mathrm{Ca}, \mathrm{Fe}, \mathrm{Zn}$ e $\mathrm{Cr}$ foram determinados pela técnica instrumental de Análise por Ativação Neutrônica (AAN) que é uma técnica não destrutiva de medição de compostos químicos, que preenche dois requisitos básicos, a especificidade que é a habilidade de correlacionar diretamente e de forma não ambígua o sinal obtido com o elemento procurado, e a seletividade, que vem a ser a possibilidade de medir o elemento em questão na presença de outros elementos que emitem sinais da mesma natureza. A S. alterniflora concentrou os macro-elementos $\mathrm{K}$ e Ca principalmente na região do caule e folhas, mostrando assim, a participação na composição de sua estrutura aérea. Já os elementos Fe, $\mathrm{Zn}$ e $\mathrm{Cr}$ tiveram a maior concentração na parte radicular da planta, mostrando assim, que o compartimento subterrâneo da gramínea, as raízes e rizóides apresentam elevada interação química com o sedimento favorecidas pelas características do sedimento e do sistema radicular em forma de cabeleira que 
geram uma zona química singular de interação durante o ciclo de inundação e exposição da gramínea à maré. A concentração desses elementos na $S$. alterniflora não mostrou respostas sensíveis às alterações ambientais que os setores norte e sul do CELCI estão sujeitos. Provavelmente, esses elementos, nos valores observados devem ainda estar disponíveis em concentrações saudáveis nos compartimentos hídricos e sedimentar de cada local.

- $\quad$ Os metais pesados $\mathrm{Pb}, \mathrm{Cd}$ e $\mathrm{Hg}$ também apresentaram as maiores concentrações no sistema subterrâneo da $S$. alterniflora que mostrou a capacidade de super-concentrar metais pesados na raiz. O comportamento desses elementos permitiu a verificação da diferença da biodisponibilidade de metais que os setores norte e sul do CELCl estão sujeitos. Iguape apresentou as maiores concentrações desses metais nas raízes da Spartina, principalmente o chumbo. A região, que historicamente foi acometida pela mineração, ainda sofre as conseqüências dessa atividade e nesse trabalho pode ser verificado, por meio de estudo em uma matriz vegetal, que a disponibilidade de metais pesados continua ocorrendo em Iguape aumentando a susceptibilidade do sistema.

- A Spartina alterniflora mostrou seu comportamento fisiológico natural diante das concentrações dos diversos elementos encontrados em seu sistema aéreo e subterrâneo. Ela apresentou o desenvolvimento e florescimento considerado adequado aos períodos sazonais estudados e seu trabalho como bioindicadora de alterações ambientais respondeu às necessidades de diferenciar os diferentes graus de impacto antrópico nos setores norte e sul do Complexo Estuarino-Lagunar de Cananéia-Iguape, evidenciando, nas respostas, sobretudo do sistema radicular e nas características ecológicas de seus campos como distribuição e densidade. Por ser uma produtora primária, fixa, perene, halófita, de fácil adaptação, acomodação e crescimento em sedimentos inconsolidados e colonizadora de ambientes húmidos de marismas e mangues é uma potencial biomonitora para o estudo de acúmulo de metais em estuários, sendo necessária a restrição de seu uso em sistemas onde a salinidade atinge valores dulcícolas, inviabilizando o estabelecimento de seus campos. 


\section{REFERÊNCIAS BIBLIOGRÁFICAS}

ADAIME, R. R. 1978. Estudo da Variação estacional do "standing-crop" e do repovoamento em um banco de Spartina alterniflora Loiseleur, 1807, no Complexo Estuarino-Lagunar de Cananéia. Boletim do Instituto Oceanográfico, São Paulo, 27 (2): 1-43.

ALBERTS, J. J.; PRICE, M. T. \& KANIA, M. 1990. Metal Concentrations in Tissues of Spartina alterniflora (Loisel.) and Sediments of Georgia Salt Marshes. Estuarine, Coastal and Shelf Science. 30:47-58.

AMINOT, A. \& CHAUSSEPIED, M. 1983. Manuel des analyses chimiques em milieu marin. CNEXO. p. 63-73.

ARNON, D. I. 1949. Copper enzymes in isolated chloroplasts. Polyphenoloxidase in Beta vulgaris. Plant Physiology. V. 24, p. 1-15.

AYRES, MANUEL; AYRES JR., M; AYRES, D. L., DOS SANTOS, A. A. 2005. BioEstat: Aplicações estatísticas nas áreas das ciências biomédicas. Belém, Pará-Brasil.

BARNES, J. D.; BALAGUER, L.; MANRIQUE, E.; ELVIRA, S.; DAVISON, A. W. 1992. A reappraisal of the use of DMSO for the extraction and determination of chorophylls $a$ and $b$ in lichens and higher plants. Environmental and Experimental Botany, 32: 85-100.

BARRERA-ALBA, J. J.; GIANESELLA, S. M. F.; SALDANHA-CORREA, F. M. P.\& MOSER, G. A. O. 2007. Influence of an Artificial Channel in a Well-Preserved SubTropical Estuary. Journal of Coastal Research, SI 50 (Proceedings of the 9th International Coastal Symposium), 1137 - 1141. Gold Coast, Australia

BARROSO, G.F. 1998. BMLP - Programa Brasileiro de Intercâmbio em Maricultura. Programa de Monitoramento Ambiental. Protocolo para Análise de clorofila a e feopigmentos pelo método fluorímétro TD- 700. Vitória, Espírito Santo, p.1-21.

BASTOS, E. O.; PERAZZOLO, M.; BAPTISTA, J. M. R. 1993a. Variação do número de estômatos e micropêlos em Paspalum vaginatum $\mathrm{Sw}$. em relação às condições abióticas numa marisma do estuário da Lagoa dos Patos, RS-Brasil. Acta Botanica Brasilica (S Paulo). 6(2):105-117. 
BASTOS, E. O.; PERAZZOLO, M.; GORGEN, A. U. G. 1993b. Ocorrência e estrutura de glândulas de sal em espécies halófitas no município do Rio Grande, RS. Iheringia, Série Botânica. Porto Alegre 43:3-14

BONETTI FILHO, J. \& MIRANDA, L. B. de. 1997. Estimativa da descarga de água doce no sistema estuarino-lagunar de Cananéia-Iguape. Revista Brasileira de Oceanografia, IOUSP, São Paulo, 45(1/2): 89-94.

BRADFORD, M. M. 1976, Rapid and sensitive method for the quantitation of microgram quantities of protein utilizing the principle of protein-dye binding, Analytical Biochemistry. 72: 248-254

BRAGA, E. S. \& CHIOZZINI, V. G. 2008. Nutrientes dissolvidos no Complexo EstuarinoLagunar de Cananéia-Iguape: Influência do Valo Grande no setor sul (1992 e 2005). Simpósio Brasileiro de Oceanografia. Instituto Oceanográfico. São Paulo.

BRAGA, E. S. 1995. Nutrientes dissolvidos e produção primária do fitoplâncton em 2 sistemas costeiros do Estado de São Paulo. Tese Doutorado, IOUSP, 2vols.

BRAGA, E. S. 2002. Bioquímica Marinha e efeitos da poluição nos processos bioquímicos. São Paulo: Ed., FUNDESPA (2d), 93p.

BRAGA, E. S., 1995. Nutrientes dissolvidos e produção primária do fitoplâncton em dois sistemas costeiros do Estado de São Paulo. Tese de Doutorado. Instituto Oceanográfico. Universidade de São Paulo. 2v.

BRITO, I. C. 1983. A importância dos bioindicadores vegetais no ambiente aéreo, aquático e terrestre: plantas indicadoras do mercúrio. In: Congresso Nacional de Botânica, 34. Porto Alegre. Anais. Porto Alegre: SBB/UFRGS, 1983. v.1, p. 115119.

BURKE, D. J.; WEIS, J. S.; WEIS, P. 2000. Release of metals by the leaves of the salt marsh grasses Spartina alterniflora and Phragmites australis. Estuarine Coastal Shelf Science. 51:153-9.

CAÇADOR, I.; VALE, C.; CATARINO, F. 1996. The influence of plants on concentration and fractionation of $\mathrm{Zn}, \mathrm{Pb}$, and $\mathrm{Cu}$ in salt marsh sediments (Tagus estuary, Portugal). Journal of Aquatic Ecosystem Health. 5:193 -198. 
CAÇADOR, I.; VALE, C.; CATARINO, F. 2000. Seasonal variation of $\mathrm{Zn}, \mathrm{Pb}, \mathrm{Cu}$ and $\mathrm{Cd}$ concentrations in the root-sediment system of Spartina maritima and Halimone portulacoides from Tagus estuary salt marshes. Marine Environmental Research 49:279- 90.

CAETANO, M.; VALE, C.; CESÁRIO, R. \& FONSECA, N. 2008. Evidence for preferential depths of metal retention in roots of salt marsh plants. Science of Total Environment. 390: 466 - 474.

CAMARGO, M. G. 2006. SysGran: um sistema de código aberto para análises granulométricas do sedimento. Revista Brasileira de Geociências, vol. 36(2): 371378.

CHIOZZINI, V. G.; MALUF, J. C. C.; TORRES, J. L. R. \& BRAGA, E. S. 2008 Variabilidade sazonal (inverno-verão) das especiações químicas de nitrogênio no Complexo Estuarino-Lagunar de Cananéia - SP. Simpósio Brasileiro de Oceanografia. Instituto Oceanográfico. São Paulo.

CINTRÓN, G. \& SCHAEFFER-NOVELLI, Y., 1983. Introduccion a la ecologia Del manglar. Montevideo, ROSTLAC, Unesco, 109p.

CONAMA. 2005. Conselho Nacional do Meio Ambiente (CONAMA) - resolução 357 de 15 de março de 2005. 23p.

COSTA, C. S. B. \& DAVY, A. J. 1992. Coastal saltmarsh communities of Latin America. In: U. Seeliger (ed.), Coastal Plant Communities of Latin America. San Diego, California, Academic Press, Inc, Cap. 12: 179-199.

COSTA, C. S. B. \& MARANGONI, J. C. 1997. Criação de marismas com espécies nativas: Experimento piloto no sul do Brasil. VII COLACMAR, Congresso LatinoAmericano sobre Ciências do Mar, Volume 1.

COSTA, C. S. B. 1998. Plantas de Marismas e Terras Alagáveis. In: Os ecossistemas costeiro e marinho do extremo sul do Brasil. Ed. Seeliger, U., Odebrecht, C., Castello, J. P. Rio Grande: Ecoscientia. 341p.

COSTA, C. S. B. 1998. Production ecology of Scirpus maritimus in southern Brazil. Ciência Cultura. São Paulo. 50p. 
CRUZ, A. C. F. et al. 2007. Métodos Comparativos na Extração de Pigmentos Foliares de Três Híbridos de Bixa orellana L. Revista Brasileira de Biociências, Porto Alegre, v. 5, supl. 2, p. 777-779.

CUNHA, F. G. 2003. Contaminação humana e ambiental por chumbo no Vale do Ribeira nos Estados de São Paulo e Paraná. Tese de doutorado, Departamento de Geologia e Recursos Naturais, UNICAMP.

CUNHA, S. R. 1994. Modelo ecológico das marismas de Spartina alterniflora Loisel (Poaceae) do estuário da Lagoa dos Patos, RS. Tese de Mestrado, Universidade de Rio Grande, Brasil.

CUNHA-LIGNON, M. et al. 2009. Analysis of mangrove forest succession, using sediment cores: a case study in the cananéia -iguape coastal system, São PauloBrazil. Brazilian Journal of Oceanography, 57(3):161-174.

DAEE. 1989. Estudo de impacto ambiental das obras complementares da barragem do Valo Grande. Relatório final, 2v.

DAVY, A. J.; COSTA, C. S. B. 1992. Development and organization of salt marsh communities. In: Seeliger U (ed) Coastal plant communities of Latin America. Academic Press, New York, pp 157-178

DAY, J. W.; JR, H. C.; KEMP, W. M.; YÁÑEZ-ARANCIBIA, A.; DEEGAN, L. A. 1989. Nekton, the free swimming consumers. In: Day JW Jr, Hall CAS, Kemp WM, Yáñez-Arancibia A (eds) Estuarine Ecology. Wiley-Interscience Publ. pp 377-437.

DE SOETE, D.; GIJELS, R.; HOSTE, J. Neutron activation analysis, London, WileyInterscience, 1972

DIEGUES, ANTONIO CARLOS. 2007. O Vale do Ribeira e Litoral de São Paulo: meioambiente, história e população. Universidade de São Paulo.

DORGELO, J.; MEESTER, H.; VANVELZEN, C. 1995. Effects of diet and heavy metals on growth rate and fertility in the deposit-feeding snail Potamopyrgus jenkinsi. Hydrobiologia. 315:199-210.

DOYLE, M. O.; OTTE, M.L. 1997. Organism-induced accumulation of iron, zinc and arsenic in wetland soils. Environment Pollution. 96:1-11. 
DRIFMEYER, J. E. \& REDD, B. 1981. Geographic Variability in Trace Element Levels in Spartina alterniflora. Estuarine, Coastal and Shelf Science. 13: 709-716.

FERNANDES, MANLIO SILVESTRE. 2006. NUTRIÇÃO MINERAL DE PLANTAS. Editora Independente. p: 432

FIGUEROA, M. E.; MARTOS, M. J.; FERNANDEZ-PALACIOS, J. M.; GARCIA, J. C. R. 1985. Papel geomorfológico de Spartina maritima (Curtis) Fernald y Spartina densiflora Brong. en las marismas del Río Odiel. Anais la Reunião Quartenário Ibérico, Lisboa, pp 367-378

FITZGERALD, E. J.; CAFFREY, J. M.; NESARATNAM, S. T.; MCLOUGHLIN, P. 2003. Copper and lead concentrations in salt marsh plants on the Suir Estuary, Ireland. Environment Pollution. 123:67- 74.

FLYNN, M. N.; TARARAM, A. S.; WAKABARA, Y. 1996. Effects of habitat complexity on the structure of macrobenthic association in a Spartina altemiflora marsh. Revista Brasileira de Oceanografia. 44 (1):9-21.

FOLK R.L. \& WARD W.C. 1957. Brazos River bar: a study in the significance of grain size parameters. Journal of Sedimentary Petrology, .27:3-26.

FREITAS, R. C.; BARCELLOS, R. L.; PISETTA, M.; RODRIGUES, M. \& FURTADO, V. V. 2008. O canal do Valo Grande e o assoreamento no Sistema Estuarino-Lagunar de Cananéia-Iguape, Estado de São Paulo, Brasil. Simpósio Brasileiro de Oceanografia. Instituto Oceanográfico. São Paulo.

GALLAGHER, J. L.; WOLF, P. L.; PFEIFFER, W. J. 1984. Rhizome and Root Growth Rates and Cycles in Protein and Carbohydrate Concentrations in Georgia Spartina alterniflora Loisel. American Journal of Botany. Vol. 71, n. 2, p. 165-169.

GARRY, M. \& RAND, P. D. 1995. Fundamentals of Aquatic Toxicology, "Efects, Environmental Fate and Risk assessment", 2a Edition.

GEOBRÁS. 1966. Complexo Valo Grande- Mar Pequeno- Rio Ribeira de Iguape. Relatório para o serviço do Vale do Ribeira-DAEE, São Paulo, 2vols 
GLEASON, M. L.; DRIFMEYER, J. E.; ZIEMAN, J. C. 1979. Seasonal and environmental variation in $\mathrm{Mn}, \mathrm{Fe}, \mathrm{Cu}$ and $\mathrm{Zn}$ content of Spartina alterniflora. Aquatic Botany. 7:385-92.

GRANT, C. A.; BUCKLEY, W. T.; BAILEY, L. D. \& SELLES, F. 1998. Cadmium accumulation in crops. Canadian Journal of Plant Science, 78:1-17.

GRASSHOFF, K., KREMLING, K. \& EHRHARDT, M. 1983. Methods of Seawater Analysis. 3 ed. Florida: Verlage Chemie: 417 p.

GRIMME, L. H.; PORRA, R. J.; PYLIOTIS, N. A.; THORNE, S. W.; ARGUROUDIAKOYUNOGLOU, J.; AKOYUNOGLOU, G. 1974. Characteristics of the orange, chlorophyll-deficient Chlorella fusca and observations during its regreening and rearrangement of the photosynthetic apparatus. Portugal Acta Biologica. Ser. A 14:153-164.

GROSS, M. F.; V. KLEMAS, J. E. 1986. Biomass and Structure of a Spartina alterniflora Loisel.-Dominated Salt Marsh in France Levasseur Source: Bulletin of the Torrey Botanical Club, v.113, 2, p. 125-130.

HARPER, D., 1995. Eutophication of Freshwaters: Principles, problems and restoration. Chapman \& Hall, London, 327p.

HART, J. J.; WELCH, R. M.; NORVELL, W. A.; SULLIVAN, L. A. \& KOCHIAN, L. V. 1998. Characterization of cadmium binding, uptake, and translocation in intact seedlings of bread and durum wheat cultivars. Plant Physiology, 116:1413-1420.

HEMPEL, M.; BOTTÉ, S. E.; NEGRIN, V. L. \& CHIARELLO, M. N. \& MARCOVECCHIO, J. E.2008. The role of the smooth cordgrass Spartina alterniflora and associated sediments in the heavy metal biogeochemical cycle within Bahía Blanca estuary salt marshes. Journal of Soils and Sediments. 8:289-297

HISCOX, J. D.; ISRAELSTAM , G. F. 1979. A method for the extraction of chlorophyll from leaf tissue without maceration. Canadian Journal of Botany. 57, 1332-1334.

JEFFREY, S. W. \& HUMPHREY, G. F. 1975. New spectrophotometric equations for determining chlorophylls $\mathrm{a}, \mathrm{b} . \mathrm{c}_{1}$ and $\mathrm{c}_{2}$ in higher plants, algae and natural phytoplankton. Biochemie und Physiologie der Pflanzen, Bd. 167, S. 191-194 p. 
KÜPPER, H.; MIJOVILOVICH, A.; MEYERKLAUCKE, W.; KRONECK, M.H. 2004. Tissue and age-dependent differences in the complexation of cadmium and zinc in the cadmium/zinc hyperaccumulator Thlaspi caerulescens (Ganges Ecotype) revealed by Xray absorption spectroscopy. Plant Physiology, v.134, 748-757.

KURDZIEL, B .M.; PRASAD, M. N. V.; STRZALKA, K. 2004. Photosynthesis in heavy metal stressed plants. In: PRASAD, M.N.V. Heavy metal stress in plants: From biomolecules to ecosystems. 2nd ed. Springer, printed in India, 2004. p.146-181.

LACERDA, L. D.; CARVALHO, C.; TANIZAKI, K.; OVALLE, A.; REZENDE, C. 1993. The biogeochemistry and trace metals distribution of mangrove rhizospheres. Biotropica. 25:252- 7 .

LACERDA, L. D.; FREIXO, J. L.; COELHO, S. M. 1997. The effect of Spartina alterniflora Loisel on trace metals accumulation in intertidal sediments. Mangroves Salt Marshes. v1:201-9.

MAHIQUES, M. M. et al. 2009. Anthropogenic influences in a lagoonal environment: a multiproxy approach at the Valo Grande mouth, Cananéia-Iguape system (SE Brazil). Brazilian Journal of Oceanography, 57(4):325-337.

MALAVOLTA, EURIPEDES. 2006. Manual de Nutrição Mineral de Plantas. Editora: Ceres. Edição: 1. Páginas: 631

MALUF, J. C. C. 2009. Estudo dos metais traço (Zinco, Cádmio e Chumbo) em duas regiões do complexo estuarino-lagunar de Cananéia-Iguape (SP) sob diferentes pressões antrópicas. Dissertação de mestrado, Instituto Oceanográfico, USP, $125 \mathrm{pp}$.

MARICLE, B. R. et al. 2009. Diversity in leaf anatomy, and stomatal distribution and conductance, between salt marsh and freshwater species in the C4 genus Spartina (Poaceae). New Phytologist. 184: 216-233

MARQUES-JUNIOR, A. N., MORAES, R. B. C., MAURAT, M. C. 2002. "Poluição Marinha". In: PEREIRA, R.C. \& SOARES-GOMES, A. Biologia Marinha. Rio de Janeiro. Interciência. 311-334. 
MAZON, A. F., PINHEIRO G. H. D., FERnANDES, M. N. 2000. Contaminação dos Ecossistemas aquáticos pelo cobre e risco potencial a biodiversidade: Estudo da Toxicidade do Cobre em Corimbatá, P. scrofa (Teleostei, Prochilodontidae). Ecotoxicologia: Perspectivas para o século XXI. São Carlos:RiMA. 327-342.

MENDELSSOHN, I. A.; POSTEK, M. T. 1982. Elemental analysis of deposits on the roots of Spartina alterniflora Loisel. American Journal of Botany. 69:904-12.

MENGEL, K.; KIRKBY, E. A. 1987. Principles of plant nutrition. 4. ed. Bern: International Potash Institute. $687 \mathrm{p}$.

MESQUITA, A. R. de \& HARARI, J. 1983. Tides and tide gauges of Cananéia and Ubatuba - Brazil (lat $24^{\circ}$ ). Relatório interno do Instituto Oceanográfico. Universidade de São Paulo, (11):1-14.

MIRANDA, L. B.; MESQUITA, A. R. \& FRANÇA, C. A. S. 1995. Estudo da circulação e dos processos de mistura no extremo sul do Mar de Cananéia: condições de dezembro de 1991. Boletim do Instituto Oceanográfico/USP, 43(2): 153-164.

MIYAO, S. Y. \& HARARI, J. 1989. Estudo preliminar da maré e das correntes de maré na região estuarina de Cananéia (25S-048"W). Boletim Instituto Oceanográfico, São Paulo, 37(2):107-123

MIYAO, S. Y.; NISHIHARA, L. \& SARTI, C. 1986. Características físicas e químicas do sistema estuarino-lagunar de Cananéia-Iguape. Boletim do Instituto Oceanográfico, São Paulo. 34 (único): 23-36.

MIYAO, S. Y.; NISHIHARAA, L.; SARTI, C. C. 1986. Características físicas e químicas do sistema estuarino-lagunar de Cananéia-Iguape. Boletim do Instituto Oceanográfico, São Paulo 34:23-26.

MROZEK, Jr. EDWARD. 1980. Effect of mercury and cadmium on germination of spartina alterniflora loisel seeds at various salinities. Environmental and Experimental Botany. Vol. 20, pp. 367 to 377

MURPHY, K. J. 2000. Predizendo alterações em ecossistemas aquáticos continentais e áreas alagáveis: o potencial de sistemas bioindicadores funcionais utilizando 
macrófitas aquáticas. Boletim da Sociedade Brasileira de Limnologia, Maringá, n. 27, p. 7-9.

NIPPER, M. G. 1990. "Problemas de Poluição em organismos Bentônicos”. II Simpósio de Ecossistemas na Costa Sul e Sudeste Brasileira. Estrutura, Função e Manejo. v.3, p. 24-42.

PELLENBARG, R. E. 1984. On Spartina alternifora Litter and The Trace Metal Biogeochemistry of a Salt Marsh. Estuarine, Coastal and Shelf Science. 18:331346.

PELLENBARG, R. E. 1985. Spartina alterniflora litter in salt marsh geochemistry. In: Marine and Estuarine Geochemistry - SIGLEO, A. C. \& HATTORI, A. (eds) Cap., 21: $305-313$

PISETTA, MARCELO. 2010. Análise do processo de distribuição do material particulado em suspensão e metais associados no sistema Cananéia-Iguape (SP). Tese apresentada ao Instituto Oceanográfico da Universidade de São Paulo.

POMEROY, L. R., WIEGERT, R. G., 1981. In: Pomeroy, L.R., Wiegert, R.G. (Eds.), Ecological Studies. The Ecology of Salt Marsh, 38. Springer, New York, pp. $137 \mathrm{e} 160$.

PRADO, RENATO DE MELLO. 2009. Nutrição de plantas. Editora: UNESP. Edição: 1. P. 408.

REBOREDA, R.; CAÇADOR, I.; PEDRO, S.; ALMEIDA, P. R. 2008. Mobility of metals in salt marsh sediments colonized by Spartina maritima (Tagus estuary, Portugal). Hydrobiologia. 606:129-137 review. Environmental Pollution, v.98, p.29- 36.

SCHAEFFER-NOVELLI, Y. \& CINTRÓN-MOLERO, G. 2000. Brazilian mangroves, management and conservation: Maracá, Caravelas and Cananéia case studies. In: Mangrove 2000: sustainable use of estuaries and mangrove: challenge and prospect.

SCHAEFFER-NOVELLI, Y.; MESQUITA, H. S. L.; CINTRÓN-MOLERO, G. The Cananéia Lagoon Estuarine System, São Paulo, Brazilian Estuaries. Vol. 13, No. 2, p. 193-203. 
SEZERINO, P. H. 2002. Utilização de biofiltros com macrófitas (vertical flow constructed wetlands) como pós-tratamento de lagoas de estabilização aplicadas aos dejetos de suínos. Dissertação de Mestrado em Engenharia Ambiental. Programa de Pósgraduação em Engenharia Ambiental, Universidade Federal de Santa Catarina, $123 p$.

SEZERINO, P. H. 2006. Potencialidade dos filtros plantados com macrófitas (Constructed Wetlands) no pós-tratamento de lagoas de estabilização sob condições de clima subtropical. Tese de Doutorado em Engenharia Ambiental, Universidade Federal de Santa Catarina, $171 \mathrm{p}$.

SHAEFER-NOVELLI, Y. 2005. Situação atual do grupo de ecossistemas: "manguezal, marisma e apicum" incluindo os principais vetores de pressão e as perspectivas para sua conservação e uso sustentável. São Paulo. Brasil

SHAW, B. P.; SAHU, S. K.; MISHRA, R. K. 2004. Heavy metal induced oxidative damage in terrestrial plants. In: PRASAD, M.N.V. (Ed.). Heavy metal stress in plants: From biomolecules to ecosystems. 2nd ed. Springer, printed in India. p.84126.

SILVA, C. P.; PEREIRA, C. M. P.; DORNELES, L. P. P. 1993. Espécies de gramíneas e crescimento de Spartina densiflora Brong. em uma marisma da Laguna dos Patos, RS, Brasil. Cad Pesq Ser Bot (Santa Cruz do Sul) 5(1):95-108

SILVA, J. F. 1989. Dados climatológicos de Cananéia e Ubatuba (Estado de São Paulo). Boletim Climatológico do Instituto Oceanográfico - USP, (6): 1-21 p.

STRICKLAND, J. D. H. \& PARSONS, T. R. 1968. A pratical handbook of seawater analysis. Bulletin of the Fisheries Research Board of Canada. 169: 1-311.

SUGUIO, K. \& TESSLER M. G. 1992. Depósitos quaternários da planície costeira de Cananéia-Iguape (SP). Publ. Esp. IOUSP, (9):1-33.

SUGUIO, K. 1973. Introdução à sedimentologia. São Paulo, Edgard Blücher \& Universidade de São Paulo. 317 p. 
SUNDBY, B.; VALE, C.; CACADOR, I.; CATARINO, F. 1998. Metal-rich concretions on the roots of salt marsh plants: mechanism and rate of formation. Limnology \& Oceanography. 43:245-52.

THOM, B. G. 1982. Mangrove Ecology - A geomorphological perspective. In: Mangrove ecosystems in Australia: Stucture, function and management. B. F. Clough (ed). Australian national University Press. Australia, 3-17

VAle, C.; CATARINO, F.; CORTESAO, C.; CACADOR, M. 1990. Presence of metalrich rhizoconcretions on the roots of Spartina maritima from the salt marshes of the Tagus estuary, Portugal. Science of Total Environment. 97/98:617- 26.

WALSH, G. E. 1990. Anatomy of the seed and seedling of Spartina alterniflora Lois. (Poaceae). Aquatic Botany. 38: 177-193.

WEIS, J. S. \& WEIS, P. 2004. Metal uptake, transport and release by wetland plants: implications for phytoremediation and restoration. Environment International. 30, 685-700.

WENTWORTH C.K. 1922.A scale of grade and class terms for clastic sediments. Journal of Geology, 30:377-392

WILLIAMS, T.P., J.M. BUBB AND J.N. LESTER. The occurrence and distribution of trace metals in halophytes. Chemosphere, Vol. 28, No. 6, pp. 1189-1199, 1994.

WINDHAM, L.; WEIS, J. S.; WEIS, P. 2001. Lead uptake, distribution, and effects in two dominant salt marsh macrophytes, Spartina alterniflora (cordgrass) and Phragmites australis (common reed). Marine Pollution Bulletin. 42:811 - 6 .

WINDHAM, L.; WEIS, J. S.; WEIS, P. 2001. Patterns and processes of mercury (Hg) release from leaves of two dominant salt marsh macrophytes, Phragmites australis and Spartina alterniflora. Estuaries. 24:787-95.

YAMAGATA, A. A. et al. Estruturação da Comunidade Macrobêntica da Marisma nas formas baixa e alta de Spartina alterniflora. Anais do VIII Congresso de Ecologia do Brasil, 23 a 28 de Setembro de 2007, Caxambu - MG. 